\title{
2015
}

\section{GLOBAL HUNGER INDEX}

ARMED CONFLICT AND THE CHALLENGE OF HUNGER

$-$

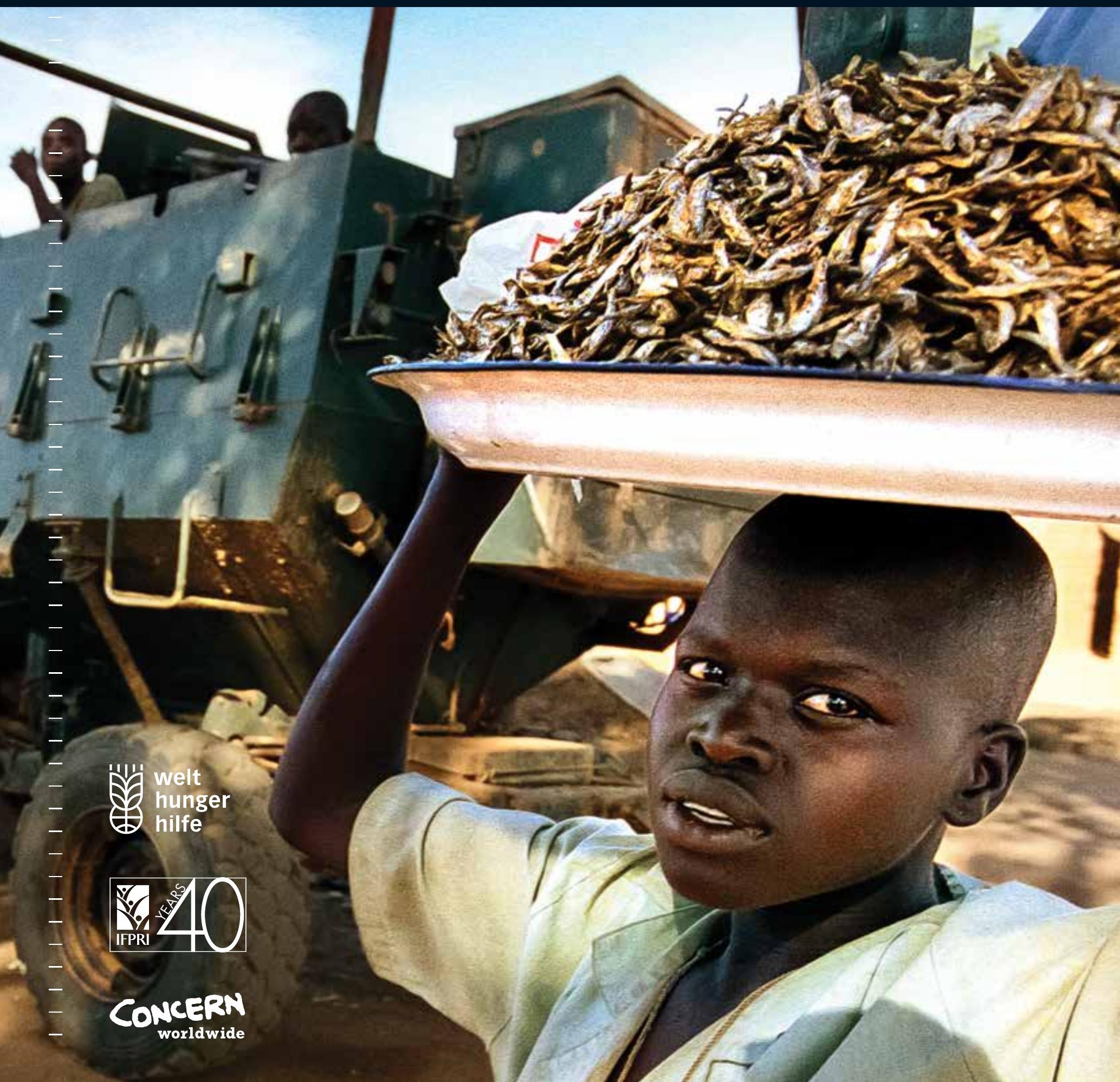




\section{5}

\section{GLOBAL HUNGER INDEX}

\section{ARMED CONFLICT AND THE CHALLENGE OF HUNGER}

International Food Policy Research Institute:

Klaus von Grebmer, Jill Bernstein, Nilam Prasai, Sandra Yin, Yisehac Yohannes

Concern Worldwide:

Olive Towey

Welthungerhilfe:

Andrea Sonntag, Larissa Neubauer

World Peace Foundation/Tufts University:

Alex de Waal

Bonn/Washington, DC/ Dublin

October 2015

Cover photo: A boy sells dried fish in a camp for internally displaced people in Uganda in 2003. The war with the Lord's Resistance Army (LRA) led many residents to leave their villages for the relative safety of towns and IDP camps. While violence associated with the LRA started in Uganda, it has since spilled over into the Democratic Republic of the Congo, Central African Republic, and South Sudan.
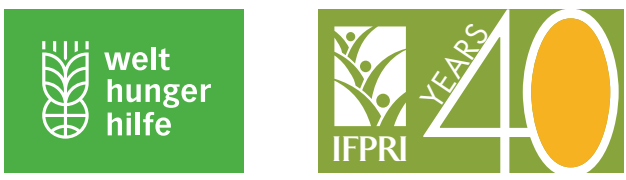
More than 13 million people were uprooted by violence in 2014 . Most left, propelled by conflicts in Syria, Afghanistan, and Somalia. An average of 42,500 people per day fled their homes in 2014. Approximately 59.5 million people are displaced by conflict and persecution worldwide, the highest level ever recorded.

Increasing numbers of people are being caught in a "conflict trap" that holds them in poverty. Today, displaced people spend an average of more than 17 years in camps or with host communities. Moreover, most of the more than 40 countries affected by internal conflict since 2000 had already suffered one or more civil wars over the previous three decades.

Conflict can have ripple effects on human welfare. Countries that suffer protracted or repeated violent conflict may experience much higher levels of undernutrition, reduced access to education, and much higher infant mortality than stable countries of similar economic standing.

The 2015 Global Hunger Index, jointly published by the International Food Policy Research Institute (IFPRI), Concern Worldwide, and Welthungerhilfe, shows that levels of hunger in the developing world have declined by more than one-quarter since 2000 . Despite the progress made, the level of hunger in the world remains unacceptably high, with 795 million people still going hungry, more than one in four children affected by stunting, and 9 percent of children affected by wasting.

This is the tenth year that IFPRI has calculated the Global Hunger Index (GHI) and analyzed this multidimensional measure of global hunger. The series of reports tracks the state of hunger worldwide and country by country, putting a spotlight on those regions and countries where action is most needed to address hunger.

Because the calculation of the $\mathrm{GHI}$ is limited by the data collected by governments and international agencies, this report does not fully reflect the impact of the latest events. We hope that governments and international agencies will enhance their cooperation and release more timely and complete data on hunger worldwide.
This year's report identifies the countries and regions where hunger is most severe and persistent. It shows that levels of hunger remain serious or alarming in 52 of the 117 countries with GHI scores. Among the world's regions, South Asia and Africa south of the Sahara continue to experience the highest levels of hunger.

The report also explores the relationship between armed conflict and hunger. This year's essay, authored by Alex de Waal, executive director of the World Peace Foundation and a research professor at Tufts University, sheds light on an unheralded achievement of the past 50 years. "Calamitous famines," which are famines that kill more than one million people, seem to have vanished. De Waal notes that even if the link between conflict and hunger is clear, due to the effectiveness of humanitarian responses in the modern world, conflict need not necessarily lead to the extreme hunger that is famine.

The Sustainable Development Goals (SDGs) signal a renewed commitment to end hunger and global poverty by 2030 . Under Goal 2, which is a call "to end hunger, achieve food security and improved nutrition, and promote sustainable agriculture," it will be critical to ensure that all people, in particular the poor and people in vulnerable situations, have access to sufficient and safe nutritious food all year round. More needs to be done to help people become more resilient and help them better withstand the consequences of armed conflict, as proposed in other SDGs. If the SDGs are to be more than aspirations, we need to find real and lasting solutions to conflict, tackle growing inequalities within and across borders, mitigate the effects of climate change, and eliminate the food insecurity that is most profoundly affecting the poorest places on the planet.

In the face of conflicts both new and old, we must intensify our fight against hunger. In this age of unprecedented mass displacement, a commensurate global response is needed to support those fleeing conflict and persecution. Looking ahead, the international community must make conflict prevention, mitigation, and resolution a much higher political priority.

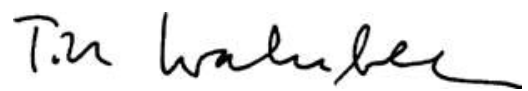

\section{Dr. Till Wahnbaeck}

Secretary General and

Chairperson

Welthungerhilfe

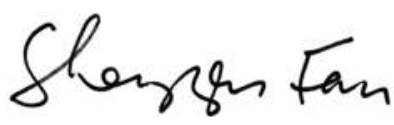

\author{
Dr. Shenggen Fan \\ Director General \\ International Food Policy \\ Research Institute
}

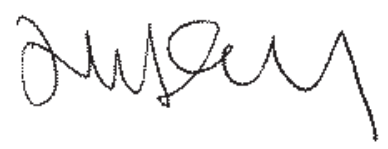

Dominic MacSorley

Chief Executive

Concern Worldwide 


\section{CONTENTS}
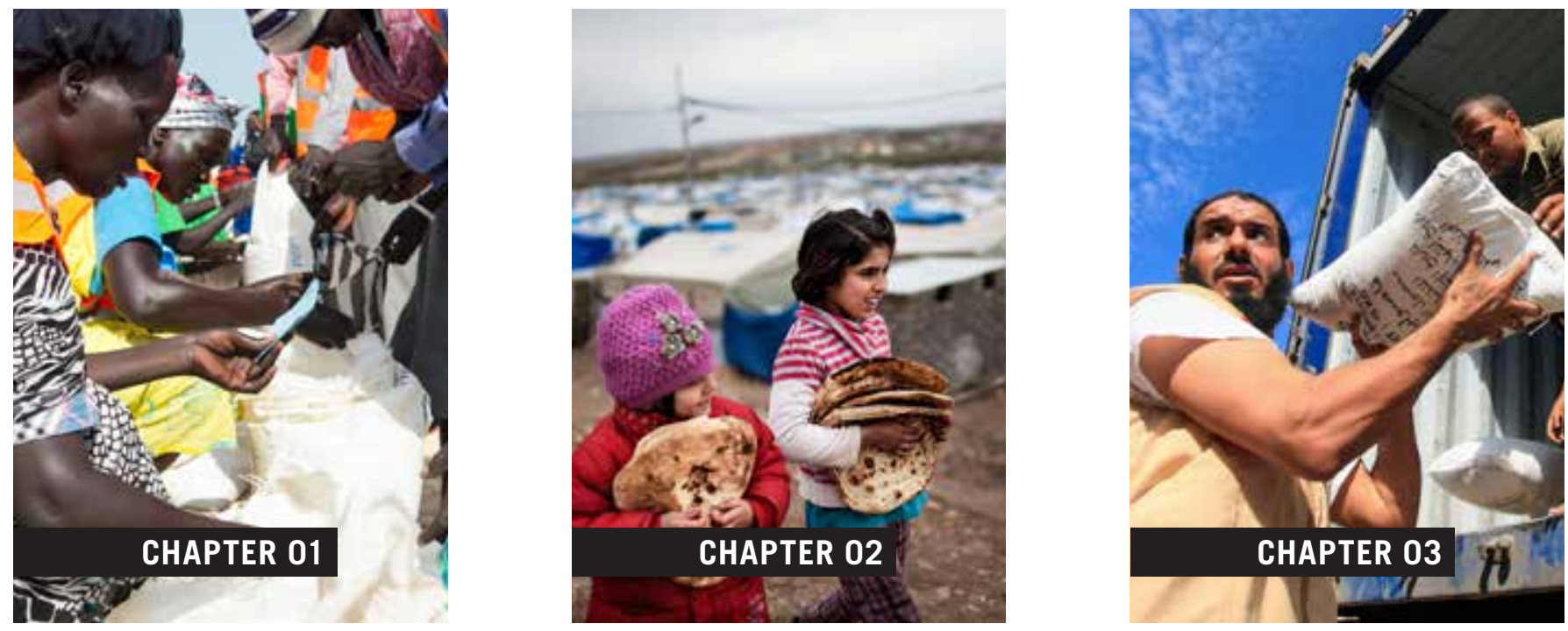

SUMMARY

\section{CHAPTERS}

01 The Concept of the Global Hunger Index 6

02 Global, Regional, and National Trends _ 12

$\mathbf{0 3}$ Armed Conflict and the Challenge of Hunger: Is an End in Sight? 22

\section{APPENDIXES}

A Data Sources for the Global Hunger Index Components, 1990, 1995, 2000, 2005, and 2015

B Data Underlying the Calculation of the 1990, 1995, 2000, 2005, and 2015 Global Hunger Index Scores _........................... 31

C 2015 Global Hunger Index Scores 33

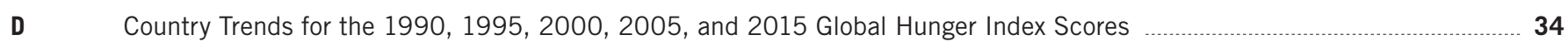

BIBLIOGRAPHY

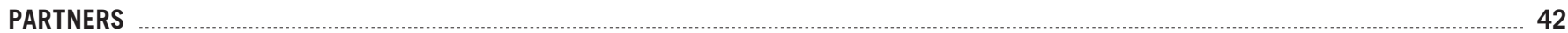


The developing world has made progress in reducing hunger since 2000. The 2015 Global Hunger Index (GHI) shows that the level of hunger in developing countries as a group has fallen by 27 percent. Yet the state of hunger in the world remains serious.

This marks the tenth year that IFPRI has assessed global hunger using this multidimensional measure. This report's GHI scores are based on a new, improved formula that replaces the child underweight indicator of previous years with child stunting and child wasting. This change reflects the latest thinking on the most suitable indicators for child undernutrition, one of three dimensions of hunger reflected in the GHI formula.

Across regions and countries, GHI scores vary considerably. Regionally, the highest GHI scores, and therefore the highest hunger levels, are still found in Africa south of the Sahara and South Asia. Despite achieving the largest absolute improvements since 2000, these two regions still suffer from serious levels of hunger.

Levels of hunger are alarming or serious in 52 countries. Most of the eight countries with alarming GHI scores are in Africa south of the Sahara. While no countries are classified in the extremely alarming category this year, this high level of hunger could still exist. Due to insufficient data, 2015 GHI scores could not be calculated for places that recently suffered from high levels of hunger, including Burundi, Comoros, Democratic Republic of the Congo, Eritrea, Somalia, South Sudan, and Sudan.

From the $2000 \mathrm{GHI}$ to the $2015 \mathrm{GHI}, 17$ countries reduced their scores by 50 percent or more. The 10 countries that achieved the biggest percentage reductions are Azerbaijan, Bosnia and Herzegovina, Brazil, Croatia, Kyrgyz Republic, Latvia, Mongolia, Peru, Ukraine, and Venezuela.

In terms of absolute progress, a comparison of $2000 \mathrm{GHI}$ and 2015 GHI scores reveals that Rwanda, Angola, and Ethiopia saw the biggest improvements in scores. However, despite considerable declines in $\mathrm{GHI}$ scores, their hunger levels remain high.

The countries with the highest $2015 \mathrm{GHI}$ scores, and therefore the highest hunger levels, were the Central African Republic, Chad, and Zambia. It is perhaps not surprising that the first two of these three countries have been plagued with high hunger levels, given the violent conflict and instability their people face. Armed conflict and hunger are strongly associated. The countries with the highest $\mathrm{GHI}$ scores tend to be those engaged in or recently emerged from war.

In this year's essay, Alex de Waal, executive director of the World Peace Foundation, reveals a historic, but unheralded achievement. Calamitous famines - those that cause more than 1 million deathshave been eliminated. What's more, until recently, great faminesthose that kill more than 100,000 people-were much more common. Deaths from these famines exceeded 15 million in five separate decades in the 20th century. In the 21st century, the death toll from great famines is near 600,000 , still cause for concern, yet low by historical standards.

The end of many Communist regimes, the adoption of international human rights norms, and the rise of globalization are among key factors that may help us eliminate famine forever.

Despite a decrease in wars over recent decades, the number of violent conflicts and conflict-related deaths has increased from an all-time low in 2006. While the numbers are still low by historic standards, they suggest much more must be done to eliminate war and hunger.

Today's famines are complex humanitarian emergencies caused mostly by armed conflict. These "new wars" involve not only state armies and insurgents, but also paramilitaries and ethnic militia, criminal gangs, mercenaries, and international forces. Most new wars are civil wars, which increasingly spill over borders and disrupt livelihoods and food systems, forcing people to flee.

Although armed conflict and acute hunger have often travelled hand in hand, history has shown that hunger can be averted. Hunger need not result from conflict.

While the end of calamitous famines is a tremendous achievement, our work is not done. Much more must happen before acute and chronic hunger can be conquered. Economic development, better food policy, conflict resolution, and international humanitarian response must all continue to play important roles in moving us to the next level. Unless the prevalence and persistence of armed conflict can be reduced, and preferably ended, and the needs and rights of both visible and invisible victims of violent conflict can be addressed, the gains will be lost. 


\section{THE CONCEPT OF THE GLOBAL HUNGER INDEX}

The Global Hunger Index (GHI) is a tool designed to comprehensively measure and track hunger globally, regionally, and by country. ${ }^{1}$ Each year, the International Food Policy Research Institute (IFPRI) calculates $\mathrm{GHI}$ scores in order to assess progress, or the lack thereof, in decreasing hunger. The $\mathrm{GHI}$ is designed to raise awareness and understanding of regional and country differences in the struggle against hunger. By calling attention to the issue, we hope that this report will trigger action to reduce hunger around the world.

Hunger is a multidimensional problem, and a variety of terms are used to describe its different aspects (Box 1.1). To reflect the

\section{BOX 1.1 CONCEPTS OF HUNGER}

Hunger is usually understood to refer to the distress associated with lack of food. The Food and Agriculture Organization of the United Nations (FAO) defines food deprivation, or undernourishment, as the consumption of fewer than about 1,800 kilocalories a day-the minimum that most people require to live a healthy and productive life. ${ }^{1}$

Undernutrition goes beyond calories and signifies deficiencies in any or all of the following: energy, protein, or essential vitamins and minerals. Undernutrition is the result of inadequate intake of food in terms of either quantity or quality, poor utilization of nutrients due to infections or other illnesses, or a combination of these factors. These, in turn, are caused by a range of factors including household food insecurity; inadequate maternal health or childcare practices; or inadequate access to health services, safe water, and sanitation.

Malnutrition refers more broadly to both undernutrition (problems of deficiencies) and overnutrition (problems of unbalanced diets, which includes consuming too many calories in relation to energy requirements, with or without low intake of micronutrient-rich foods).

In this report, "hunger" refers to the index based on the four component indicators. Taken together, the component indicators reflect deficiencies in calories as well as in micronutrients. Thus, the $\mathrm{GHI}$ reflects both aspects of hunger.

FAO considers the composition of a population by age and sex to calculate its average minimum energy requirement for an individual engaged in low physica activity. This requirement varies by country - from about 1,650 to more than 1,900 kilocalories per person per day for developing countries in 2014-2016 (FAO 2015). Each country's average minimum energy requirement for low physical activity is used to estimate undernourishment (FAO, IFAD, and WFP 2015). multidimensional nature of hunger, the GHI combines the following four component indicators into one index:

1. UNDERNOURISHMENT: the proportion of undernourished people as a percentage of the population (reflecting the share of the population with insufficient caloric intake);

2. CHILD WASTING: the proportion of children under the age of five who suffer from wasting (that is, low weight for their height, reflecting acute undernutrition);

3. CHILD STUNTING: the proportion of children under the age of five who suffer from stunting (that is, low height for their age, reflecting chronic undernutrition); and

4. CHILD MORTALITY: the mortality rate of children under the age of five (partially reflecting the fatal synergy of inadequate nutrition and unhealthy environments). ${ }^{2}$

There are several advantages to measuring hunger using this multidimensional approach (Figure 1.1). It reflects the nutrition situation of not only the population as a whole, but also of children-a vulnerable subset of the population for whom a lack of dietary energy, protein, or micronutrients (essential vitamins and minerals) leads to a high risk of illness, poor physical and cognitive development, or death. It also combines independently measured indicators to reduce the effects of random measurement errors. ${ }^{3}$

This year, GHI scores have been calculated using a revised and improved formula (Box 1.2). The revision replaces child underweight, previously the sole indicator of child undernutrition, with two indicators of child undernutrition — child wasting and child stunting - which are equally weighted in the GHI calculation. The revised formula also standardizes each of the component indicators to balance their contribution to the overall index and to changes in GHI scores over time (Box 1.3).

The $2015 \mathrm{GHI}$ has been calculated for 117 countries for which data on the four component indicators are available and where measuring hunger is considered most relevant. GHI scores are not calculated for some higher-income countries where the prevalence of hunger is very low. The GHI is only as current as the data for its four

\footnotetext{
For background information on the GHI concept, see Wiesmann (2004) and Wiesmann, von Braun, and Feldbrügge (2000)

2 According to recent estimates, undernutrition is responsible for 45 percent of deaths among children younger than five years old (Black et al. 2013).

${ }^{3}$ For a multidimensional measure of poverty, see the index developed by the Oxford Poverty and Human Development Initiative for the United Nations Development Programme (Alkire and Santos 2010).
} 


\begin{tabular}{|c|c|c|c|}
\hline Three dimensions & Four indicators & Weight & Reasons for inclusion \\
\hline $\begin{array}{l}\text { Inadequate food supply } \\
\text { FAO }\end{array}$ & Undernourishment & $1 / 3$ & $\begin{array}{l}\rightarrow \text { Measures insufficient food supply, } \\
\text { an important indicator of hunger } \\
\rightarrow \text { Refers to the entire population, both } \\
\text { children and adults } \\
\rightarrow \text { Used as a lead indicator for } \\
\text { international hunger targets }\end{array}$ \\
\hline $\begin{array}{l}\text { Child undernutrition } \\
\text { UNICEF } \\
\text { WHO } \\
\text { WORLD BANK }\end{array}$ & Wasting & $1 / 6$ & $\begin{array}{l}\rightarrow \text { Goes beyond calorie availability, } \\
\text { considers aspects of diet quality and } \\
\text { utilization } \\
\rightarrow \text { Children are particularly vulnerable to } \\
\text { nutritional deficiencies }\end{array}$ \\
\hline & Stunting & $1 / 6$ & $\begin{aligned} & \rightarrow \text { Is sensitive to uneven distribution of } \\
& \text { food within the household } \\
& \rightarrow \text { Stunting and wasting are the suggested } \\
& \text { nutrition indicators for the Sustainable } \\
& \text { Development Goals (SDGs) }\end{aligned}$ \\
\hline $\begin{array}{l}\text { Child mortality } \\
\text { IGME }\end{array}$ & $\begin{array}{l}\text { Under-five } \\
\text { mortality rate }\end{array}$ & $1 / 3$ & $\begin{array}{l}\rightarrow \text { Death is the most serious } \\
\text { consequence of hunger, and children } \\
\text { are most vulnerable } \\
\rightarrow \text { Improves the GHI's ability to reflect } \\
\text { micronutrient deficiencies } \\
\rightarrow \text { Wasting and stunting only partially } \\
\text { capture the mortality risk of } \\
\text { undernutrition }\end{array}$ \\
\hline
\end{tabular}

Source: Wiesmann et al. (2015).

Notes: Each indicator is standardized. The child undernutrition indicators include data from additional sources where available. See pp. 10-11 for a list of all child undernutrition data sources used in this report.

component indicators. This year's GHI reflects the most recent country-level data and projections available between 2010 and 2016. It therefore reflects hunger levels during this period rather than solely capturing the conditions in $2015 .{ }^{4}$ For some countries, such as Burundi, Comoros, the Democratic Republic of the Congo, Eritrea, Papua New Guinea, South Sudan, Sudan, and Syria, lack of data on undernourishment prevents the calculation of GHI scores. ${ }^{5}$

The scores are based on source data that are continuously revised by the United Nations (UN) agencies that compile them, and each year's GHI report reflects these revisions. While these revisions result in improvements in the data, they also mean that the GHI scores from different years' reports are not comparable with one another. Also, with the use of the revised formula in this year's report, direct comparisons between this report's findings and the scores from previous GHI reports are not possible. This year's report contains GHI scores for 2015 and four reference periods-1990, 1995, 2000, and 2005. All scores were calculated using the revised formula. This allows for valid comparisons of hunger levels over time.

The 1990, 1995, 2000, 2005, and $2015 \mathrm{GHI}$ scores presented in this year's report reflect the latest revised data for the four component

\footnotetext{
4 The latest undernourishment estimates from the Food and Agriculture Organization of the United Nations (FAO) include projections for 2014-2016, which are used in the calculation of the $2015 \mathrm{GHI}$ (FAO, IFAD, and WFP 2015).

5 FAO stopped publishing country-level estimates of undernourishment for the Democratic Republic of the Congo in 2011 (FAO, IFAD, and WFP 2011). According to past GHI reports, the GHI score of the Democratic Republic of the Congo was in the extremely alarming category with the highest levels of hunger. For South Sudan, which became independent in 2011, and present-day Sudan, separate undernourishment estimates are not yet available from FAO (FAO, IFAD, and WFP 2015).
} 


\section{BOX 1.2 HOW GHI SCORES ARE CALCULATED}

GHI scores are calculated using a three-step process.

First, values for each of the four component indicators are determined from the available data for each country. The four indicators are

$\rightarrow$ the percentage of the population that is undernourished,

$\rightarrow$ the percentage of children under five years old who suffer from wasting (low weight for height),

$\rightarrow$ the percentage of children under five years old who suffer from stunting (low height for age), and

$\rightarrow$ the percentage of children who die before the age of five (child mortality).

Second, each of the four component indicators is given a standardized score based on thresholds set slightly above the highest country-level values observed worldwide for that indicator between 1988 and 2013. ${ }^{1}$ For example, the highest value for undernourishment estimated in this period is 76.5 percent, so the threshold for standardization was set a bit higher, at 80 percent. $^{2}$ In a given year, if a country has an undernourishment prevalence of 40 percent, its standardized undernourishment score for that year is 50 . In other words, that country is approximately halfway between having no undernourishment and reaching the maximum observed levels.

Third, the standardized scores are aggregated to calculate the GHI score for each country. Undernourishment and child mortality each contribute one-third of the GHI score, while the child undernutrition indicators-child wasting and child stunting-each contribute one-sixth of the score.

This calculation results in GHI scores on a 100-point scale where 0 is the best score (no hunger) and 100 the worst. In practice, neither of these extremes is reached. A value of 100 would signify that a country's undernourishment, child wasting, child stunting, and child mortality levels each exactly meet the thresholds set slightly above the highest levels observed worldwide in recent decades. A value of zero would mean that a country had no undernourished people in the population, no children younger than five who were wasted or stunted, and no children who died before their fifth birthday.

The scale below shows the severity of hunger-from low to extremely alarming-associated with the range of possible GHI scores using the revised formula.

\section{STEP 1 Determine values for the component indicators:}

PUN proportion of the population that is undernourished (in \%)

CWA prevalence of wasting in children under five years old (in \%)

CST prevalence of stunting in children under five years old (in \%)

$\mathrm{CM}$ proportion of children dying before the age of five (in \%)

\section{STEP 2 Standardize component indicators:}

$$
\begin{aligned}
& \text { Standardized PUN }=\frac{\mathrm{PUN}}{80} \times 100 \\
& \text { Standardized CWA }=\frac{\mathrm{CWA}}{30} \times 100 \\
& \text { Standardized CST }=\frac{\mathrm{CST}}{70} \times 100 \\
& \text { Standardized CM }=\frac{\mathrm{CM}}{35} \times 100
\end{aligned}
$$

\section{STEP 3 Aggregate component indicators:}

$$
\frac{1}{3} \times \text { Standardized PUN }
$$

\begin{tabular}{|c|c|c|c|c|}
\hline \multicolumn{5}{|c|}{ GHI Severity Scale } \\
\hline $\begin{array}{l}\leq 9.9 \\
\text { low }\end{array}$ & $\begin{array}{l}10.0-19.9 \\
\text { moderate }\end{array}$ & $\begin{array}{c}20.0-34.9 \\
\text { serious }\end{array}$ & $\begin{array}{c}35.0-49.9 \\
\text { alarming }\end{array}$ & $\begin{array}{l}50.0 \leq \\
\text { extremely alarming }\end{array}$ \\
\hline
\end{tabular}

$+\frac{1}{6} \times$ Standardized CWA

$+\frac{1}{6} \times$ Standardized CST

$+\frac{1}{3} \times$ Standardized CM

$=\mathrm{GHI}$ Score

1 The thresholds for standardization are set slightly above the highest observed values in order to allow for the possibility that these values could be exceeded in the future.

2 The threshold for undernourishment is 80 , based on the observed maximum of 76.5 percent; the threshold for child wasting is 30 , based on the observed maximum of 26.0 percent; the threshold for child stunting is 70 , based on the observed maximum of 68.2 percent; and the threshold for child mortality is 35 , based on the observed maximum of 32.6 percent. 


\section{BOX 1.3 WHY THE GLOBAL HUNGER INDEX WAS REVISED}

The Global Hunger Index (GHI) was first released by the International Food Policy Research Institute and Welthungerhilfe in 2006. ${ }^{1}$ Since then it has been published with updated data each year. Previously, the Index included the following three, equally weighted, nonstandardized indicators:

1. the proportion of the population that is undernourished;

2. the prevalence of underweight in children under five; and

3. the under-five mortality rate.

This year, in order to reflect the current thinking in nutrition measurement and common practice in index construction, the formula was revised to replace child underweight with child wasting and child stunting, and to standardize each of the component indicators (Wiesmann et al. 2015). Each of these changes is described here.

The prevalence of underweight in children under five was previously the preferred indicator of undernutrition in children. Yet, underweight has been questioned in recent years in terms of its effectiveness in monitoring child undernutrition. In part, this is because a child may be of normal weight, or even overweight, for his or her age, and yet be stunted (Martorell 2008). In this scenario, simply measuring underweight would give the false impression that this child is well-nourished, while failing to take into account evidence of stunting, an indicator of chronic undernutrition. To remedy this issue and to bring more nuance to the GHI, child underweight has been replaced with child wasting and child stunting. The other component indicators-undernourishment and child mortality-remain unchanged.

In previous editions of the index, the component indicators of the GHI were not standardized. However, the values for undernourishment and child stunting are typically higher than the values for child mortality and child wasting, and vary more greatly across countries. To understand why this is important, imagine that a country historically has had a child mortality rate of 10 percent and an undernourishment prevalence of 50 percent. If child mortality is reduced to 5 percent and the prevalence of undernourishment is reduced to 45 percent, this is an absolute change of 5 percentage points for each indicator. In the previous $\mathrm{GHI}$ formula, both changes would have had the same effect on the GHI score. However, because the undernourishment indicator has generally higher levels and tends to fluctuate more than the child mortality indicator, a reduction of 5 percentage points in the child mortality rate actually represents a more meaningful decline. By using standardized values in the new formula, a decline of 5 percentage points in the child mortality rate has a greater effect on the overall GHI score than a change of the same amount in the prevalence of undernourishment. Thus, by standardizing the values of the four component indicators, their effects on GHI scores can be balanced in any given year and over time.

${ }^{1}$ Concern Worldwide joined the partnership in 2007 indicators of the GHI. ${ }^{6}$ Where original source data were not available, the estimates for the GHI component indicators were based on the most recent data available. (See Appendix A for more detailed background information on the data sources for the 1990, 1995, 2000, 2005, and 2015 GHI scores.)

The four component indicators used to calculate the $\mathrm{GHI}$ scores in this report draw upon data from the following sources:

UNDERNOURISHMENT: Updated data from the Food and Agriculture Organization of the United Nations (FAO) were used for the 1990, 1995, 2000, 2005, and 2015 GHI scores. Undernourishment data and projections for the $2015 \mathrm{GHI}$ are for 2014-2016 (FAO 2015; authors' estimates).
CHILD WASTING AND CHILD STUNTING: The child undernutrition indicators of the $\mathrm{GHI}$ - child wasting and child stunting —include data from the joint database of UNICEF, the World Health Organization (WHO), and the World Bank, and additional data from WHO's continuously updated Global Database on Child Growth and Malnutrition; the most recent Demographic and Health Survey (DHS) and Multiple Indicator Cluster Survey (MICS) reports; statistical tables from UNICEF; and the latest national survey data for India from UNICEF India. ${ }^{7}$ For the $2015 \mathrm{GHI}$, data on child wasting and child stunting are for the latest year for which data are available in the period

6 For previous GHI calculations, see von Grebmer et al. (2014, 2013, 2012, 2011, 2010 , 2009, 2008); IFPRI/Welthungerhilfe/Concern (2007); Wiesmann (2006a, b); and Wiesmann, Weingärtner, and Schöninger (2006).

7 Data on India's latest child stunting and wasting rates are provisional. 
2010-2014 (UNICEF/WHO/World Bank 2015; WHO 2015; UNICEF 2015a; UNICEF 2013; UNICEF 2009a; MEASURE DHS 2015; India, Ministry of Women and Child Development, and UNICEF 2014; authors' estimates).

CHILD MORTALITY: Updated data from the UN Inter-agency Group for Child Mortality Estimation were used for the 1990, 1995, 2000, 2005 , and $2015 \mathrm{GHI}$ scores. For the $2015 \mathrm{GHI}$, data on child mortality are for 2013 (IGME 2014).
Despite the existence of advanced technology to collect and assess data almost instantaneously, time lags and data gaps persist in reporting vital statistics on hunger and undernutrition. While recent improvements have been made and projections of undernourishment are now available up to 2016, more reliable and extensive country data are still urgently needed. Further improvements in collecting high-quality data on hunger and undernutrition will allow for a more complete and current assessment of the state of global hunger, which can, in turn, better guide efforts to end hunger. 


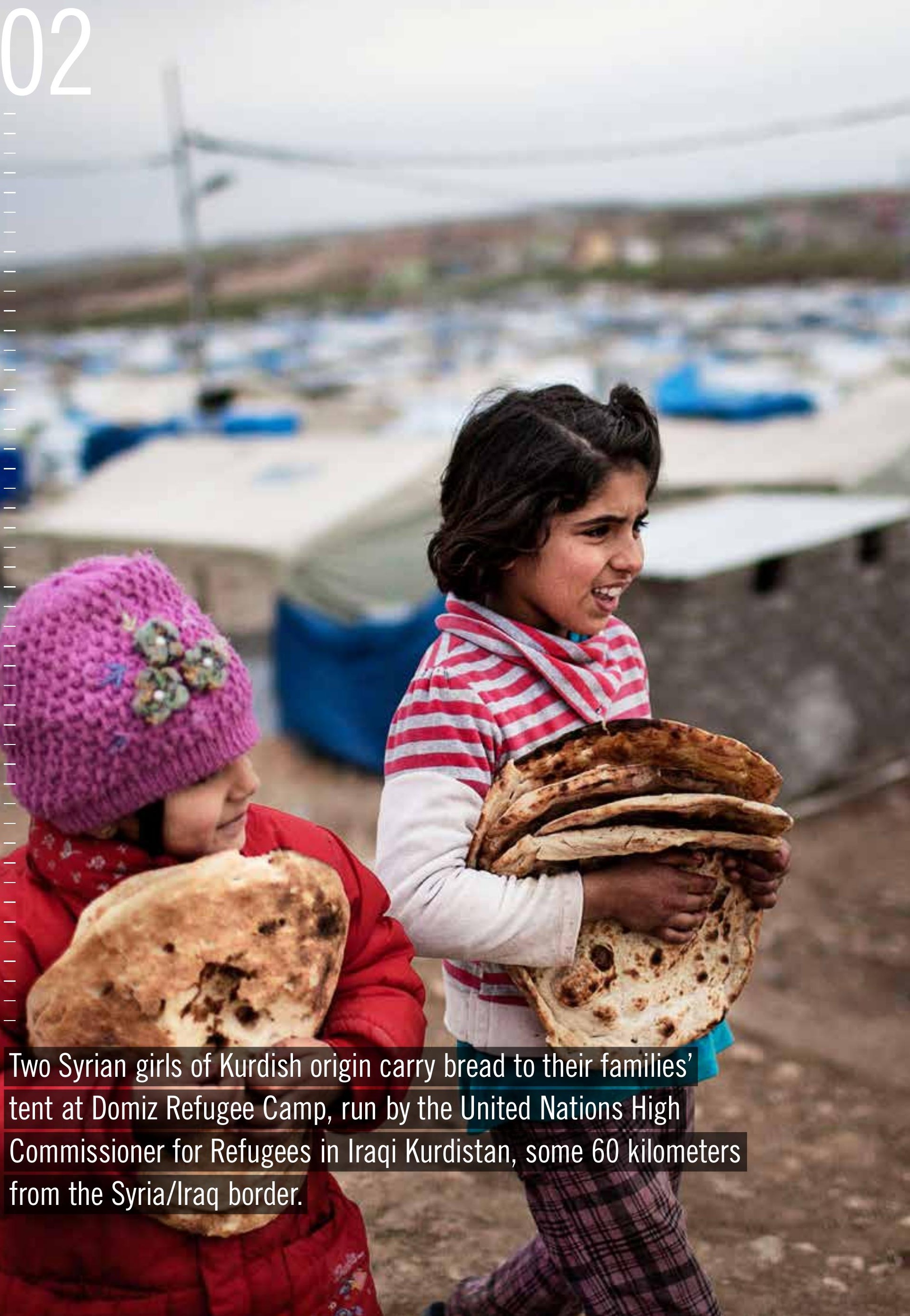




\section{GLOBAL, REGIONAL, AND NATIONAL TRENDS}

Since 2000, significant progress has been made in the fight against hunger. ${ }^{1}$ The 2000 Global Hunger Index (GHI) score was 29.9 for the developing world, while the $2015 \mathrm{GHI}$ score stands at 21.7, representing a reduction of 27 percent (Figure 2.1). ${ }^{2}$ To put this in context, the higher the GHI score, the higher the level of hunger. Scores between 20.0 and 34.9 points are considered serious. Thus while the GHI scores for the developing world —also referred to as the global GHI scores-for 2000 and 2015 are both in the serious category, the earlier score was closer to being categorized as alarming, while the later score is closer to the moderate category. As described in Chapter 1, all GHI calculations in this report, including those for the reference years 1990, 1995, 2000, and 2005, have been calculated using a revised formula. The severity scale was adjusted to reflect this change.

Despite the lower hunger level reflected by the 2015 global GHI score, the number of hungry people in the world remains unacceptably high. According to projections from the Food and Agriculture Organization of the United Nations (FAO), about 795 million people worldwide-roughly one in nine-are estimated to be chronically undernourished in 2014-2016 (FAO, IFAD, and WFP 2015). As of 2013, 161 million children-approximately one in four-were stunted, and 51 million children suffered from wasting (UNICEF 2015b). Nearly half of all child deaths under age five are due to malnutrition, which claims the lives of about 3.1 million children per year (Black et al. 2013). Although substantial progress has been made, one need only look to the countries that still have serious or alarming hunger levels, the regions in any country that experience disproportionate hunger, or the children who will suffer lifelong consequences as a result of malnutrition early in life, to see that much work remains to be done.

In the developing world, the four $\mathrm{GHI}$ components (undernourishment, child stunting, child wasting, and child mortality) have each declined since 2000, although at different rates. The proportion of the population that is undernourished dropped 29 percent, from 18.5 percent to 13.1 percent. The prevalence of child stunting declined by 25 percent since 2000 , going from 37.5 percent to 28.2 percent. The proportion of children who suffer wasting fell by 10 percent, going from 9.8 percent to 8.8 percent. Finally,

${ }^{1}$ While the analysis in previous GHI reports focused on comparisons with hunger levels in 1990, the analysis in this year's report centers on comparisons with hunger levels in 2000. Many countries experienced fluctuations between 1990 and 2015, and making comparisons with 2000 captures more recent trends.

2 The regional and global aggregates for each component indicator are calculated as population-weighted averages, using the indicator values reported in Appendix B. Provisional estimates for undernourishment for Burundi, Comoros, the Democratic Republic of the Congo, Eritrea, Libya, Papua New Guinea, Somalia, and Syria were used in the calculation of the global and regional aggregates only, but are not reported in Appendix B. These estimates are based on previously published undernourishment data and provisional estimates provided by FAO in 2014 for the sake of regional and global aggregation only. The regional and global $\mathrm{GHI}$ scores are calculated using the regional and global aggregates for each indicator and the revised formula described in Chapter 1 .

\section{FIGURE 2.1 DEVELOPING WORLD AND REGIONAL 1990, 1995, 2000, 2005, AND 2015 GLOBAL HUNGER INDEX SCORES,}

WITH CONTRIBUTION OF COMPONENTS

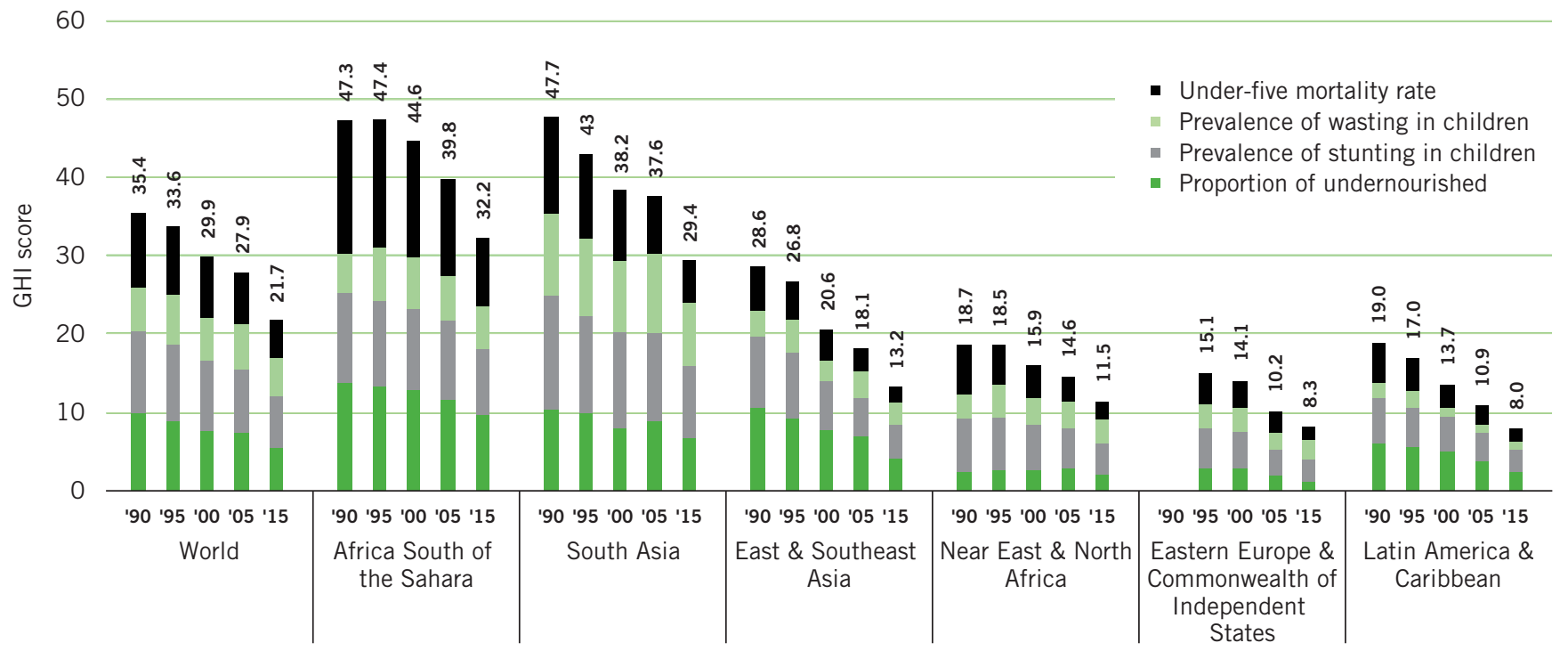

Note: See Appendix A for data sources. A 1990 regional score for Eastern Europe and the Commonwealth of Independent States was not calculated, because many countries were not in their present borders. 
the proportion of children dying before the age of five dropped by 40 percent, going from 8.2 percent to 4.9 percent. $^{3}$

\section{Large Regional Differences}

The global averages mask dramatic differences among regions and countries. Africa south of the Sahara and South Asia have the highest 2015 GHI scores, at 32.2 and 29.4 respectively. Both reflect serious levels of hunger. In contrast, the GHI scores for East and Southeast Asia, Near East and North Africa, Latin America and the Caribbean, and Eastern Europe and the Commonwealth of Independent States range between 8.0 and 13.2, and represent low or moderate levels of hunger.

In terms of absolute change, Africa south of the Sahara and South Asia have experienced the greatest improvements from the $2000 \mathrm{GHI}$ to the $2015 \mathrm{GHI}$, with reductions of 12.4 and 8.8 points, respectively. East and Southeast Asia also reduced its GHI score by a sizeable amount, 7.4 points since the $2000 \mathrm{GHI}$. The Near East and North Africa, Latin America and the Caribbean, and Eastern Europe and the Commonwealth of Independent States reduced their $\mathrm{GHI}$ scores by 4.4 to 5.8 points, despite already having the lowest $2000 \mathrm{GHI}$ scores.

In terms of the percentage change since the $2000 \mathrm{GHI}$, two regions-Eastern Europe and the Commonwealth of Independent States and Latin America and the Caribbean-experienced declines of just over 40 percent. East and Southeast Asia was not far behind, with a reduction of 36 percent. Africa south of the Sahara and the Near East and North Africa each reduced their GHI scores by 28 percent. Since 2000, South Asia's GHI score dropped 23 percent. Given that the hunger level for Africa south of the Sahara stagnated between 1990 and 1995, it is notable that its GHI score has declined at a rate comparable to other regions' rates since 2000 .

South Asia's GHI score declined at a moderate rate between 1990 and 2000, but then progress stalled between 2000 and 2005 before hunger levels dropped again between 2005 and 2015 . This closely follows the trend of GHI scores for India, where nearly three-quarters of South Asia's population lives. The decrease of more than 8 points in South Asia's GHI score since 2005 may be largely attributed to recent successes in the fight against child undernutrition in India. According to the most recent data from India, wasting in children fell from 20 percent to 15 percent between 2005-2006 and 2013-2014, and stunting fell from 48 percent to 39 percent in the same period (IIPS and Macro International 2007; India, Ministry of Women and Child Development, and UNICEF 2014). ${ }^{4}$

The government of India has scaled up nutrition-specific interventions over the past decade, including (1) a final drive to expand the Integrated Child Development Services program that aims to improve the health, nutrition, and development of children in India; and (2) the creation of the National Rural Health Mission, a community-based health initiative designed to deliver essential health services to rural India (Avula et al. 2013). However, progress in reducing child undernutrition has been uneven across India's states. While the reasons for the improvements-or lack thereof-are not entirely clear, one factor that seems to correlate with undernutrition in India is open defecation, which contributes to illnesses that prevent the absorption of nutrients. Additionally, the low social status of women, which affects women's health and nutrition, makes it more likely that babies will be born underweight (Economist 2015).

Africa south of the Sahara has the highest $2015 \mathrm{GHI}$ score, at 32.2. Overall, since 2000, the region has experienced strong economic growth (UNCTAD 2014). It has also benefitted from advances in public health, including lower transmission levels and better treatment of HIV/AIDS, and fewer cases and deaths from malaria (AVERT 2014; WHO 2013). In some countries, such as Angola, Ethiopia, and Rwanda, the large-scale civil wars of the 1990s and 2000s have ended. These countries have become more politically stable and hunger levels have fallen substantially. On the other hand, countries such as the Central African Republic and Chad have experienced conflict more recently and also have experienced higher levels of hunger, although the causes of hunger are complex and cannot be attributed to conflict alone. Despite improvements, the high levels of hunger in Africa south of the Sahara, both regionally and in individual countries, are still cause for concern.

An issue of vital importance to Africa south of the Sahara is the link between agriculture and nutrition. More than two-thirds of the region's population relies on agriculture for income, including more than 90 percent of the region's extreme poor (O'Sullivan et al. 2014). Yet the area's agricultural productivity levels are the lowest of any region in the world. The solutions for Africa will undoubtedly be complex, in part because ecological conditions and social circumstances vary throughout the continent. As part of the fight against hunger, organizations at all levels must continue to find ways to improve agricultural productivity, along with dietary diversity and environmental sustainability, in order to benefit the most vulnerable.

\footnotetext{
${ }^{3}$ The estimates in this paragraph refer to the countries of the developing world for which GHI data were available. These estimates can vary slightly from estimates published by other organizations for the same indicators due to the inclusion of different countries.

4 Data on India's child stunting and wasting rates in 2013-2014 were provisional and were obtained in 2014 through personal communication with India's Ministry of Women and Child Development.
} 
Percentage change in 2015 GHI compared with 2000 GHI

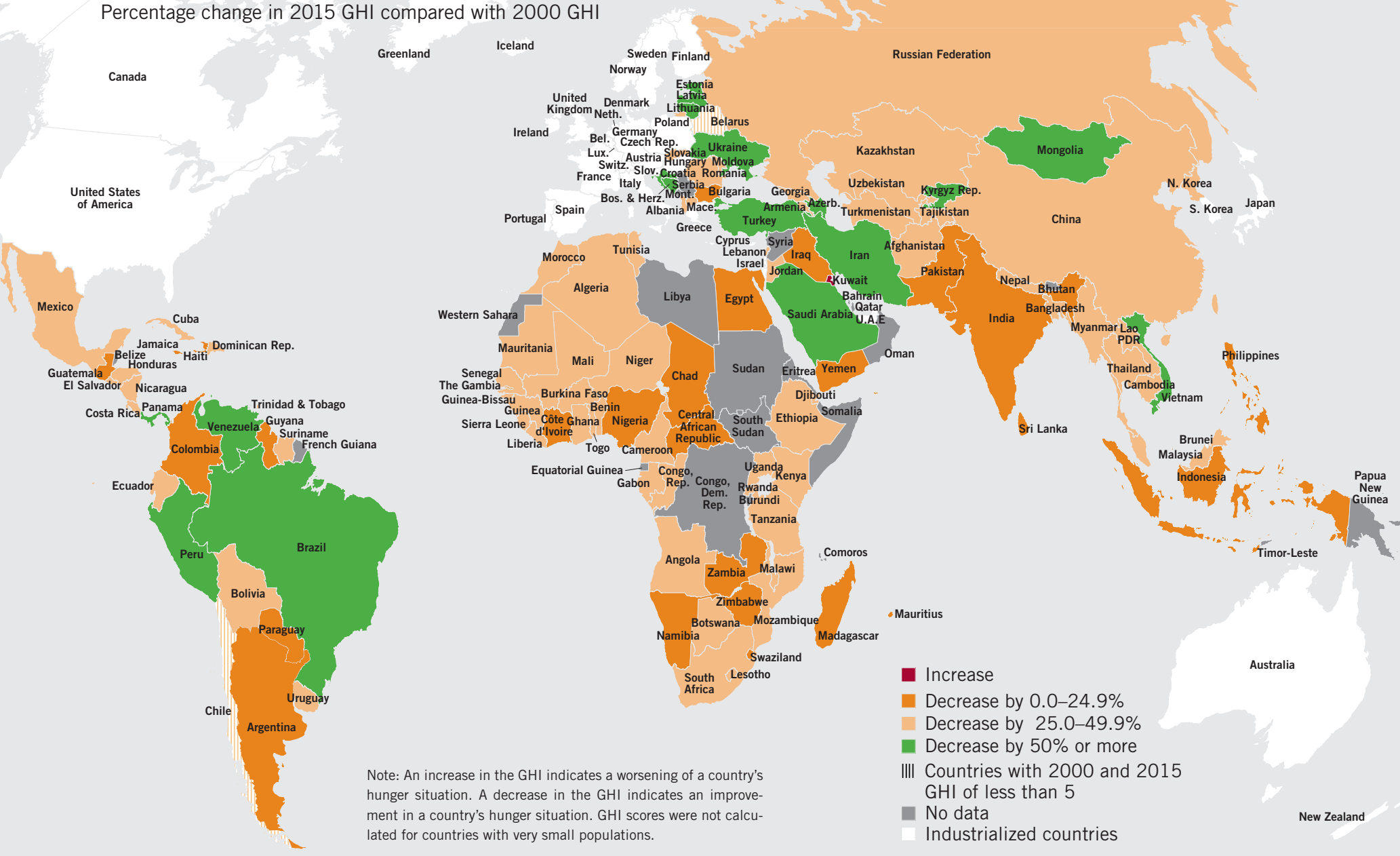

\section{Best and Worst Country-Level Results}

From the $2000 \mathrm{GHI}$ to the $2015 \mathrm{GHI}, 17$ countries made remarkable progress, reducing their $\mathrm{GHI}$ scores by 50 percent or more (Figure 2.2). Sixty-eight countries made considerable progress with scores that dropped by between 25.0 percent and 49.9 percent, and 28 countries decreased their GHI scores by less than 25 percent. Despite this progress, 52 countries still suffer from serious or alarming levels of hunger.

Of the countries that achieved the 10 biggest percentage reductions in GHI scores from the $2000 \mathrm{GHI}$ to the $2015 \mathrm{GHI}$, three are in South America (Brazil, Peru, and Venezuela), one is in Asia (Mongolia), four are former Soviet republics (Azerbaijan, Kyrgyz Republic, Latvia, and Ukraine), and two are former Yugoslav republics (Bosnia and Herzegovina plus Croatia). The GHI scores for each of these countries have declined significantly — between 53 and 71 percent since the $2000 \mathrm{GHI}$.

Brazil reduced its $2000 \mathrm{GHI}$ score by roughly two-thirds. Its impressive progress was partially due to the government's Zero Hunger program, which included Bolsa Família-a large-scale conditional cash transfer program. Bolsa Família contributed to decreased child mortality in Brazil, in part via improved nutrition, by requiring families to participate in health-related activities, including nutrition education, for pregnant and lactating women (Rasella et al. 2013). The Zero Hunger program also included programs to support family farms and increase the availability of fruits and vegetables (Rocha 2009). In 2009, Brazil met its Millennium Development Goal of reducing poverty and malnutrition by half-several years before the 2015 deadline. Yet, poor diet quality, overweight, and obesity remain challenges.

Peru made impressive progress by cutting its $2000 \mathrm{GHI}$ score by 56 percent. Besides being one of Latin America's fastest growing economies (World Bank 2015b), the country has gained recognition in recent years for its dedication to fighting hunger and undernutrition (Gillespie et al. 2013). During the 2006 and 2011 Peruvian presidential campaigns, the Initiative against Child Malnutrition (IDI), a broad alliance led by civil society organizations, put fighting chronic undernutrition on the campaign agenda, making all candidates pledge, if elected, to reduce child stunting by at least five percentage points in five years.

Consequently, President Alan García established a multisectoral agenda that helped reduce child stunting by nearly 10 percentage points to 18 percent between 2006 and 2011 (Acosta and Haddad 2014). After taking office in 2011 with a vow to eradicate poverty, President Ollanta Humala implemented the national Include to Grow strategy and established the Ministry of Development and Social Inclusion to facilitate intersectoral coordination on issues including undernutrition. Despite recent progress, inequality is an ongoing 
challenge. In the last decade, in a sample of 53 countries in the developing world, Peru stood out as the country where child undernutrition levels were the most highly correlated with family socioeconomic status (Bredenkamp, Buisman, and Van de Poel 2014).

Mongolia also saw a 56 percent drop between its 2000 and 2015 GHI scores. In the period between 2000 and 2015, Mongolia experienced steady economic growth, with the exception of a brief downturn during the 2008 global financial crisis. The combination of economic growth, driven by rising mining and quarrying revenues, and social welfare programs, including a comprehensive national nutrition strategy to tackle undernutrition (UNICEF 2009b), coincided with decreased poverty and hunger levels in the period between 2000 and 2015, as well as reductions in the values of all the $\mathrm{GHI}$ component indicators. Yet poverty and undernutrition have persisted in Mongolia's rural areas, particularly for small-scale livestock herders and their families, who are vulnerable to extreme weather patterns and environmental degradation (Mongolia 2013).

For the former Communist countries, the situation in each country is unique, yet certain trends emerge. For many of the former Soviet and Yugoslav states, the transition out of Communism to capitalism was rocky and characterized by recessions in the 1990s. Yet in the 2000s, economic growth was strong until the 2008 global financial crisis, which hit these countries particularly hard. The former Communist states have mostly recovered from the recession and reestablished modest economic growth, although negative impacts of the 2008 recession persist (Roaf et al. 2014).

For each of these countries, the relationship between macroeconomic growth, poverty, and hunger levels has differed. For example, in recent years, Azerbaijan's economic growth has been driven by oil revenues. Government programs to boost wages, provide social protection, and invest in the public sector helped ensure that the economic benefits were dispersed throughout the population (UNDP 2012). Ukraine, too, has seen a reduction in poverty and hunger as GDP increased since 2000, yet significant inequality has left marginalized groups such as women, children, and the elderly vulnerable to hunger and poverty (Ukraine, Ministry of Economy 2010). Also, unrest in Ukraine between 2013 and early 2015 reportedly contributed to food shortages in the country (Lambers 2015; WFP 2015a). The effect of the unrest on hunger levels in the future remains to be seen.

Since 2000, Rwanda, Angola, and Ethiopia have seen the biggest reductions in hunger, with GHI scores down by between 25 and 28 points in each country. Despite these improvements, the hunger levels in these countries are still serious. In fact, among the countries for which data were available, Rwanda, Angola, and Ethiopia had the three highest GHI scores in 2000 (58.5, 58.3, and 58.6, respectively), which explains why hunger levels are still high $(30.3,32.6$, and 33.9), despite the remarkable reductions. These countries are also recovering from a legacy of civil war, and although it is not possible to directly attribute their hunger levels to the previous conflicts, they undoubtedly contributed to the challenges these countries face.

In Rwanda, poverty and hunger spiked after the country's deadly civil war (1990-1993), which culminated in the Rwandan genocide in 1994. However, in the postwar period, Rwanda's government has intentionally designed policies to promote inclusive economic growth, and the country has experienced increasing Gross Domestic Product (GDP) levels along with decreasing inequality, particularly since 2005-2006 (UNDP 2015). Rwanda's child mortality rate was down to 5.2 percent as of 2013 , and child wasting was 3.0 percent according to a 2010-2011 survey, suggesting that acute malnutrition has waned. However, child stunting was still high, at 44.3 percent.

Angola, too, is recovering from civil war. The country endured a 27-year struggle that ended in 2002 (World Bank 2015a). The country's GDP increased substantially after the war's end, primarily driven by increased oil revenues. The prevalence of undernourishment has decreased from 63.5 percent in 1990-1992 to 14.2 percent in 2014-2016 (FAO 2015). Yet, child mortality was still high, at 16.7 percent in 2013. Some claim that Angola's problem is not a lack of food, but rather its dependence on food with little nutritional value, which in turn leads to child undernutrition and high child mortality (McClelland and Soque 2015).

Ethiopia experienced multiple, simultaneous civil wars between 1974 and 1991, along with severe famines during this period, including the worst famine in current history between 1983 and 1985 (Africa Watch 1991; von Braun and Olofinbiyi 2007). Its hunger situation remains serious, particularly for women and children. The government of Ethiopia has established several programs to address the issue, yet recurring droughts and the population's heavy dependence on rainfed agriculture, which is plagued by low productivity levels, present ongoing challenges for food security (USAID 2014).

Only one country-Kuwait-experienced an increase in its score between 2000 and 2015. However, the increase, from a 4.2 score to a 5.0 score between the $2000 \mathrm{GHI}$ and $2015 \mathrm{GHI}$, is small in absolute terms and Kuwait's hunger level is still categorized as low. Most importantly, Kuwait's 2015 score of 5.0 represents a dramatic improvement compared to 1990 and 1995, when its GHI scores were 24.3 (serious) and 16.1 (moderate) respectively. In fact, according to the 2014 GHI report, which compared 2014 scores with 1990 scores, Kuwait was the biggest "winner," given that it experienced the largest percentage reduction in GHI scores among all the countries for which scores were calculated. The unusually high score in 1990 was due to Iraq's invasion of Kuwait, which precipitated the first Gulf War. The evolution of Kuwait's hunger levels should be evaluated in that context. 


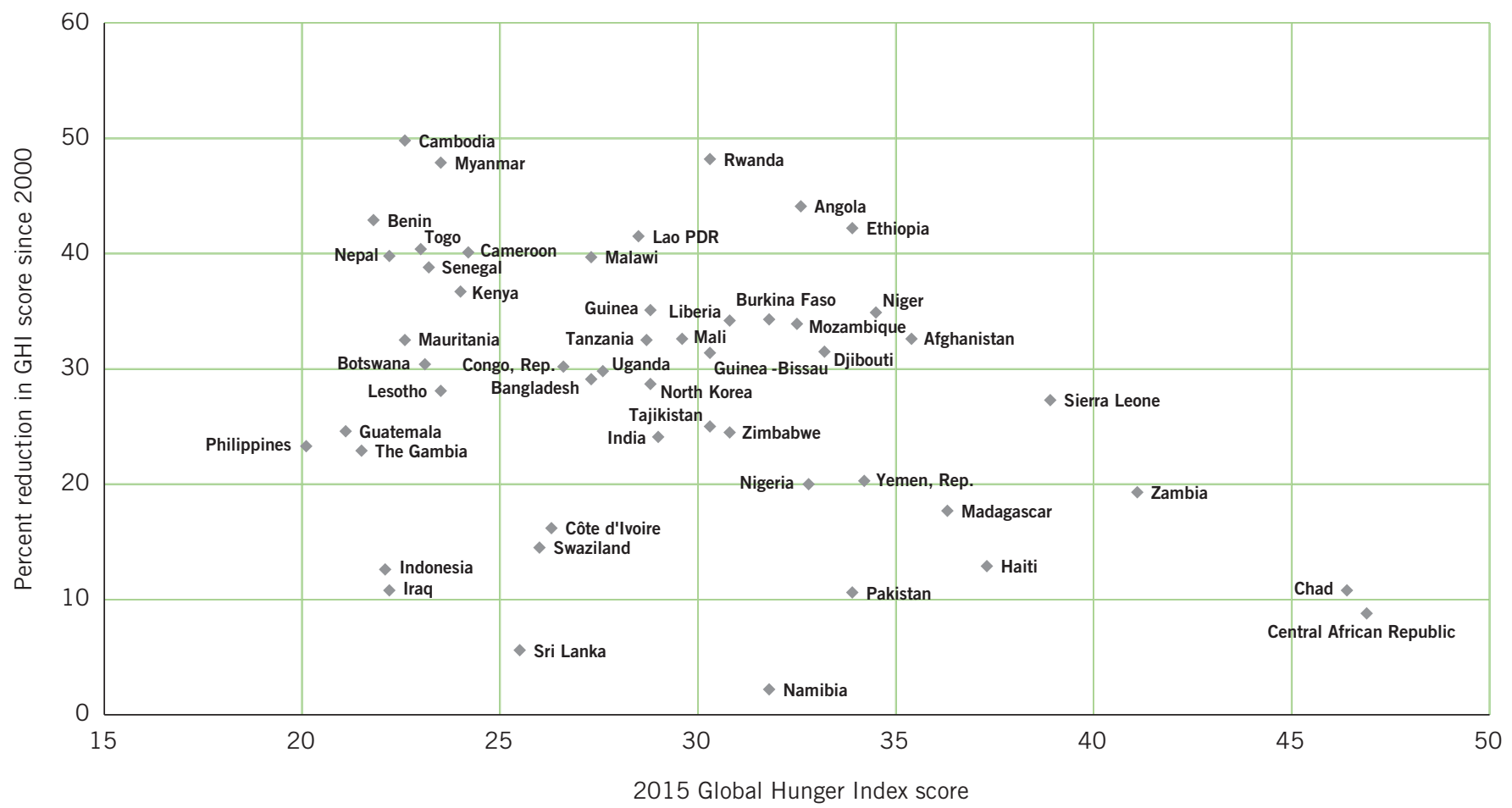

Note: The countries included are those with $2015 \mathrm{GHI}$ scores equal to or greater than 20 , reflecting either serious or alarming hunger levels. This figure features countries where data were available to calculate GHI scores. Some likely poor performers may not appear, due to missing data.

Eight countries still suffer from levels of hunger that are alarming. The majority of those are in Africa south of the Sahara. The three exceptions are Afghanistan, Haiti, and Timor-Leste. In last year's $\mathrm{GHI}$ report, based on the previous GHI formula, two countries had extremely alarming $2014 \mathrm{GHI}$ scores-Burundi and Eritrea. Scores could not be calculated for these countries this year due to lack of data on undernourishment, but it is likely that they persist as hunger hot spots.

While no countries had extremely alarming levels of hunger (GHI scores of 50 points or more) according to $2015 \mathrm{GHI}$ scores, many countries crossed this threshold in the reference years of this report-1990, 1995, 2000, and 2005. Examples of countries with extremely alarming hunger levels as recently as 2000 include Afghanistan, Niger, and Sierra Leone, to name but a few. That many countries now have less severe hunger ratings than they did in the past testifies to the progress made.

The Central African Republic, Chad, and Zambia have the highest $2015 \mathrm{GHI}$ scores. Coupled with low percentage reductions in hunger levels since 2000, these countries merit our attention (Figure 2.3). The Central African Republic has been plagued by instability, dictatorships, and repeated coups since its independence from France in
1960. Most recently, beginning in 2013 , fighting between disparate groups resulted in sizeable casualties and internal displacement of nearly 20 percent of the population (Arieff 2014).

Chad, too, has experienced instability in recent decades, due in part to conflicts with its neighbors and the influx of refugees from neighboring countries, such as Sudan and the Central African Republic (IDMC 2014). Zambia, on the other hand, has been relatively peaceful and democratic in recent history. Yet economically, the country is extremely poor and is heavily dependent on copper mining, which has led researchers to describe Zambia as an example of a country beset by the "resource curse" (Boos and Holm-Müller 2015). Resource curse theory posits that countries with abundant natural resources are plagued by slow growth (Sachs and Warner 2001), as well as inequality and poverty (Humphreys, Sachs, and Stiglitz 2007).

In terms of the GHI components, Haiti, Zambia, and the Central African Republic have the highest proportion of undernourished people, between 48 percent and 53 percent of the population. TimorLeste, Burundi, and Eritrea have the highest prevalence of stunting (low height for age), with more than 50 percent of children under age five suffering from stunting. South Sudan, Djibouti, and Sri Lanka have the highest prevalence of wasting (low weight for height), 


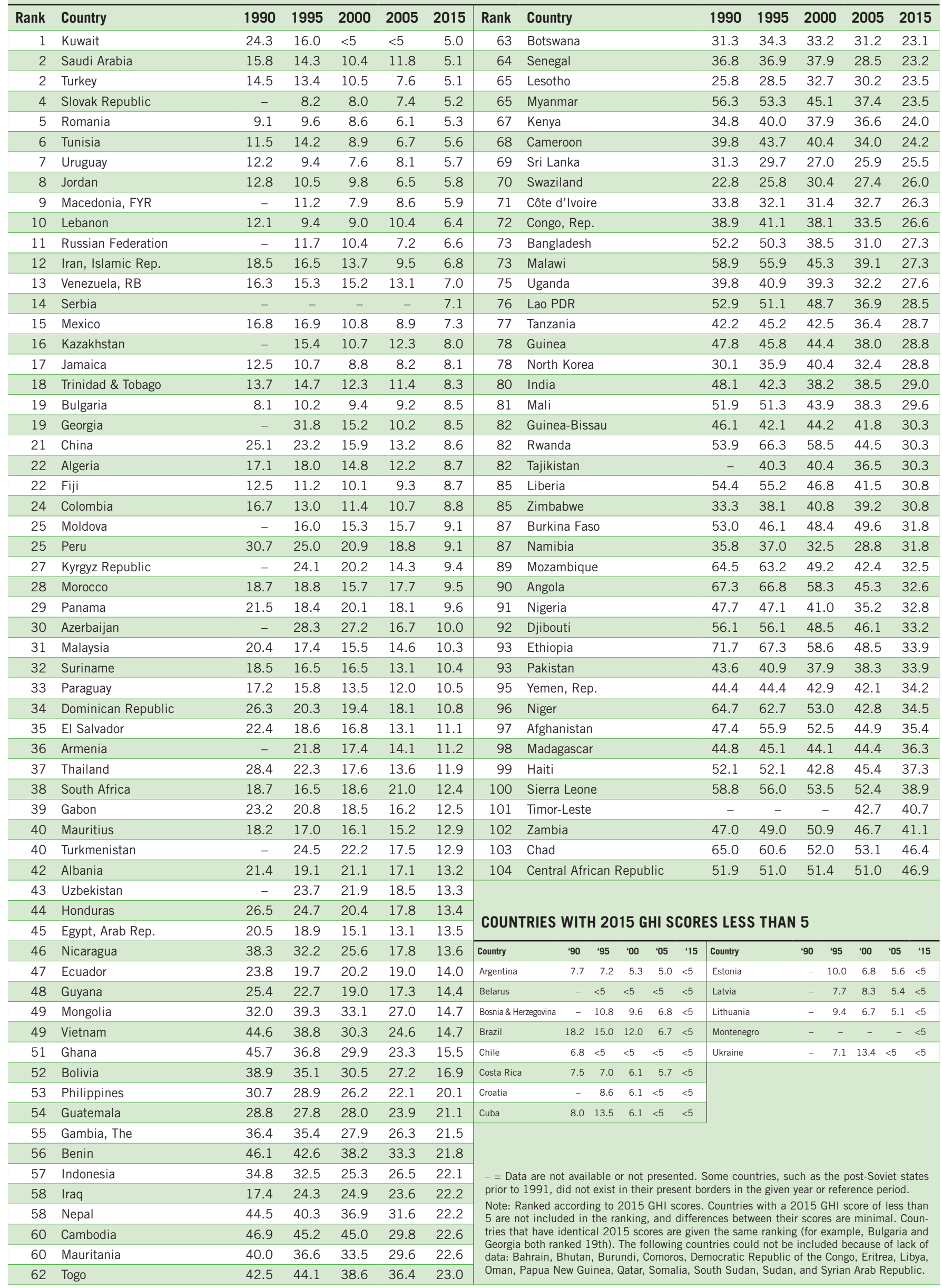


with between 21 percent and 23 percent of children under age five affected. Angola, Sierra Leone, and Chad have the highest underfive mortality rates, ranging between 15 percent and 17 percent.

This year's report does not include GHI scores for several countries that had very high (alarming or extremely alarming) GHI scores in the 2014 report, including Burundi, Comoros, Eritrea, South Sudan, and Sudan, because current data on undernourishment were not available. ${ }^{5}$ In addition, while the Democratic Republic of the Congo had the highest GHI score of all countries in the $2011 \mathrm{GHI}$ report, it has not been possible to calculate a GHI score for the country since
2011 due to missing data. GHI scores have never been calculated for Somalia due to data constraints, yet the World Food Programme considers it one of the most food insecure countries in the world (WFP 2015b). Although the lack of data obscures their hunger levels, the situations in these countries still merit great concern and must not be forgotten.

5 In the $2014 \mathrm{GHI}$, scores for South Sudan and Sudan were calculated together as the former
Sudan. In the $2015 \mathrm{GHI}$, Sudan and South Sudan are reported separately because all organi-
zations that provide data on the component indicators now report them as separate countries. 


\section{FIGURE 2.4 2015 GLOBAL HUNGER INDEX BY SEVERITY}

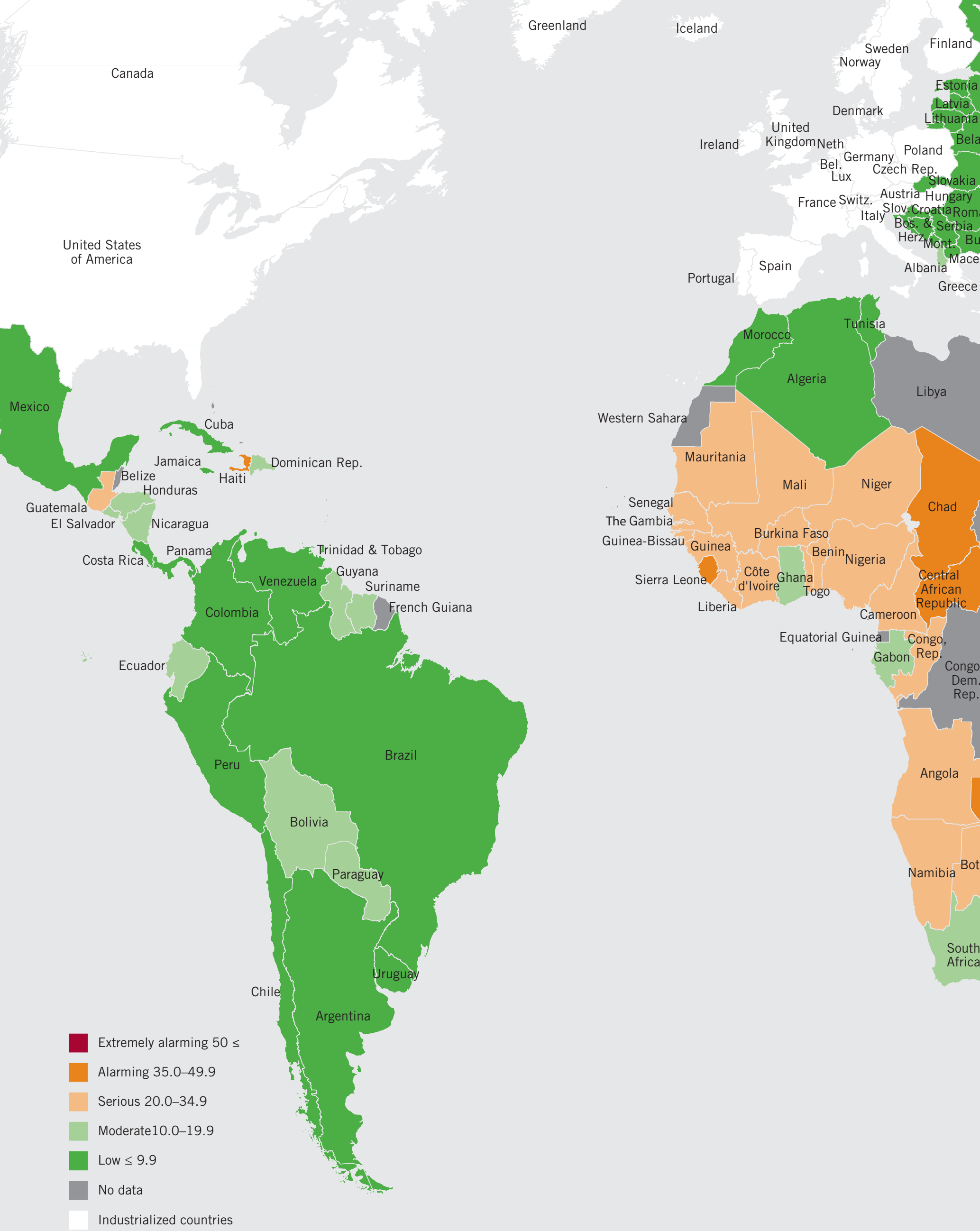





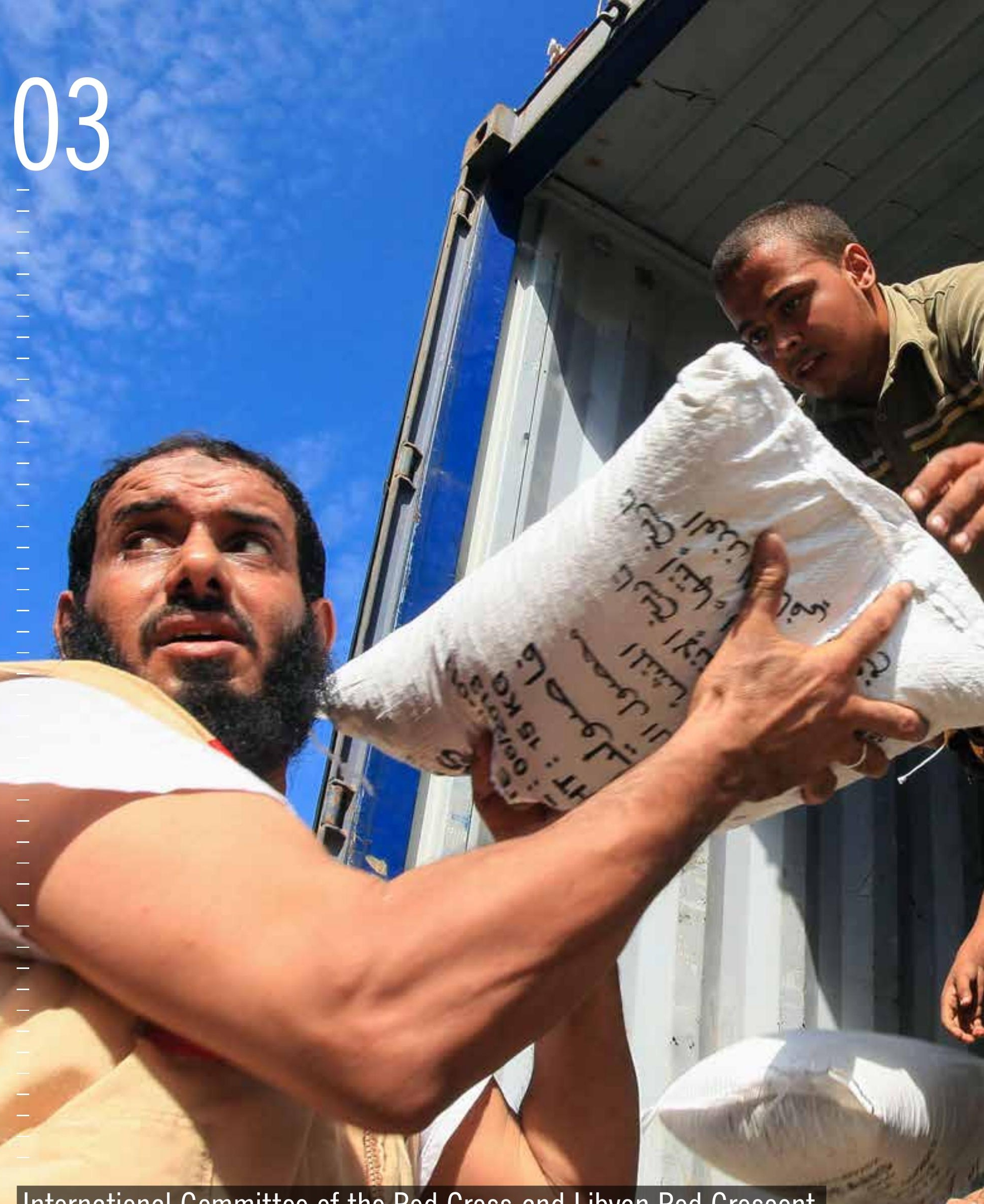

International Committee of the Red Cross and Libyan Red Crescent staff unload food and other goods for displaced people in Swaoh, Libya. Ongoing civil conflict and violence between rival militias have forced more than 500,000 people to flee their homes. 


\section{ARMED CONFLICT AND THE CHALLENGE OF HUNGER: IS AN END IN SIGHT?}

\section{Alex de Waal}

War and famine, two fearsome horsemen, have long ridden side by side. Armed conflict disrupts food systems, destroys livelihoods, displaces people, and leaves those who do not flee both terrified and unsure when they will eat their next meal.

News stories and scholarly articles on conflict and hunger are usually pessimistic, assuming both are inevitable parts of the human condition. But a review of trends offers cause for optimism: a potential end to famine and conflict-induced starvation by 2030 . This chapter examines those trends, identifies vulnerable populations, explores the complex relationship between conflict and hunger, and underscores what must be done to eliminate famine for good.

\section{Invisible Victims}

When famine or acute hunger occurs today, it is usually the result of armed conflict. The best estimate for the number of people currently affected by conflict is 172 million (CRED 2013). Although refugees are more visible, 87 percent of those affected by conflict are actually residents who do not flee their homes - and who tend to fare even worse than those displaced (CRED 2013). Beyond the reach of aid agencies, they suffer in silence.

Victims of violence in ostensibly peaceable countries are a more vast and less visible group of hungry people. They include victims of violent crime, gang violence, brutality by state enforcement bodies, and intimate partner violence-which together account for the vast majority of violence globally (Geneva Declaration 2011). Of the estimated 780,000 people who died worldwide from violence and its immediate effects each year between 2004 and 2009, 66 percent were killed in nonconflict settings (mainly due to crimes), 27 percent died from hunger and disease due to conflict, and just 7 percent died as a direct consequence of war. Of the 14 countries with annual rates of violent deaths of more than 30 per 100,000, just six were engaged in war. The other eight-with El Salvador topping the list—suffer high rates of violent crime. The impact of all of these forms of violence on development is major and severe; their victims are poorer, more vulnerable, and hungrier than others (World Bank 2011).

Survivors of war are another under-recognized population that is vulnerable to food insecurity. Violent deeds live on, not only in the psychological trauma suffered by survivors and their family members, but also in basic well-being. Recent studies from Uganda on the longterm impact of war wounds and trauma show that affected households are hungrier, sicker, and less well off than others (Mazurana et al. 2014). Meeting the needs of survivors constitutes another vast and often overlooked welfare and food policy challenge.

\section{The End of Calamitous Famines}

While more must be done to address the unique situations these invisible groups face, great progress has been made. Yet we are often so focused on the problems of the present, it is easy to overlook vast changes that have occurred over the long term. For example, the historic declines in all kinds of violence (Pinker 2012) and the reduction in the frequency and lethality of armed conflict (Human Security Report Project 2013) are often obscured by crises of the moment.

Much the same is true for famine. Indeed it is all too easy to overlook historic, but unheralded achievements of the last 50 years: the elimination of calamitous famines (those that cause more than 1 million deaths) and the reduction almost to a vanishing point of great famines, or those that cause more than 100,000 deaths (Howe and Devereux 2004).

Until the middle of the 20th century, the drumbeat of starvation was constant, with millions dying every decade. Between 1870 and 2014, 106 episodes of famine and mass starvation each killed 100,000 people or more (Mallory 1926; Newman 1990; Devereux 2000; Dyson and Ó Gráda 2002).

The trends are striking (Figures 3.1 and 3.2). During the 20th century, the death toll from great famines zigzagged, ranging from a 10-year high of 27 million in 1900-1909; to more than 15 million in each of the 1920s, 1940s, 1950s, and 1960s; to a low of 1.4 million during the 1990s. In the 21 st century thus far, the death toll is near 600,000 .

FIGURE 3.1 GLOBAL DEATH TOLL FROM GREAT FAMINES, 1870s-2010s

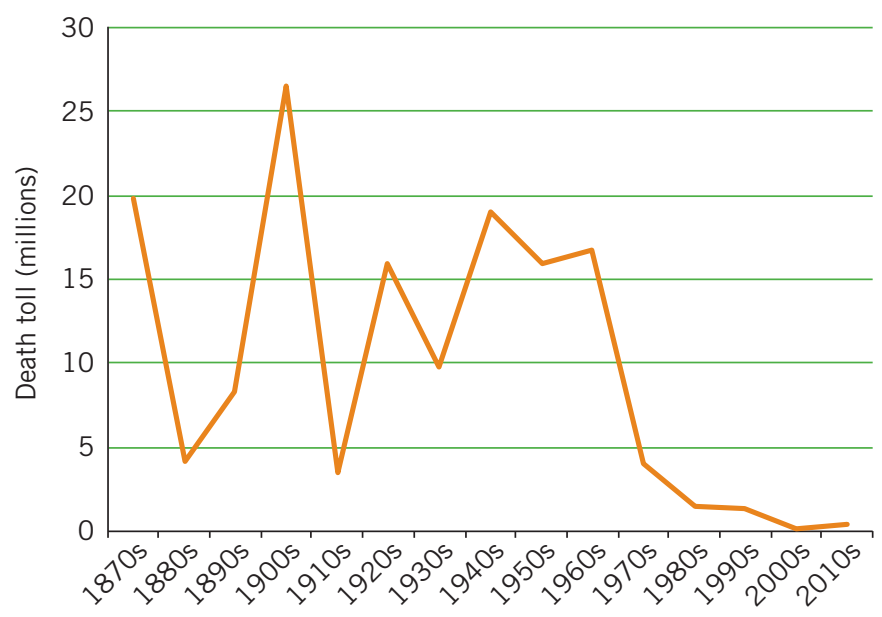

Note: Each great famine killed more than 100,000 people. Source: World Peace Foundation (2015).

Note: The views expressed in this chapter are those of the author. They do not necessarily reflect the views of IFPRI, Welthungerhilfe, or Concern Worldwide. 
Taking a closer look at the history behind the graphs, we see famines associated with the Age of Empire from the 1870s to World War I (Hobsbawm 1989). Famines killed tens of millions in South Asia and China, millions in Africa, and smaller numbers in Brazil. The causes: drought and havoc wreaked by imperial conquest and predation, including practices such as dismantling local production systems and imposing a regime of forced labor to produce export crops such as rubber and cotton. With the passing of the most ruthless era of imperial expansion, these famines, also known as "Late Victorian Holocausts," ceased (Davis 2002).

During what historian Eric Hobsbawm (1996) called the "Age of Extremes" from World War I to the end of the Cold War, calamitous famines were caused by totalitarian systems: German and Japanese militarism, Stalinism, and Maoism. Wartime leaders routinely used starvation as a weapon.

Forced collectivization in Ukraine and southern Russia in 19321933 - a possibly genocidal campaign known to Ukrainians as the "Holodomor"- was perhaps the most terrible example of famine as state policy (Conquest 1987). Had the Nazi Hunger Plan to starve 20-30 million Belorussians, Poles, and Ukrainians been fully carried out, it would have been worse still (Lowe 2012). Asian war famines killed many millions from 1936 to 1945 in Bengal, China, Indonesia, and Vietnam.

After World War II, Communist policies caused horrific famines. Thirty million people died in the Chinese famine of 1958-1962, caused by Mao Zedong's Great Leap Forward (Becker 1996). The Khmer Rouge starved 1.5 million Cambodians in the 1970s (Kiernan 2008). These calamitous famines ended along with "faminogenic" regimes, such as totalitarian governments and wars of extermination (Marcus 2003). The last great Communist famines were in Ethiopia in 1983-1985, when collectivization and hunger as a weapon of war collided with drought, killing up to 1 million (de Waal 1997), and in North Korea in 1996-1997, when a food crisis killed 500,000600,000 (Goodkind, West, and Johnson 2011).

In the 20th century, Europe and Asia accounted for the vast majority of famine deaths (Figure 3.2). Only two African famines in the last 100 years-Biafra and Ethiopia-have killed as many as 1 million each. Since famine has disappeared from Europe and mostly vanished from Asia, it has lost most of its menace.

And finally, the downward slope of the famines graph (Figure 3.3) contrasts with the upward slope of world population, which rose from about 1.7 billion in 1900 to 7.3 billion today. This surely refutes the pessimism of the early 19th century scholar and cleric Reverend Thomas Malthus, who feared that world population was outpacing the food supply. More than two centuries ago he wrote that "gigantic inevitable famine stalks in the rear [of population growth], and with
FIGURE 3.2 DEATH TOLL FROM GREAT FAMINES, 1870s-2010, BY CONTINENT

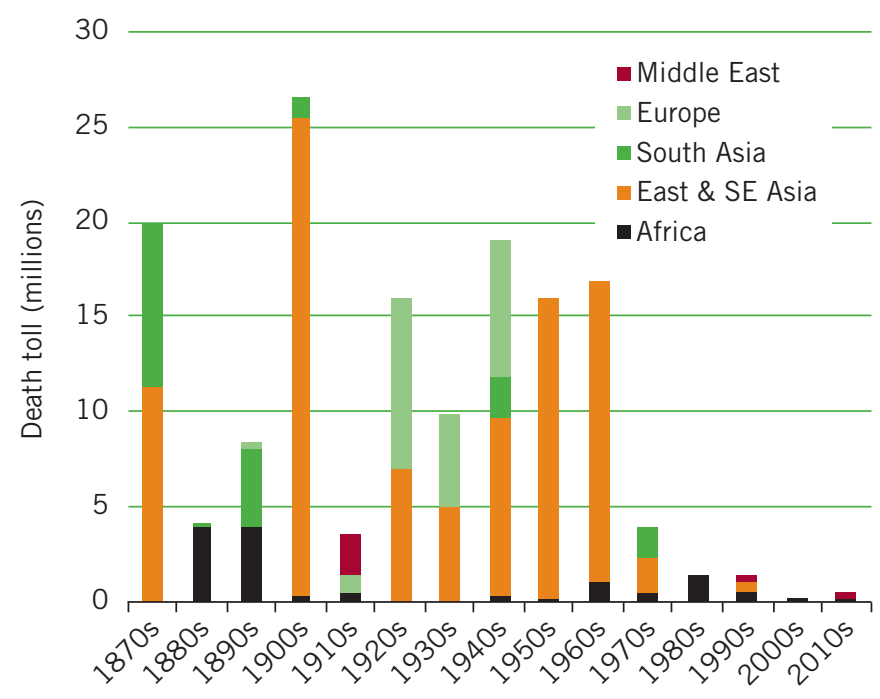

Note: Each great famine killed more than 100,000 people. Source: World Peace Foundation (2015).

one mighty blow, could level the population" (Malthus 1798, 140). In fact, the converse is actually happening.

\section{Positive Developments}

The end of the Cold War, the adoption of international human rights norms, and the rise of globalization are among the key factors that make it possible to eliminate famine for the first time in history. Governments no longer wield the grotesque sovereign privilege to starve their people and tell the rest of the world to mind its own business. Unparalleled global prosperity and interconnectedness, the legitimacy of international concern over domestic violations, and far more informationsharing mean people are less likely to starve in silence because their rulers, or the international community, do not know what is going on.

And the single most important reason an end to famine is within reach? China, once the "land of famine" (Mallory 1926), which suffered more than 80 million famine deaths between 1870 and 1970, or more than half of the global total of 149 million such deaths (World Peace Foundation 2015), has been free of that scourge for half a century.

Most trends are moving in the right direction. In 2013, the Centre for Research on the Epidemiology of Disasters (CRED) reported "encouraging news in terms of lower death rates, indicating that periods of stabilization and humanitarian efforts have succeeded in saving lives" (CRED 2013, 23-24). 
FIGURE 3.3 WORLD POPULATION GROWTH AND DEATH TOLL FROM GREAT FAMINES, 1900-2015

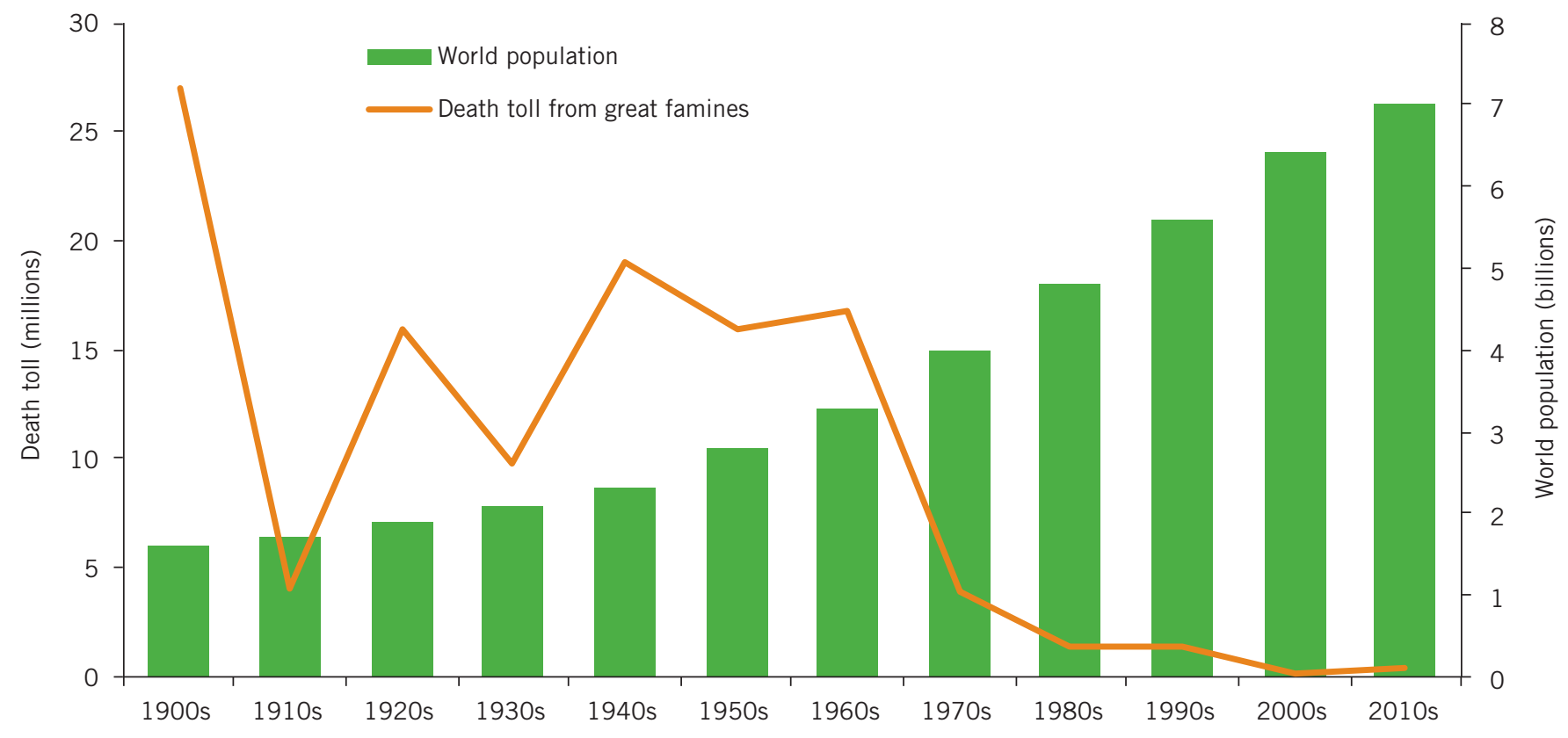

Note: Each great famine killed more than 100,000 people.

Source: US Census Bureau (2013a, 2013b); World Peace Foundation (2015).

\section{Warning Signs}

Malnutrition trends, however, have not been so favorable, with global levels of acute malnutrition (wasting or nutritional edema) rising since 2008, according to CRED's People Affected by Conflict report. This recent upswing coincides with another worrying trend: the reduction in wars has also stalled (Apps 2015; PS21 2015). According to the global think tank, Project for the Study of the 21st Century, the number of conflicts and conflict-related deaths has increased from an all-time low in 2006, but remains well below long-term averages. Between 2013 and 2014, the 20 most conflict-afflicted countries saw violent fatalities rise by 28.7 percent, from 127,134 to 163,562 . Syria is by far the largest contributor, with more than 70,000 deaths in that one year alone. These numbers are still low by historic standards, but they show that much more must be done to win the battle against war and hunger.

\section{New Wars, New Famines}

Today's famines are "complex humanitarian emergencies," caused mostly by armed conflict and exacerbated by natural disasters or international policies (Keen 2008). These "new wars" (Kaldor 1999) involve not only state armies and insurgents, but also paramilitaries and ethnic militia, criminal gangs, mercenaries, and international forces. Most new wars are civil wars, which increasingly spill over borders, disrupt livelihoods and food systems, and force people to flee. They tend to be less lethal than old wars, both in violence and in hunger (Human Security Report Project 2013). But they are often intractable and display persistent, seemingly patternless violence from which no one is safe.

In previous eras, governments and rebels controlled humanitarian access. They either permitted it and protected aid workers, or they blocked access. Today, humanitarian workers face greater personal dangers as they navigate a more dangerous micro-terrain of warfare, village by village. Under these circumstances, getting food aid to those in need demands exceptional skills, and the riskier conditions can result in "new famines" (Devereux 2007). A selection of cases illustrates how such famines arise:

$\rightarrow$ SUDAN. In 2003-2004, armed conflict between the Sudanese military and various rebel groups in Darfur led to an estimated 200,000 civilian deaths through hunger, disease, and displacement (US GAO 2006). An extreme case occurred in the small village of Keilak in April 2004, where a visiting UN team found that overall death rates were more than 40 times the standard threshold for declaring an emergency. This episode was thankfully 
isolated. And as soon as the UN raised the alarm, the local commander's siege was ended and aid provided.

$\rightarrow$ SomaliA. The famine in Somalia in 2011-2012 was the worst of the century thus far, costing an estimated 250,000 lives (Maxwell and Majid 2015). It was a complex emergency: drought, economic crisis, and war all contributed. Politics complicated the dynamics of the hunger situation. Humanitarian agencies had to contend not only with restrictions on access and the risks of kidnapping and violence, but also US counterterrorism legislation impeded their operations in insurgent-controlled areas. The UN did not raise the alarm until famine conditions were already widespread. In 2014-2015, similar factors resulted in acute hunger in the parts of Syria and Iraq that are controlled by the Islamic State, and the starvation of the Yazidi minority.

$\rightarrow$ DEMocratic RePublic OF THE Congo. Since 1996, wars in the Democratic Republic of the Congo have led to an immense humanitarian disaster, with estimates of deaths ranging as high as 5.4 million people (International Rescue Committee 2008). These deaths are overwhelmingly caused by hunger and disease associated with the collapse of health services and other basic infrastructure, along with disruptions to employment and food markets.

$\rightarrow$ IRAQ. In the 1990s the Iraqi people suffered from a lethal combination of Saddam Hussein's depredations, comprehensive sanctions, and Hussein's use of the food rationing system to reward his loyal followers and thereby maintain his power base (Alnasrawi 2000). Between 250,000 and 500,000 children died of hunger and disease (UNICEF 1999).

Even when food was used as a weapon, recent conflicts did not necessarily result in major famine. For example, in its final offensive against the Tamil Tigers in 2009, the Sri Lankan government withheld aid to a besieged and hungry civilian population (International Crisis Group 2010). Nonetheless, the government's final victory was swift and the possibility of a protracted Biafra-style siege was foreclosed. At its peak in 2008-2009, the Israeli siege of Gaza involved tight control of basic supplies to the territory. The UN was permitted to transport just a fraction of the assistance it considered necessary for humanitarian purposes (Cook 2012). The deprivation suffered by the Gazans was extreme, but apparently stopped short of crossing the line into mass starvation. Dov Weisglass, an adviser to Ehud Olmert, the Israeli Prime Minister, reportedly said, "The idea is to put the Palestinians on a diet, but not to make them die of hunger" (Urquhart 2006).

\section{Does Hunger Lead to Conflict?}

Conflict and hunger are strongly associated. The countries with the lowest levels of food security, according to the 2014 Global Hunger Index, are engaged in or recently emerged from war, including Burundi, Comoros, Eritrea, Sudan and South Sudan, and Timor Leste (von Grebmer et al. 2014).1,2 More strikingly, while most countries have marked significant 25-year gains in objective hunger measures, a handful have stagnated or deteriorated-notably Burundi, Comoros, Iraq, and Sudan (all conflict-affected) and Swaziland, scarred by the world's worst HIV/AIDS epidemic (Whiteside and Henry 2011). In contrast, hunger is retreating in Ghana and Rwanda, which are relatively peaceful.

It is clear that conflict is the main cause of persistent severe hunger. Might hunger-whether in the form of famine, chronic malnutrition, or general deprivation-also be a factor that drives conflict? Possibly, but it's less likely.

Synthesizing more than a decade of controversy about the causes of armed conflict-a debate widely known as "greed or grievance" (Collier and Hoeffler 2004) — the World Bank's 2011 World Development Report concluded that there is no simple causal explanation for conflict (World Bank 2011). Conflict has many sources (Box 3.1). Many economic factors make countries vulnerable to lapsing into civil war. The good news is that as governance improved over the past few decades, conflict, poverty, and hunger have all consistently declined. Unfortunately, the trajectories have been uneven. Worse yet, more recent evidence suggests that progress has stalled.

While major famine and war have virtually disappeared in East Asia and Southeast Asia, the Middle East has seen an increase in both armed violence and hunger over the last five years. Africathe poorest and most conflict-prone continent-faces the greatest risk. Many affected countries are prone to authoritarianism and violent competition, due to "resource curse" economies that rely heavily on the exploitation of natural resources, especially minerals, to speed up economic growth (Kaldor, Karl, and Said 2007). The "great African land-grab" (Cotula 2013) — in which local elites and foreign corporations are taking the land from millions of smallholders-is contributing to deep human insecurity and grievance, which has led to both nonviolent and violent resistance in countries as diverse as Ethiopia and Sierra Leone.

\section{Hunger's Destabilizing Effect}

Hunger is somehow different from other human stresses. Food and famine strike a deep emotive chord, even among people who have never

\footnotetext{
1 The 2014 GHI score could be calculated for only former Sudan as one entity, because separate undernourishment estimates for 2011-2013 were not available for South Sudan, which became independent in 2011, and present-day Sudan.

2 For most of these war-torn countries, 2015 GHI scores could not be calculated due to lack of data.
} 


\section{BOX 3.1 MULTIPLE SOURCES OF CONFLICT}

The causes of conflict are complex, nonlinear, and mediated by a host of factors, including political institutions and economic structures (World Bank 2011). A spectrum of threats to human security - assaults on community, livelihoods, and basic welfare - provide a common thread that explains why people resort to violence. Hunger certainly figures among the causes, but how it plays out varies by context.

Such complexity means we must be exceptionally careful when drawing conclusions about any one driver of conflict. In countries such as Afghanistan, Colombia, Congo, Sudan, or Yemen, patterns of violence are turbulent. Like the waters of a fast-flowing mountain stream, they are chaotic from one moment to the next, but retain a recognizable structure over time. If a researcher takes the data for violence in any particular country over any particular period of time, feeds them into a computer, and looks for correlations with weather patterns, market prices, malnutrition levels-or any other indicator-some correlation will always arise. However, most of these associations fade away upon closer scrutiny (Buhaug et al. 2014). Too often, though, researchers' disclaimers about the uncertainty of their findings are set aside when their findings are synthesized or popularized.

personally faced starvation. Around the world, people believe that a government that cannot feed its people has forfeited its legitimacy.

High bread prices famously brought out revolutionary mobs in Paris in 1789 (Grove 1998; Neely 2007). The 1943 Bengal famine discredited the British Raj, undermining its promise to prevent starvation (Drèze 1991). Famine in Wollo Province undermined the rule of Ethiopia's Emperor Haile Selassie in 1973-1974, and Sudanese President Jaafar Nimeiri's failure to provide drought relief in 1985 helped bring down his government (Article 19 1990; de Waal 1997). After Cyclone Bhola, the deadliest storm in the last 100 years, struck East Bengal in 1970, the slow and inadequate response of Pakistan's Ayub Khan government to hunger and deprivation helped mobilize the Bangladesh independence movement (Sommer and Mosley 1972; Hossain 2010).

More recently, food protests helped bring down the Haitian government in 2008, and food price rises coincided with protests during the Arab Spring of 2011 (Brinkman and Hendrix 2011). Protests are more likely to lead to political violence in fragile states (World Bank 2011). The pathways from food scarcity to protest are complex and unique to each case, but a common thread runs through these examples. Food security is not only an essential component of human well-being, but also a foundation for political stability. Governments jeopardize food security at their peril.

\section{Standing Firm}

Despite failing to keep hunger at bay, some governments carry on regardless. The Myanmar government presided over devastation caused by Cyclone Nargis in 2008, which drowned an estimated 138,000 people and left nearly 2 million without shelter, drinking water, or basic food items (Guha-Sapir and Vogt 2009). Fearing an increased international presence during a referendum on the new constitution, Myanmar refused to initiate or allow substantive aid into the country for two weeks (Zarni 2015). Rulers such as China's Mao Zedong, North Korea's Kim Jong-II, and Ethiopia's Mengistu Haile Mariam stayed in power, oblivious to human suffering. They even used deprivation and controlled food supplies to consolidate power (Becker 1996; Natsios 2001; de Waal 1997). While failing to address severe hunger and deprivation does not necessarily lead to the downfall of governments, a sound food security policy is good political insurance.

From these threads we can underline the generally positive conclusion that hunger may pose less of a threat to peace than it has in the past. And there is no reason why natural disasters must cause either famine or political crisis (Box 3.2).

\section{Looking Ahead}

The last decades of the 20th century saw the end of calamitous famines, which kill one million or more people. But what will it take to eliminate famine and acute hunger, or starvation, by 2030?

Two tasks stand out for eliminating conflict-related hunger. First, we need stronger mechanisms to prevent and resolve conflicts. With wars becoming fewer and less lethal, the long-term trends for violent conflict are actually encouraging (Human Security Report Project 2013). But progress appears to have stalled, and the challenges of the day - for example in South Sudan, Syria, and Yemen-are formidable. Second, we must activate the international emergency relief system to dispatch large-scale food aid where it is needed most.

\section{Political Commitment}

We need political leadership to strengthen international food security policy. This depends on political decisions in western capitalsand these are not always easy to make. While the United Nations 


\section{BOX 3.2 GLOBAL WARMING, CONFLICT, AND HUNGER}

There is no question that climate-related disasters are increasing in number and severity (Guha-Sapir, Hoyois, and Below 2014). As a consequence, should we expect to see more conflicts, and therefore more hunger?

One area in which methodological sobriety is much needed is conflict and the environment. The big picture on climate change, hunger, and conflict is encouraging thus far. Over the past five decades, even as global warming has advanced and natural disasters have become more frequent and damaging, both wars and hunger have decreased.

At the country level, despite fears that the coming century would be marked by "water wars," transboundary river basins ranging from the Indus to the Jordan, in fact, show more cooperation than conflict (Islam and Susskind 2013). The March 2015 agreement between Ethiopia, Egypt, and Sudan that defined principles for sharing the Nile waters illustrates this positive turn of events.

At the local level, the picture is not encouraging. East African data show that extreme rainfall variation in either directionboth too much or too little-increases conflict risks (Raleigh and Kniverton 2012). Fluctuations in livestock prices and changes in local seasonal migrations, which are both influenced by rainfall, are associated with risks of violence (Maystadt, Calderone, and You 2014; Maystadt and Ecker 2014). But to extrapolate these findings to wider predictions is not warranted. The effects are arguably well within the turbulent parameters of normal local conflict and should not be seen as harbingers of bigger wars to come.

Recent attempts to identify climate change as a driver of large-scale armed conflict have been effectively criticized, with the plea that connections are complicated (Raleigh, Linke, and O'Loughlin 2014). Recent studies disagree on both the magnitude of the impact of climate change on conflict and the direction of the effect. One noted that "research to date has failed to converge on a specific and direct association between climate and violent conflict" (Buhaug et al. 2014, 394-395).

To understand the dynamics of extreme weather and conflict, we should not lose sight of the role of political leaders. For example, did the protracted drought in Syria from 2006-2010 help spark the conflict that erupted in 2011? One researcher, Francesca de Châtel, argues that government policies, including bureaucrats' long-term mismanagement of natural resources, were to blame (de Châtel 2014). Their focus on dam construction and irrigation projects in the northeast meant that small farmers in that area were neglected, impoverished, and angry.

Another problem was the government's failure to respond to the humanitarian crisis and food price increases. This was one of many grievances that triggered protests in March 2011. De Châtel vigorously challenges those who see a strong causal link, writing: "The possible role of climate change in this chain of events is not only irrelevant, it is also an unhelpful distraction and a damaging alibi for the Assad regime's failings" (de Châtel 2014, 532). Other climate researchers' findings on Syria detail the gravity of drought and groundwater depletion, and suggest that these elements might have contributed to the 2011 unrest (Kelley et al. 2015).

The relationship between environmental disasters and conflict is highly nuanced. According to researchers at London's Overseas Development Institute, "natural disasters reduce some conflict drivers while exacerbating others" (Harris, Keen, and Mitchell 2013). Disaster and government failures to respond can deepen existing societal tensions, while disruption presents economic opportunities for criminal activities. Crisis often offers opportunities to advance militant or divisive political agendas. And disasters can make conflicts more likely by altering the balance of power or a warring party's ability to misappropriate aid. and the European Union can do much to unlock a humanitarian response, the role of the US government is pivotal, especially in politically controversial cases. With its continuing cereal surpluses, which are the backbone of global food aid, its agenda-setting role at the UN Security Council, and its power to impose financial and legal sanctions on those who violate its counterterrorism legislation, the United States remains the "veto holder" with regard to global famine response.
When the first signs of famine in North Korea became apparent to the world in 1997, a vigorous debate took place in US newspapers. Some argued that it would be wrong to condition aid on policy change by the regime, notwithstanding its culpability for the famine. Others implicitly made the case for starving North Korea into collapse, claiming that aid would ultimately be used to support the military apparatus of a government hostile to both its own people and to the United States. In the pro-aid group, Andrew Natsios, 
who later became administrator of the US Agency for International Development (USAID) in 2001-2006, observed that US aid helped make the regime more open to the international community and that no totalitarian dictator has ever been overturned during or after a famine (Natsios 2001).

Natsios was tasked with making good on President George W. Bush's promise of "no famine on my watch." Perhaps USAID's most remarkable but under-recognized act in those years was initiating a relief program for Darfur in September 2003_six months before the humanitarian crisis became headline news. Natsios made this decision well aware that he would be open to the same critique made when the United States aided North Korea. Regardless, he did the right thing. Food aid undoubtedly saved many thousands of Darfurian lives.

While the United Nations and powerful governments can predict and stop major food crises, ultimately the decision is always political. Faced with an imminent famine in Somalia in 2011, the US government failed to override its antipathy to al-Shabab and waited until famine was well advanced to authorize assistance (Maxwell and Majid 2015). Behind the scenes, US counterterrorism legislation made it impossible for UN agencies and nongovernmental organizations to operate in al-Shabab-controlled areas. To do so would be to risk being accused of supporting a terrorist organization. Only when the United Nations moved to declare famine in Somalia was the United States ready to respond and allow others to do so without automatically running afoul of its prohibition on supporting terrorism.

The lesson is clear: Political commitment at the highest levels to prevent famine, no matter what the political context, is needed. Countries in need should be aided, regardless of their standing with any other government.

In closing, while the elimination of calamitous famines and the foreseeable end of great famines are tremendous achievements, the work of conquering acute and chronic hunger is not finished. Economic development, better food policy, conflict resolution, and international humanitarian response will all continue to play roles in this venture. Unless armed conflicts can be reduced-and preferably ended-and the many invisible victims of violence can be reached with better humanitarian action and welfare policy, the gains will not last. 
DATA SOURCES FOR THE GLOBAL HUNGER INDEX COMPONENTS, 1990, 1995, 2000, 2005, AND 2015

\begin{tabular}{|c|c|c|c|c|}
\hline GHI & $\begin{array}{l}\text { Number of } \\
\text { countries with } \\
\text { GHI }\end{array}$ & Indicators & Reference years & Data sources \\
\hline \multirow[t]{4}{*}{1990} & 96 & Percentage of undernourished in the population ${ }^{\mathrm{a}}$ & $1990-1992^{b}$ & FAO 2015 and authors' estimates \\
\hline & & Percentage of wasting in children under five & $1988-1992^{\circ}$ & $\begin{array}{l}\text { UNICEF/WHO/World Bank 2015; } \\
\text { WHO 2015; ' and authors' estimates }\end{array}$ \\
\hline & & Percentage of stunting in children under five & $1988-1992^{\circ}$ & $\begin{array}{l}\text { UNICEF/WHO/World Bank 2015; } \\
\text { WHO 2015; d and authors' estimates }\end{array}$ \\
\hline & & Under-five mortality & 1990 & IGME 2014 \\
\hline \multirow[t]{3}{*}{1995} & 115 & Percentage of undernourished in the population ${ }^{\mathrm{a}}$ & $1994-1996^{b}$ & FAO 2015 and authors' estimates \\
\hline & & Percentage of wasting in children under five & 1993-1997• & $\begin{array}{l}\text { UNICEF/WHO/World Bank 2015; } \\
\text { WHO 2015; UNICEF 2009; 'd and authors' estimates }\end{array}$ \\
\hline & & Percentage of stunting in children under five & 1993-1997• & $\begin{array}{l}\text { UNICEF/WHO/World Bank 2015; } \\
\text { WHO 2015; UNICEF 2009; 'd and authors' estimates }\end{array}$ \\
\hline \multirow[t]{4}{*}{2000} & 115 & Percentage of undernourished in the population & $1999-2001^{b}$ & FAO 2015 and authors' estimates \\
\hline & & Percentage of wasting in children under five & $1998-2002^{f}$ & $\begin{array}{l}\text { UNICEF/WHO/World Bank 2015; } \\
\text { WHO 2015; d and authors' estimates }\end{array}$ \\
\hline & & Percentage of stunting in children under five & $1998-2002^{f}$ & $\begin{array}{l}\text { UNICEF/WHO/World Bank 2015; } \\
\text { WHO 2015; 'd and authors' estimates }\end{array}$ \\
\hline & & Under-five mortality & 2000 & IGME 2014 \\
\hline \multirow[t]{4}{*}{2005} & 116 & Percentage of undernourished in the population ${ }^{\mathrm{a}}$ & $2004-2006^{b}$ & FAO 2015 and authors' estimates \\
\hline & & Percentage of wasting in children under five & $2003-2007 \mathrm{~g}$ & $\begin{array}{l}\text { UNICEF/WHO/World Bank 2015; UNICEF 2013; UNICEF 2009; ‘ and authors' } \\
\text { estimates }\end{array}$ \\
\hline & & Percentage of stunting in children under five & 2003-20078 & $\begin{array}{l}\text { UNICEF/WHO/World Bank 2015; UNICEF 2013; UNICEF 2009; ' and authors' } \\
\text { estimates }\end{array}$ \\
\hline & & Under-five mortality & 2005 & IGME 2014 \\
\hline \multirow[t]{3}{*}{2015} & 117 & Percentage of undernourished in the population ${ }^{\mathrm{a}}$ & $2014-2016^{b}$ & FAO 2015 and authors' estimates \\
\hline & & Percentage of stunting in children under five & $2010-2014^{\mathrm{h}}$ & $\begin{array}{l}\text { UNICEF/WHO/World Bank 2015; } \\
\text { WHO 2015; Measure DHS 2015; UNICEF 2015; India, Ministry of Women and } \\
\text { Child Development, and UNICEF, India 2014; }{ }^{\text {d }} \text { and authors' estimates }\end{array}$ \\
\hline & & Under-five mortality & 2013 & IGME 2014 \\
\hline
\end{tabular}

a Proportion of the population with chronic calorie deficiency.

b Average over a three-year period. Data for 2014-2016 are provisional estimates.

- Data collected from the year closest to 1990; where data for 1988 and 1992, or 1989 and 1991, were available, an average was used.

d UNICEF/WHO/World Bank 2015 data are the primary data sources, and WHO 2015; UNICEF 2015, 2013, and 2009; and MEASURE DHS 2015 are complementary data sources. For India's 2015 GHI score, data on stunting and wasting in children were provided by India, Ministry of Women and Child Development, and UNICEF, India. e Data collected from the year closest to 1995; where data for 1993 and 1997, or 1994 and 1996, were available, an average was used.

' Data collected from the year closest to 2000; where data for 1998 and 2002, or 1999 and 2001 , were available, an average was used.

8 Data collected from the year closest to 2005; where data for 2003 and 2007, or 2004 and 2006, were available, an average was used.

$\mathrm{n}$ The latest data gathered in this period. 


\begin{tabular}{|c|c|c|c|c|c|c|c|c|c|c|c|c|c|c|c|c|c|c|c|c|}
\hline \multirow[t]{2}{*}{ Country } & \multicolumn{5}{|c|}{$\begin{array}{l}\text { Proportion of undernourished } \\
\text { in the population (\%) }\end{array}$} & \multicolumn{5}{|c|}{$\begin{array}{l}\text { Prevalence of wasting in } \\
\text { children under five years (\%) }\end{array}$} & \multicolumn{5}{|c|}{$\begin{array}{l}\text { Prevalence of stunting in } \\
\text { children under five years (\%) }\end{array}$} & & der-five & mortali & ty rate ( & (\%) \\
\hline & '90-'92 & '94-'96 & '99-'01 & '04-06 & '14-'16 & '88-'92 & '93-'97 & '98-'02 & '03-'07 & '10-'14 & '88-'92 & '93-'97 & '98-'02 & '03-'07 & '10-'14 & 1990 & 1995 & 2000 & 2005 & 2013 \\
\hline Afghanistan & 29.5 & 45.4 & 45.2 & 35.2 & 26.8 & 11.0 * & 18.2 & 13.7 * & 8.6 & 9.5 & 50.0 * & 53.2 & 55.2 * & 59.3 & 40.9 & 17.9 & 14.9 & 13.6 & 11.9 & 9.7 \\
\hline Albania & 8.5 * & 4.1 * & 6.1 * & 11.2 * & 8.5 * & 8.8 * & 9.3 * & 12.2 & 7.3 & 7.2 * & 37.9 * & 38.3 * & $\begin{array}{l}* 39.2 \\
\end{array}$ & 27.0 & 17.8 * & 4.1 & 3.3 & 2.6 & 2.0 & 1.5 \\
\hline Algeria & 7.7 & 7.7 & 8.7 & 7.0 & $2.9 *$ & 7.1 & 9.6 & 3.1 & 4.0 & 4.1 & 22.9 & 22.5 & 23.6 & 15.9 & 11.7 & 4.7 & 4.3 & 4.0 & 3.4 & 2.5 \\
\hline Angola & 63.5 & 62.2 & 51.1 & 34.2 & 14.2 & 8.5 * & 8.6 & 9.0 * & 8.2 & 5.9 * & 61.1 * & 61.7 & 47.8 * & 29.2 & 31.5 * & 22.6 & 22.5 & 21.7 & 20.5 & 16.7 \\
\hline Argentina & 2.2 * & 1.2 * & 0.9 * & 1.9 * & 0.2 * & 2.1 * & 2.9 & 1.7 * & 1.2 & 1.6 * & 12.2 * & 12.0 & 8.8 * & 8.2 & 7.7 * & 2.8 & 2.3 & 2.0 & 1.7 & 1.3 \\
\hline Armenia & - & 22.7 & 21.4 & 10.9 & 5.8 & - & 4.6 * & 2.5 & 5.5 & 4.2 & - & 25.6 * & 17.7 & 18.2 & 20.8 & - & 3.9 & 3.0 & 2.3 & 1.6 \\
\hline Azerbaijan & - & 25.4 & 22.5 & 3.7 * & $1.7 *$ & - & 3.8 & 9.0 & 6.8 & 3.1 & - & 28.0 & 24.1 & 26.8 & 18.0 & - & 9.4 & 7.4 & 5.2 & 3.4 \\
\hline Bahrain & - & - & - & - & - & 6.8 & 6.6 & 6.7 * & 6.0 * & 2.8 * & 13.9 & 13.6 & 13.9 * & 11.4 * & 8.5 * & 2.3 & 1.8 & 1.3 & 1.1 & 0.6 \\
\hline Bangladesh & 32.8 & 36.9 & 23.1 & 17.1 & 16.4 & 17.5 & 15.1 & 13.8 & 11.8 & 14.3 & 63.4 & 65.8 & 54.0 & 45.9 & 36.1 & 14.4 & 11.4 & 8.8 & 6.7 & 4.1 \\
\hline Belarus & - & 1.1 * & 2.1 * & 3.0 * & 0.8 * & - & 2.5 * & 2.3 * & 2.2 & 2.2 * & - & 5.5 * & * 4.7 * & 4.5 & 3.7 * & - & 1.8 & 1.4 & 0.9 & 0.5 \\
\hline Benin & 28.1 & 27.5 & 23.9 & 15.9 & 7.5 & 11.9 * & 12.3 & 9.0 & 8.4 & 4.5 & 44.9 * & 39.1 & 39.1 & 44.7 & 34.0 & 17.9 & 15.7 & 14.6 & 11.9 & 8.5 \\
\hline Bhutan & - & - & - & - & - & 5.2 & 5.8 * & 2.5 & 6.0 * & 5.9 & 60.9 & 59.2 * & * 47.7 & 41.4 * & 33.6 & 13.4 & 10.5 & 7.9 & 5.9 & 3.6 \\
\hline Bolivia & 38.0 & 35.3 & 34.6 & 31.1 & 15.9 & 1.5 & 3.6 & 1.6 & 1.7 & 1.6 * & 44.0 & 37.1 & 33.1 & 32.5 & 23.8 * & 12.3 & 10.0 & 7.7 & 5.8 & 3.9 \\
\hline Bosnia \& H & - & 7.3 * & 4.1 * & 2.5 * & 0.9 * & - & $5.2 *$ & 7.4 & 4.0 & 2.3 & - & 15.3 * & 12.1 & 11.8 & 8.9 & - & 1.3 & 0.9 & 0.8 & 0.7 \\
\hline Botswana & 25.1 & 30.1 & 35.6 & 32.8 & 24.1 & 11.0 * & 13.2 & 6.0 & 8.0 * & $5.5 *$ & 41.8 * & 35.1 & 29.1 & 29.2 * & 23.1 * & 5.0 & 6.4 & 8.5 & 6.4 & 4.7 \\
\hline Brazil & 14.8 & 13.8 & 12.3 & 4.7 * & 1.6 * & 2.8 * & 2.8 & 2.3 * & 1.6 & 1.8 * & 19.4 & 13.5 & 10.5 * & 7.1 & 6.0 * & 6.2 & 4.7 & 3.3 & 2.3 & 1.4 \\
\hline Bulgaria & 4.5 * & 8.7 * & 7.7 * & 9.1 * & $9.0 *$ & $3.8 *$ & 3.6 * & $3.5 *$ & 3.2 & $3.2 *$ & 8.3 * & 10.2 * & * 9.4 * & 8.8 & $7.6 *$ & 2.2 & 2.3 & 2.1 & 1.6 & 1.2 \\
\hline Burkina Faso & 26.0 & 21.1 & 26.6 & 25.9 & 20.7 & 20.5 * & 15.5 & 15.7 & 24.4 & 10.9 & 48.6 * & 40.7 & 45.5 & 42.4 & 32.9 & 20.2 & 20.0 & 18.6 & 15.9 & 9.8 \\
\hline Burundi & - & - & - & - & - & 7.2 * & 7.5 * & 8.2 & 9.0 & 6.1 & 58.1 * & 59.6 * & 63.1 & 57.7 & 57.5 & 17.1 & 17.0 & 14.9 & 11.9 & 8.3 \\
\hline Cambodia & 32.1 & 29.3 & 32.0 & 20.8 & 14.2 & 14.4 * & 13.4 & 16.9 & 8.3 & 9.6 & 60.0 * & 58.6 & 49.2 & 43.7 & 32.4 & 11.8 & 12.2 & 11.1 & 6.4 & 3.8 \\
\hline Cameroon & 37.8 & 38.0 & 32.3 & 23.1 & 9.9 & 4.5 & 7.1 * & 6.2 & 6.8 & 5.8 & 36.3 & 40.1 * & 38.2 & 35.9 & 32.6 & 13.6 & 15.1 & 15.1 & 12.6 & 9.5 \\
\hline Central Afric & 47.3 & 49.6 & 44.1 & 41.8 & 47.7 & 9.6 * & 8.3 & 10.5 & 12.2 & 7.4 & 42.2 * & 38.0 & 44.6 & 45.1 & 40.7 & 17.7 & 17.5 & 17.4 & 16.9 & 13.9 \\
\hline Chad & 59.1 & 51.5 & 40.1 & 39.7 & 34.4 & 16.2 * & 16.4 & 13.9 & 16.1 & 15.7 & 45.6 * & 45.0 & 39.3 & 44.8 & 38.7 & 21.5 & 20.3 & 19.1 & 17.8 & 14.8 \\
\hline Chile & 9.0 & 5.8 & 4.7 * & 4.0 * & 2.5 * & $0.5 *$ & 0.5 & 0.5 & 0.5 & 0.3 & $4.1 *$ & 3.9 & 2.9 & 2.3 & 1.8 & 1.9 & 1.3 & 1.1 & 0.9 & 0.8 \\
\hline China & 23.9 & 20.1 & 16.2 & 15.6 & 9.3 & 4.2 & 5.0 & 2.5 & 2.9 & 2.3 & 32.3 & 31.2 & 17.8 & 11.7 & 9.4 & 5.4 & 4.8 & 3.7 & 2.4 & 1.3 \\
\hline Colombia & 14.6 & 10.7 & 9.9 & 9.5 & 8.8 & 3.8 & 1.7 & 1.1 & 1.5 & 0.9 & 21.8 & 19.7 & 18.1 & 16.2 & 12.7 & 3.5 & 3.0 & 2.5 & 2.2 & 1.7 \\
\hline Comoros & - & - & - & - & - & 5.3 & 10.7 & 13.3 & 9.6 & 11.1 & 38.5 & 40.0 & 46.9 & 49.8 & 32.1 & 12.5 & 10.8 & 10.1 & 9.7 & 7.8 \\
\hline Congo, Dem & - & - & - & - & - & 10.8 * & 11.4 & 20.9 & 14.0 & 8.1 & 45.6 * & 51.0 & 44.4 & 45.8 & 42.6 & 17.6 & 17.6 & 17.6 & 15.6 & 11.9 \\
\hline Congo, Rep. & 43.2 & 45.0 & 35.9 & 30.2 & 30.5 & 7.9 * & 7.8 * & 7.7 * & 8.0 & 5.9 & 32.7 * & 32.9 * & * 30.9 * & 31.2 & 25.0 & 9.2 & 10.7 & 12.1 & 9.5 & 4.9 \\
\hline Costa Rica & 5.2 & 5.4 & 5.2 & 6.0 & $3.8 *$ & 2.1 * & 2.4 & 1.6 * & 1.5 * & $1.1 *$ & 10.5 * & 8.2 & 7.7 * & 6.1 * & 3.5 * & 1.7 & 1.5 & 1.3 & 1.0 & 1.0 \\
\hline Côte d'Ivoir & 0.7 & 11.6 & 14.9 & 14.8 & 13.3 & 10.3 * & 8.3 & 6.9 & 8.4 & 7.6 & 38.5 * & 34.2 & 31.5 & 40.1 & 29.6 & 15.2 & 15.2 & 14.6 & 12.9 & 10.0 \\
\hline Croatia & - & 15.1 * & 10.5 * & 2.7 * & $2.5 *$ & - & 1.7 & 1.2 * & 1.1 * & $1.2 *$ & - & 1.6 & 1.3 * & 1.0 * & 1.0 * & - & 1.0 & 0.8 & 0.7 & 0.5 \\
\hline Cuba & 5.7 & 20.7 & 5.6 & 1.6 * & $0.8 *$ & 4.0 * & 3.2 * & 2.4 & 2.7 & 2.1 * & 9.1 * & 8.7 * & 7.0 & 7.5 & $4.9 *$ & 1.3 & 1.1 & 0.8 & 0.7 & 0.6 \\
\hline Djibouti & 74.8 & 71.5 & 52.4 & 37.2 & 15.9 & 12.5 & 14.9 & 19.4 & 26.0 & 21.5 & 28.0 & 31.7 & 26.5 & 32.6 & 33.5 & 11.9 & 11.0 & 10.1 & 8.8 & 7.0 \\
\hline Dominican & 34.3 & 26.9 & 30.7 & 26.9 & 12.3 & 2.2 & 2.0 & 1.5 & 1.9 & 2.4 & 21.2 & 13.9 & 8.0 & 10.5 & 7.1 & 6.0 & 4.9 & 4.1 & 3.5 & 2.8 \\
\hline Ecuador & 19.4 & 14.7 & 17.8 & 19.3 & 10.9 & 3.3 * & 3.0 * & 3.2 & 2.3 & 2.3 & 35.5 * & 32.6 * & * 32.5 & 29.0 & 25.2 & 5.7 & 4.4 & 3.4 & 2.9 & 2.3 \\
\hline Egypt, Arab & 3.9 * & 3.2 * & 2.7 * & 3.8 * & $1.9 *$ & 4.5 & 5.7 & 6.9 & 5.3 & 9.5 & 34.9 & 34.9 & 24.6 & 23.8 & 22.3 & 8.5 & 6.4 & 4.5 & 3.1 & 2.2 \\
\hline EI Salvador & 16.2 & 15.6 & 12.5 & 10.2 & 12.4 & 2.2 & 1.4 & 1.5 & 1.3 & 2.0 & 36.7 & 29.5 & 32.3 & 24.6 & 14.0 & 6.0 & 4.5 & 3.2 & 2.4 & 1.6 \\
\hline Eritrea & - & - & - & - & - & - & 17.0 & 14.9 & 12.9 * & 15.3 & - & 47.8 & 43.7 & 49.6 * & 50.3 & - & 11.7 & 8.9 & 7.0 & 5.0 \\
\hline Estonia & - & 6.2 * & 4.2 * & 3.6 * & $2.0 *$ & - & 6.3 * & 4.2 * & 3.6 * & 2.4 * & - & 9.9 * & * 7.0 * & 5.9 * & 3.6 * & - & 1.6 & 1.1 & 0.7 & 0.3 \\
\hline Ethiopia & 74.8 & 71.4 & 57.9 & 45.9 & 32.0 & 9.2 & 12.6 * & 12.4 & 12.3 & 8.7 & 66.9 & 58.2 * & * 57.4 & 50.7 & 40.4 & 20.5 & 17.5 & 14.6 & 11.0 & 6.4 \\
\hline Fiji & 6.6 & 5.3 & 4.7 * & 4.3 * & $4.5 *$ & 9.7 * & 9.8 & 8.1 * & 6.3 & 6.6 * & 6.3 * & 4.3 & 5.9 * & 7.5 & 3.7 * & 3.0 & 2.6 & 2.4 & 2.3 & 2.4 \\
\hline Gabon & 1.7 & 9.5 & 4.3 * & 3.9 * & $2.7 *$ & 4.1 * & 4.0 * & 4.3 & 3.8 * & 3.4 & 30.1 * & 26.3 * & * 26.3 & 22.0 * & 17.5 & 9.3 & 8.8 & 8.5 & 7.6 & 5.6 \\
\hline Gambia, The & 13.3 & 17.3 & 14.1 & 15.0 & 5.3 & 11.3 * & 11.0 * & 8.9 & 7.4 & 11.5 & 35.4 * & 36.1 & 24.1 & 27.6 & 24.5 & 17.0 & 14.2 & 11.9 & 9.8 & 7.4 \\
\hline Georgia & - & 46.4 & 14.8 & 6.3 & 7.4 & - & 4.1 * & 3.1 & 3.0 & 2.4 * & - & 25.2 * & * 16.1 & 14.7 & 11.8 * & - & 4.4 & 3.6 & 2.5 & 1.3 \\
\hline Ghana & 47.3 & 24.2 & 17.5 & 11.6 & $2.3 *$ & 7.9 & 10.9 & 9.9 & 6.1 & 4.7 & 39.7 & 41.2 & 31.3 & 28.1 & 18.8 & 12.8 & 11.4 & 10.1 & 8.8 & 7.8 \\
\hline Guatemala & 14.9 & 15.5 & 22.1 & 16.2 & 15.6 & 3.6 * & 3.8 & 3.7 & 2.4 * & 2.1 * & 54.1 * & 55.4 & 50.0 & 50.1 * & 44.0 * & 8.1 & 6.3 & 5.1 & 4.1 & 3.1 \\
\hline Guinea & 23.2 & 23.9 & 27.2 & 23.1 & 16.4 & 10.2 * & 14.0 & 10.3 & 10.8 & 7.8 & 41.1 * & 35.3 & 46.9 & 39.3 & 33.5 & 23.8 & 20.6 & 17.0 & 13.7 & 10.1 \\
\hline Guinea-Bis & 23.1 & 21.3 & 28.4 & 25.4 & 20.7 & 8.5 * & 7.8 * & 11.8 & 8.9 & 6.0 & 43.3 * & 39.7 * & * 36.1 & 47.7 & 27.6 & 22.5 & 20.4 & 18.1 & 15.7 & 12.4 \\
\hline Guyana & 22.8 & 16.4 & 10.4 & 10.1 & 10.6 & 11.4 * & 13.3 & 12.1 & 8.3 & 6.4 & 15.8 * & 14.0 & 13.8 & 18.2 & 12.0 & 6.1 & 5.4 & 4.9 & 4.4 & 3.7 \\
\hline Haiti & 61.1 & 62.8 & 55.2 & 57.6 & 53.4 & 5.9 & 9.4 & 5.6 & 10.3 & 5.2 & 40.1 & 37.2 & 28.3 & 29.7 & 21.9 & 14.5 & 12.4 & 10.4 & 9.0 & 7.3 \\
\hline Honduras & 23.0 & 20.5 & 19.0 & 16.7 & 12.2 & 2.1 & 2.0 & 1.2 & 1.4 & 1.4 & 42.5 & 44.5 & 34.5 & 29.9 & 22.7 & 5.9 & 4.7 & 3.8 & 3.1 & 2.2 \\
\hline India & 23.7 & 21.6 & 17.0 & 21.2 & 15.2 & 20.3 & 19.1 & 17.1 & 20.0 & 15.0 & 62.7 & 51.8 & 54.2 & 47.9 & 38.8 & 12.6 & 10.9 & 9.1 & 7.5 & 5.3 \\
\hline Indonesia & 19.7 & 15.5 & 17.2 & 18.8 & 7.6 & 11.9 * & 14.9 & 5.5 & 14.4 & 13.5 & 50.3 * & 48.1 & 42.4 & 28.6 & 36.4 & 8.4 & 6.6 & 5.2 & 4.1 & 2.9 \\
\hline Iran, Islami & 5.1 & 4.5 * & 5.2 & 6.5 & $3.2 *$ & 8.3 * & 8.1 & 6.1 & 4.8 & 4.0 & 26.7 * & 24.4 & 20.4 & 7.1 & 6.8 & 5.7 & 4.5 & 3.5 & 2.6 & 1.7 \\
\hline Iraq & 7.9 & 21.0 & 24.6 & 25.1 & 22.8 & 4.4 & 6.7 * & 6.6 & 6.4 & 7.4 & 27.6 & 29.9 * & * 28.3 & 23.8 & 22.6 & 5.3 & 4.9 & 4.5 & 4.1 & 3.4 \\
\hline Jamaica & 10.4 & 8.4 & 7.8 & 6.8 & 8.1 & 4.9 & 4.5 & 3.0 & 3.9 & 3.5 & 10.8 & 9.5 & 6.6 & 5.1 & 4.8 & 3.0 & 2.6 & 2.4 & 2.1 & 1.7 \\
\hline Jordan & 5.5 & 8.3 & 7.0 & 1.9 * & 1.8 * & 3.8 & 2.4 & 2.5 & 2.1 * & 2.4 & 20.5 & 11.1 & 12.0 & 9.5 * & 7.8 & 3.7 & 3.2 & 2.8 & 2.4 & 1.9 \\
\hline Kazakhstan & - & 2.9 * & 4.4 * & 5.5 & $2.5 *$ & - & 6.4 & 2.5 & 4.9 & 4.1 & - & 23.3 & 13.9 & 17.5 & 13.1 & - & 5.3 & 4.4 & 3.3 & 1.6 \\
\hline Kenya & 32.4 & 35.3 & 32.3 & 31.8 & 21.2 & 5.5 & 9.4 & 7.4 & 7.7 & 4.0 & 37.0 & 39.8 & 41.0 & 40.9 & 26.0 & 9.9 & 11.1 & 11.1 & 9.8 & 7.1 \\
\hline Kuwait & 39.4 & 10.8 & 1.9 * & 1.5 * & $3.1 *$ & 5.0 * & 12.0 & 2.2 & 3.3 & 2.4 & 14.7 * & 14.9 & 4.0 & 4.5 & 5.8 & 1.7 & 1.4 & 1.3 & 1.2 & 1.0 \\
\hline Kyrgyz Republic & - & 15.7 & 15.2 & 10.4 & 6.0 & - & 5.7 & 3.9 * & 3.4 & 2.8 & - & 36.2 & 29.4 * & 18.1 & 12.9 & - & 6.1 & 4.9 & 4.0 & 2.4 \\
\hline Lao PDR & 42.8 & 44.0 & 39.2 & 29.5 & 18.5 & $11.3 *$ & 12.3 & 17.5 & 7.3 & 6.4 & $56.1 *$ & 52.9 & 48.2 & 47.6 & 43.8 & 16.2 & 14.0 & 11.7 & 9.7 & 7.1 \\
\hline Latvia & - & 2.2 * & 5.4 * & 1.9 * & 1.4 * & - & 4.9 * & $4.5 *$ & 3.6 * & $2.5 *$ & - & 7.6 * & 8.1 * & 5.8 * & $2.9 *$ & - & 2.4 & 1.7 & 1.3 & 0.8 \\
\hline Lebanon & 2.0 * & 2.0 * & 1.8 * & 3.5 * & $3.0 *$ & 5.5 * & 3.6 & $4.5 *$ & 6.6 & $3.5 *$ & 21.8 * & 17.2 & 16.2 * & 16.5 & $9.9 *$ & 3.2 & 2.6 & 2.0 & 1.4 & 0.9 \\
\hline Lesotho & 15.6 & 16.0 & 13.0 & 11.0 & 11.2 & 3.2 & 7.3 * & 6.7 & 5.6 & 2.8 & 39.2 & 37.5 & 53.0 & 45.2 & 33.2 & 8.6 & 9.3 & 11.5 & 12.3 & 9.8 \\
\hline Liberia & 29.0 & 38.4 & 36.5 & 39.7 & 31.9 & $8.4 *$ & 8.8 * & 7.4 & 7.8 & 5.6 & $59.0 *$ & 52.4 * & * 45.3 & 39.4 & 32.1 & 24.8 & 22.9 & 17.5 & 11.8 & 7.1 \\
\hline
\end{tabular}




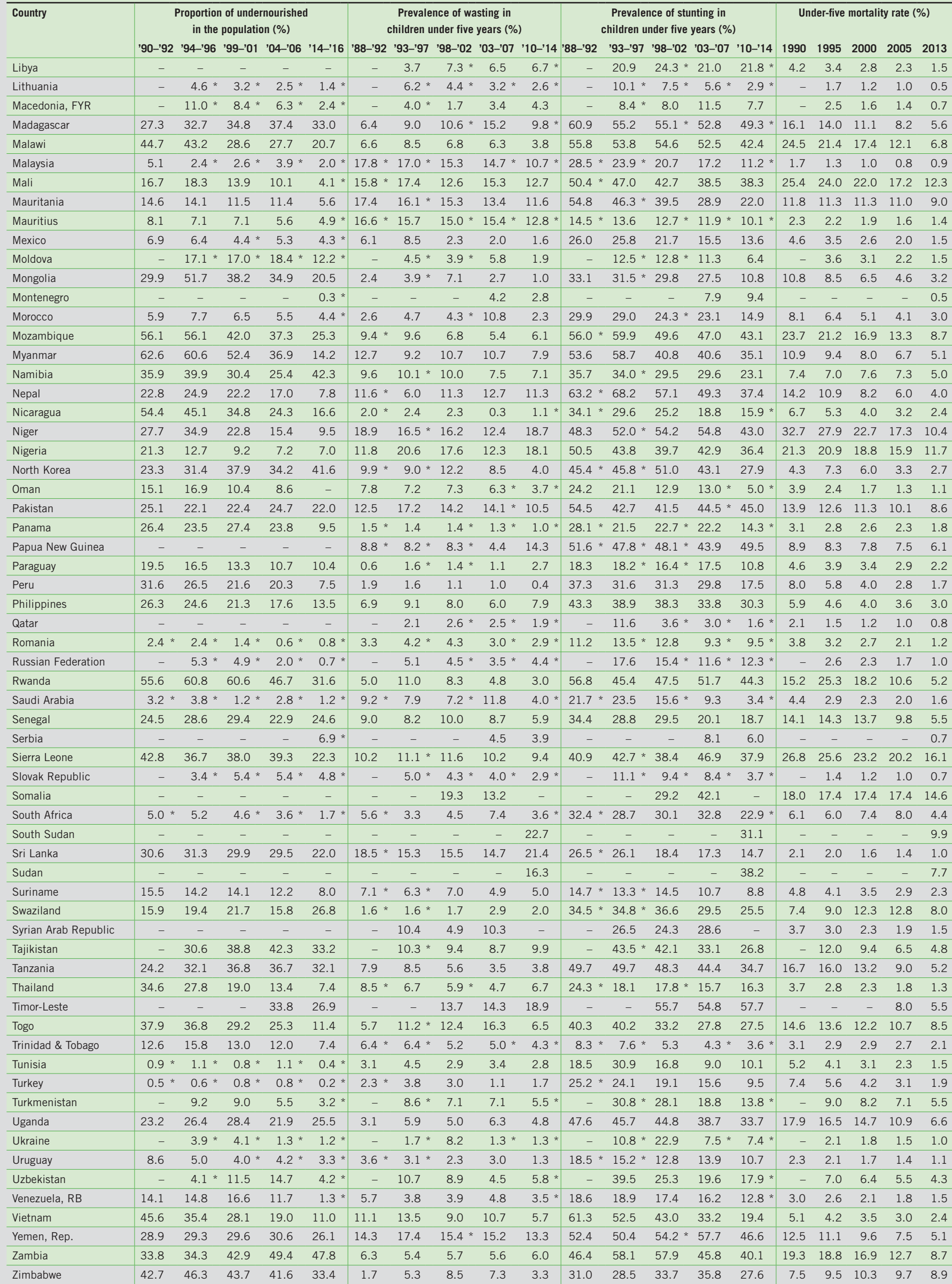

Note: Undernourishment data for 2014-2016 are provisional estimates.

- = Data not available or not presented. Some countries, such as the post-Soviet states prior to

* IFPRI estimates.

1991 , did not exist in the present borders in the given year or reference period. 
2015 GLOBAL HUNGER INDEX SCORES

\begin{tabular}{|c|c|c|c|c|c|c|c|c|c|c|c|}
\hline \multirow{2}{*}{$\begin{array}{l}\text { Country } \\
\text { with data from }\end{array}$} & 1990 & 1995 & 2000 & 2005 & 2015 & \multirow[b]{2}{*}{ with data from } & \multirow{2}{*}{$\begin{array}{c}1990 \\
\text { '88-'92 }\end{array}$} & \multirow{2}{*}{$\begin{array}{c}1995 \\
\text { '93-'97 }\end{array}$} & \multirow{2}{*}{$\begin{array}{c}2000 \\
\text { '98-'02 }\end{array}$} & \multirow{2}{*}{$\begin{array}{c}2005 \\
\text { '03-'07 }\end{array}$} & \multirow{2}{*}{$\begin{array}{c}2015 \\
\text { '10-'16 }\end{array}$} \\
\hline & '88-'92 & '93-'97 & '98-'02 & '03-'07 & '10-'16 & & & & & & \\
\hline & 47.4 & 55.9 & 52.5 & 44.9 & 35.4 & Liberia & 54.4 & 55.2 & 46.8 & 41.5 & 30.8 \\
\hline Albania & 21.4 & 19.1 & 21.1 & 17.1 & 13.2 & Libya & - & - & - & - & - \\
\hline Angola & 67.3 & 66.8 & 58.3 & 45.3 & 32.6 & Macedonia, FYR & - & 11.2 & 7.9 & 8.6 & 5.9 \\
\hline Argentina & 7.7 & 7.2 & 5.3 & 5.0 & $<5$ & Madagascar & 44.8 & 45.1 & 44.1 & 44.4 & 36.3 \\
\hline Armenia & - & 21.8 & 17.4 & 14.1 & 11.2 & Malawi & 58.9 & 55.9 & 45.3 & 39.1 & 27.3 \\
\hline Bahrain & - & - & - & - & - & Mali & 51.9 & 51.3 & 43.9 & 38.3 & 29.6 \\
\hline Bangladesh & 52.2 & 50.3 & 38.5 & 31.0 & 27.3 & Mauritania & 40.0 & 36.6 & 33.5 & 29.6 & 22.6 \\
\hline Belarus & - & $<5$ & $<5$ & $<5$ & $<5$ & Mauritius & 18.2 & 17.0 & 16.1 & 15.2 & 12.9 \\
\hline Benin & 46.1 & 42.6 & 38.2 & 33.3 & 21.8 & Mexico & 16.8 & 16.9 & 10.8 & 8.9 & 7.3 \\
\hline Bhutan & - & - & - & - & - & Moldova & - & 16.0 & 15.3 & 15.7 & 9.1 \\
\hline Bolivia & 38.9 & 35.1 & 30.5 & 27.2 & 16.9 & Mongolia & 32.0 & 39.3 & 33.1 & 27.0 & 14.7 \\
\hline Bosnia \& Herzegovina & - & 10.8 & 9.6 & 6.8 & $<5$ & Montenegro & - & - & - & - & $<5$ \\
\hline Brazil & 18.2 & 15.0 & 12.0 & 6.7 & $<5$ & Mozambique & 64.5 & 63.2 & 49.2 & 42.4 & 32.5 \\
\hline Bulgaria & 8.1 & 10.2 & 9.4 & 9.2 & 8.5 & Myanmar & 56.3 & 53.3 & 45.1 & 37.4 & 23.5 \\
\hline Burkina Faso & 53.0 & 46.1 & 48.4 & 49.6 & 31.8 & Namibia & 35.8 & 37.0 & 32.5 & 28.8 & 31.8 \\
\hline Burundi & - & - & - & - & - & Nepal & 44.5 & 40.3 & 36.9 & 31.6 & 22.2 \\
\hline Cambodia & 46.9 & 45.2 & 45.0 & 29.8 & 22.6 & Nicaragua & 38.3 & 32.2 & 25.6 & 17.8 & 13.6 \\
\hline Cameroon & 39.8 & 43.7 & 40.4 & 34.0 & 24.2 & Niger & 64.7 & 62.7 & 53.0 & 42.8 & 34.5 \\
\hline Central African Republic & 51.9 & 51.0 & 51.4 & 51.0 & 46.9 & Nigeria & 47.7 & 47.1 & 41.0 & 35.2 & 32.8 \\
\hline Chad & 65.0 & 60.6 & 52.0 & 53.1 & 46.4 & North Korea & 30.1 & 35.9 & 40.4 & 32.4 & 28.8 \\
\hline Chile & 6.8 & $<5$ & $<5$ & $<5$ & $<5$ & Oman & 20.1 & 18.4 & 13.1 & 11.4 & - \\
\hline China & 25.1 & 23.2 & 15.9 & 13.2 & 8.6 & Pakistan & 43.6 & 40.9 & 37.9 & 38.3 & 33.9 \\
\hline Colombia & 16.7 & 13.0 & 11.4 & 10.7 & 8.8 & Panama & 21.5 & 18.4 & 20.1 & 18.1 & 9.6 \\
\hline Comoros & - & - & - & - & - & Papua New Guinea & - & - & - & - & - \\
\hline Congo, Dem. Rep. & - & - & - & - & - & Paraguay & 17.2 & 15.8 & 13.5 & 12.0 & 10.5 \\
\hline Congo, Rep. & 38.9 & 41.1 & 38.1 & 33.5 & 26.6 & Peru & 30.7 & 25.0 & 20.9 & 18.8 & 9.1 \\
\hline Costa Rica & 7.5 & 7.0 & 6.1 & 5.7 & $<5$ & Philippines & 30.7 & 28.9 & 26.2 & 22.1 & 20.1 \\
\hline Djibouti & 56.1 & 56.1 & 48.5 & 46.1 & 33.2 & Rwanda & 53.9 & 66.3 & 58.5 & 44.5 & 30.3 \\
\hline Dominican Republic & 26.3 & 20.3 & 19.4 & 18.1 & 10.8 & Saudi Arabia & 15.8 & 14.3 & 10.4 & 11.8 & 5.1 \\
\hline Ecuador & 23.8 & 19.7 & 20.2 & 19.0 & 14.0 & Senegal & 36.8 & 36.9 & 37.9 & 28.5 & 23.2 \\
\hline Egypt, Arab Rep. & 20.5 & 18.9 & 15.1 & 13.1 & 13.5 & Serbia & - & - & - & - & 7.1 \\
\hline El Salvador & 22.4 & 18.6 & 16.8 & 13.1 & 11.1 & Sierra Leone & 58.8 & 56.0 & 53.5 & 52.4 & 38.9 \\
\hline Eritrea & - & - & - & - & - & Slovak Republic & - & 8.2 & 8.0 & 7.4 & 5.2 \\
\hline Estonia & - & 10.0 & 6.8 & 5.6 & $<5$ & Somalia & - & - & - & - & - \\
\hline Ethiopia & 71.7 & 67.3 & 58.6 & 48.5 & 33.9 & South Africa & 18.7 & 16.5 & 18.6 & 21.0 & 12.4 \\
\hline Fiji & 12.5 & 11.2 & 10.1 & 9.3 & 8.7 & South Sudan & - & - & - & - & - \\
\hline Gabon & 23.2 & 20.8 & 18.5 & 16.2 & 12.5 & Sri Lanka & 31.3 & 29.7 & 27.0 & 25.9 & 25.5 \\
\hline Gambia, The & 36.4 & 35.4 & 27.9 & 26.3 & 21.5 & Sudan & - & - & - & - & - \\
\hline Georgia & - & 31.8 & 15.2 & 10.2 & 8.5 & Suriname & 18.5 & 16.5 & 16.5 & 13.1 & 10.4 \\
\hline Ghana & 45.7 & 36.8 & 29.9 & 23.3 & 15.5 & Swaziland & 22.8 & 25.8 & 30.4 & 27.4 & 26.0 \\
\hline Guatemala & 28.8 & 27.8 & 28.0 & 23.9 & 21.1 & Syrian Arab Republic & - & - & - & - & - \\
\hline Guinea & 47.8 & 45.8 & 44.4 & 38.0 & 28.8 & Tajikistan & - & 40.3 & 40.4 & 36.5 & 30.3 \\
\hline Guinea-Bissau & 46.1 & 42.1 & 44.2 & 41.8 & 30.3 & Tanzania & 42.2 & 45.2 & 42.5 & 36.4 & 28.7 \\
\hline Guyana & 25.4 & 22.7 & 19.0 & 17.3 & 14.4 & Thailand & 28.4 & 22.3 & 17.6 & 13.6 & 11.9 \\
\hline Haiti & 52.1 & 52.1 & 42.8 & 45.4 & 37.3 & Timor-Leste & - & - & - & 42.7 & 40.7 \\
\hline Honduras & 26.5 & 24.7 & 20.4 & 17.8 & 13.4 & Togo & 42.5 & 44.1 & 38.6 & 36.4 & 23.0 \\
\hline India & 48.1 & 42.3 & 38.2 & 38.5 & 29.0 & Trinidad \& Tobago & 13.7 & 14.7 & 12.3 & 11.4 & 8.3 \\
\hline Indonesia & 34.8 & 32.5 & 25.3 & 26.5 & 22.1 & Tunisia & 11.5 & 14.2 & 8.9 & 6.7 & 5.6 \\
\hline Iran, Islamic Rep. & 18.5 & 16.5 & 13.7 & 9.5 & 6.8 & Turkey & 14.5 & 13.4 & 10.5 & 7.6 & 5.1 \\
\hline Iraq & 17.4 & 24.3 & 24.9 & 23.6 & 22.2 & Turkmenistan & - & 24.5 & 22.2 & 17.5 & 12.9 \\
\hline Jamaica & 12.5 & 10.7 & 8.8 & 8.2 & 8.1 & Uganda & 39.8 & 40.9 & 39.3 & 32.2 & 27.6 \\
\hline Jordan & 12.8 & 10.5 & 9.8 & 6.5 & 5.8 & Ukraine & - & 7.1 & 13.4 & $<5$ & $<5$ \\
\hline Kazakhstan & - & 15.4 & 10.7 & 12.3 & 8.0 & Uruguay & 12.2 & 9.4 & 7.6 & 8.1 & 5.7 \\
\hline Kenya & 34.8 & 40.0 & 37.9 & 36.6 & 24.0 & Uzbekistan & - & 23.7 & 21.9 & 18.5 & 13.3 \\
\hline Kuwait & 24.3 & 16.0 & $<5$ & $<5$ & 5.0 & Venezuela, RB & 16.3 & 15.3 & 15.2 & 13.1 & 7.0 \\
\hline Kyrgyz Republic & - & 24.1 & 20.2 & 14.3 & 9.4 & Vietnam & 44.6 & 38.8 & 30.3 & 24.6 & 14.7 \\
\hline Lao PDR & 52.9 & 51.1 & 48.7 & 36.9 & 28.5 & Yemen, Rep. & 44.4 & 44.4 & 42.9 & 42.1 & 34.2 \\
\hline
\end{tabular}




\section{NEAR EAST AND NORTH AFRICA}

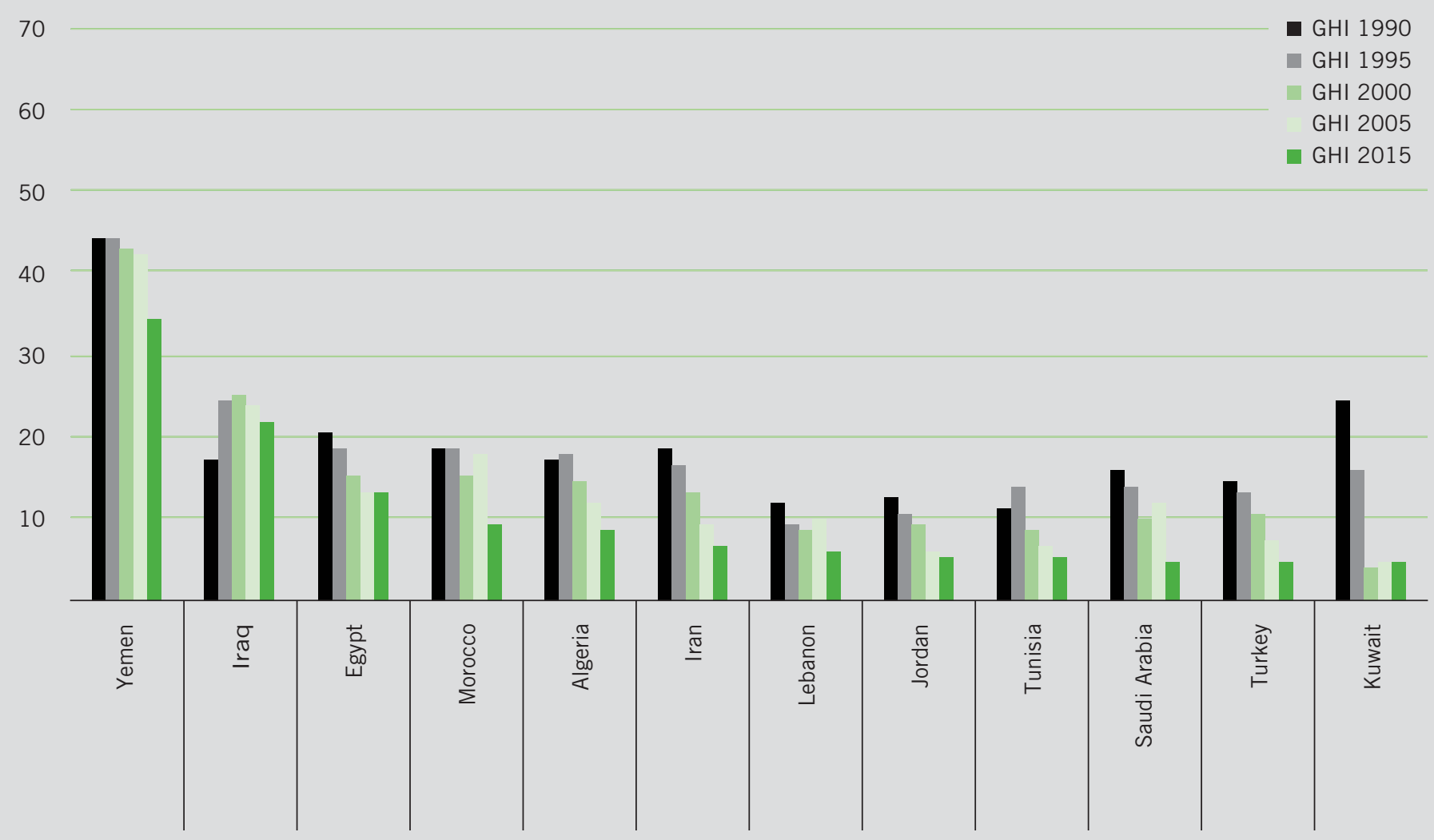

\footnotetext{
WEST AFRICA
}

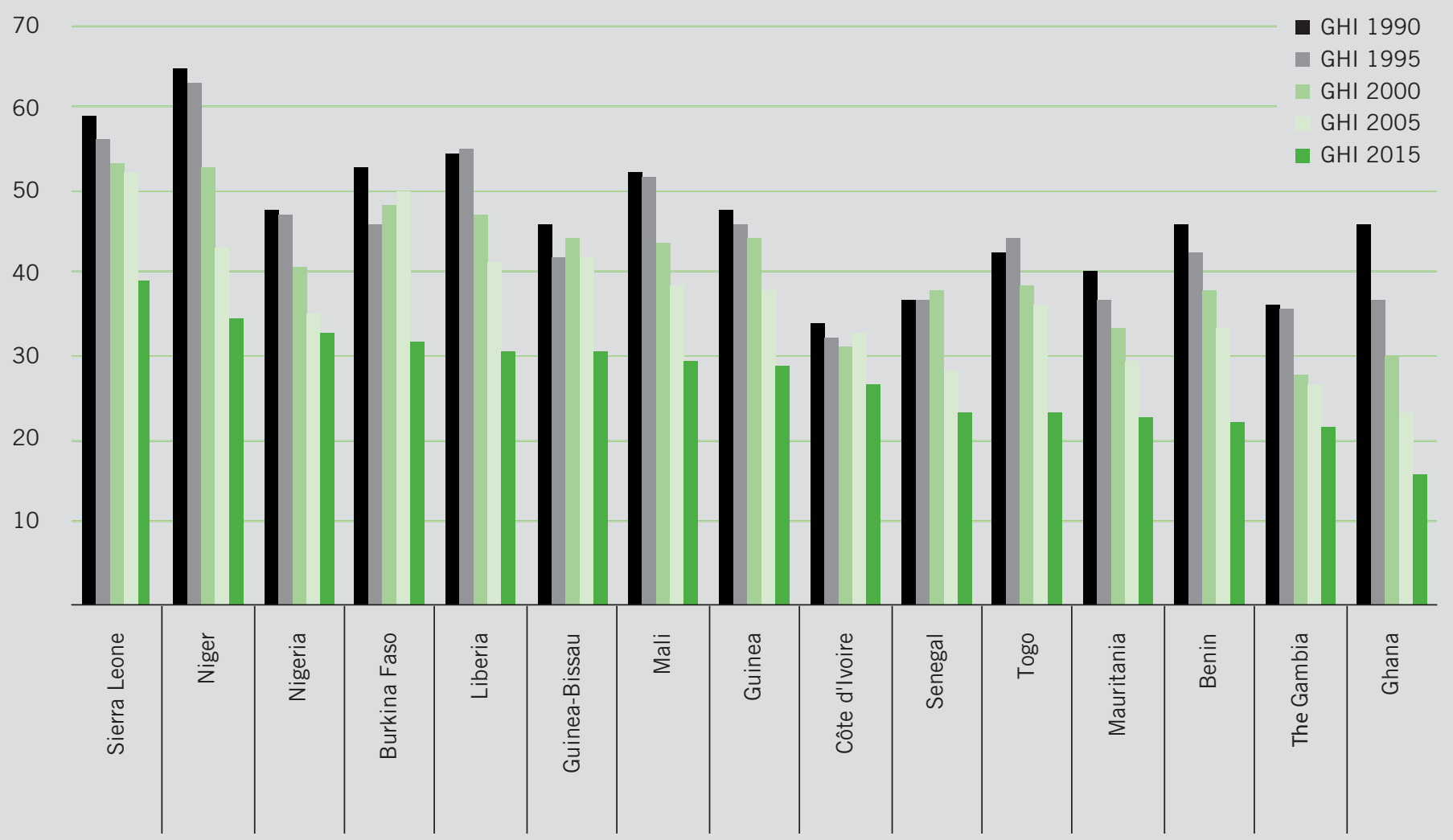




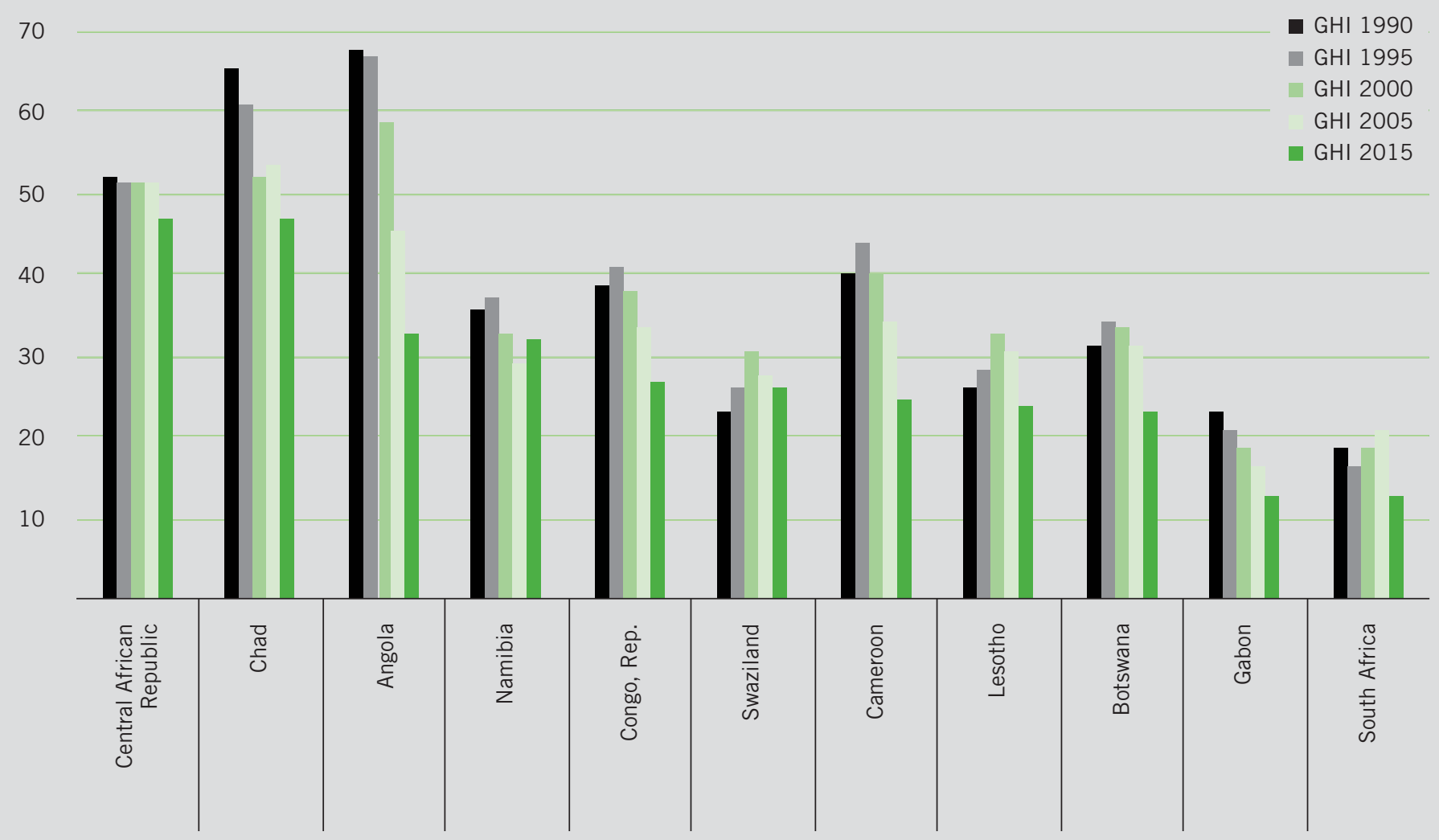

EAST AFRICA

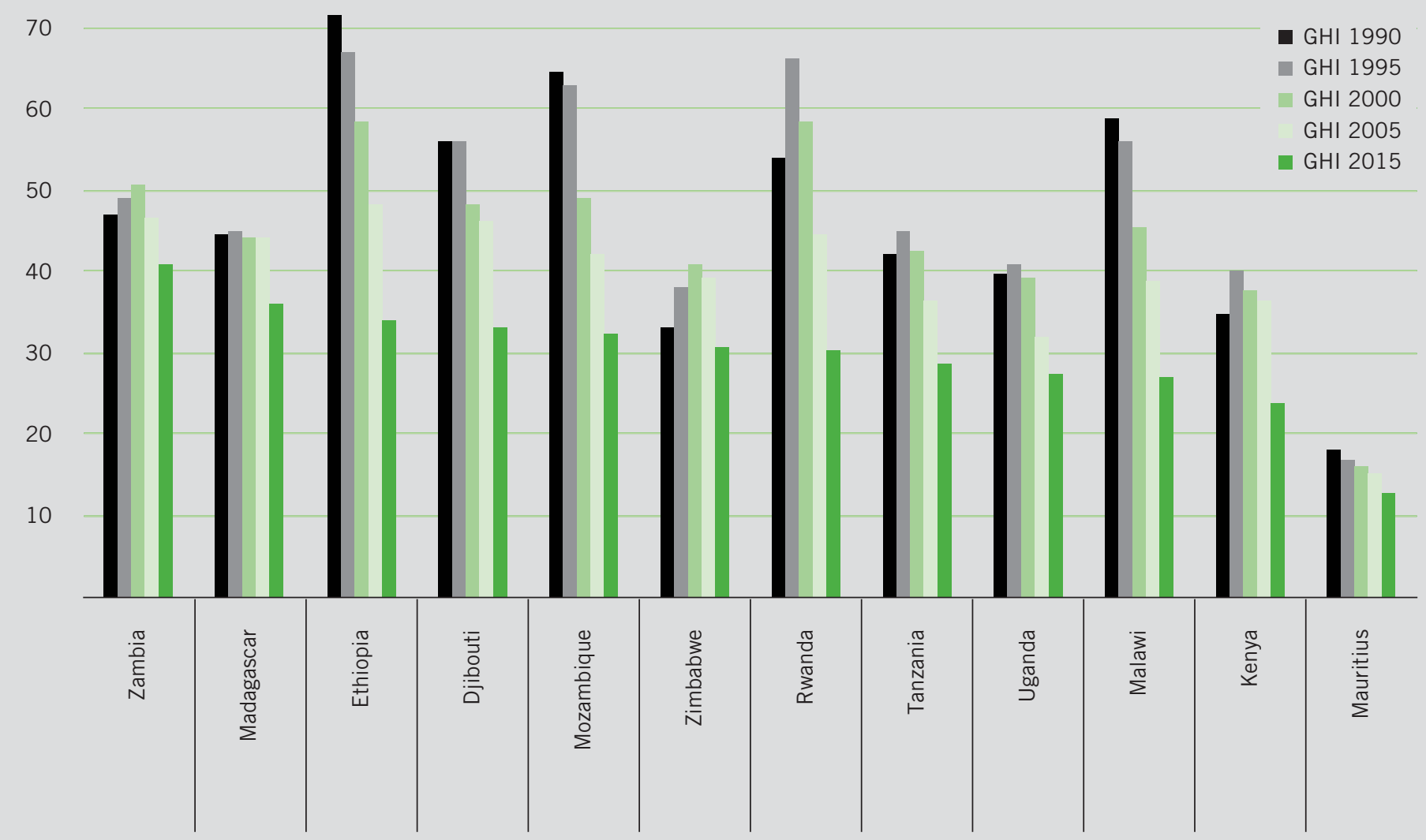


SOUTH AMERICA

70

- GHI 1990

GHI 1995

- GHI 2000

60

GHI 2005

- GHI 2015

50

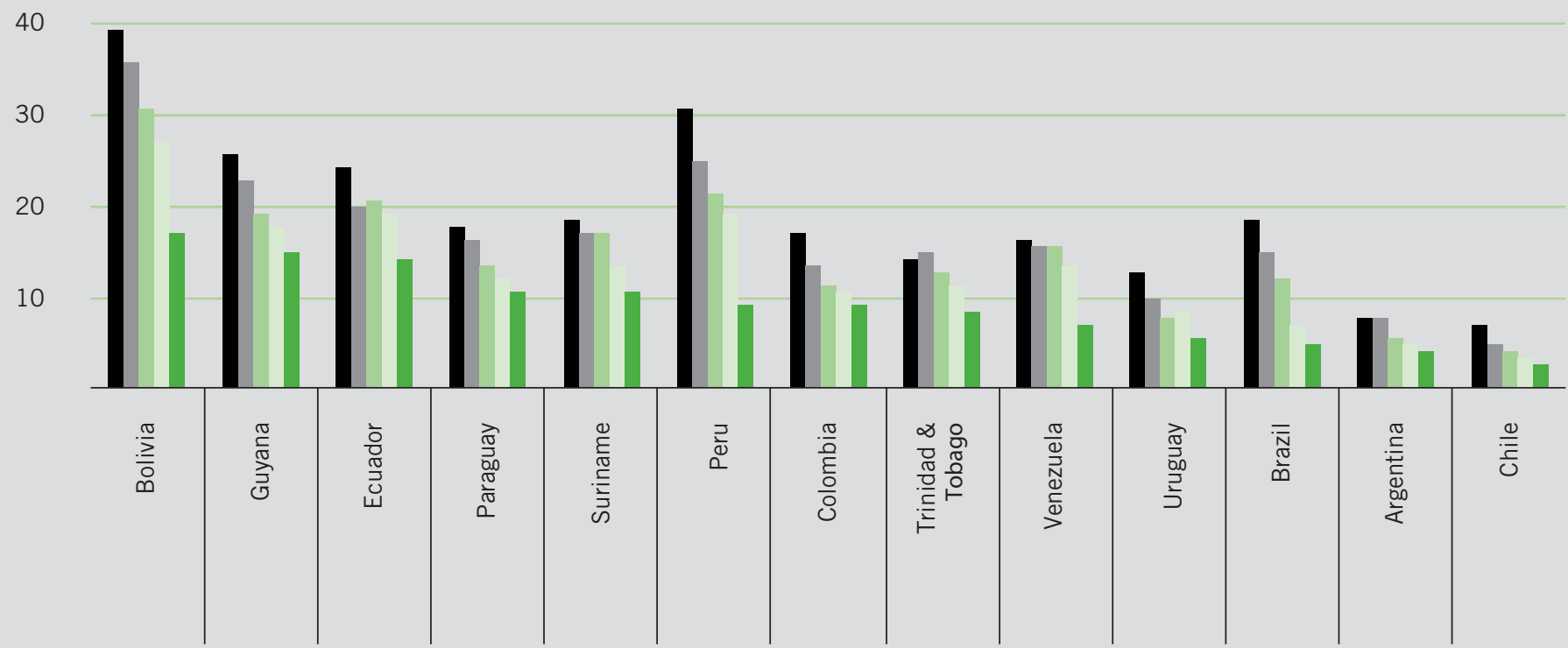

\section{CENTRAL AMERICA AND THE CARIBBEAN}

70

- GHI 1990

GHI 1995

GHI 2000

GHI 2005

60

- GHI 2015

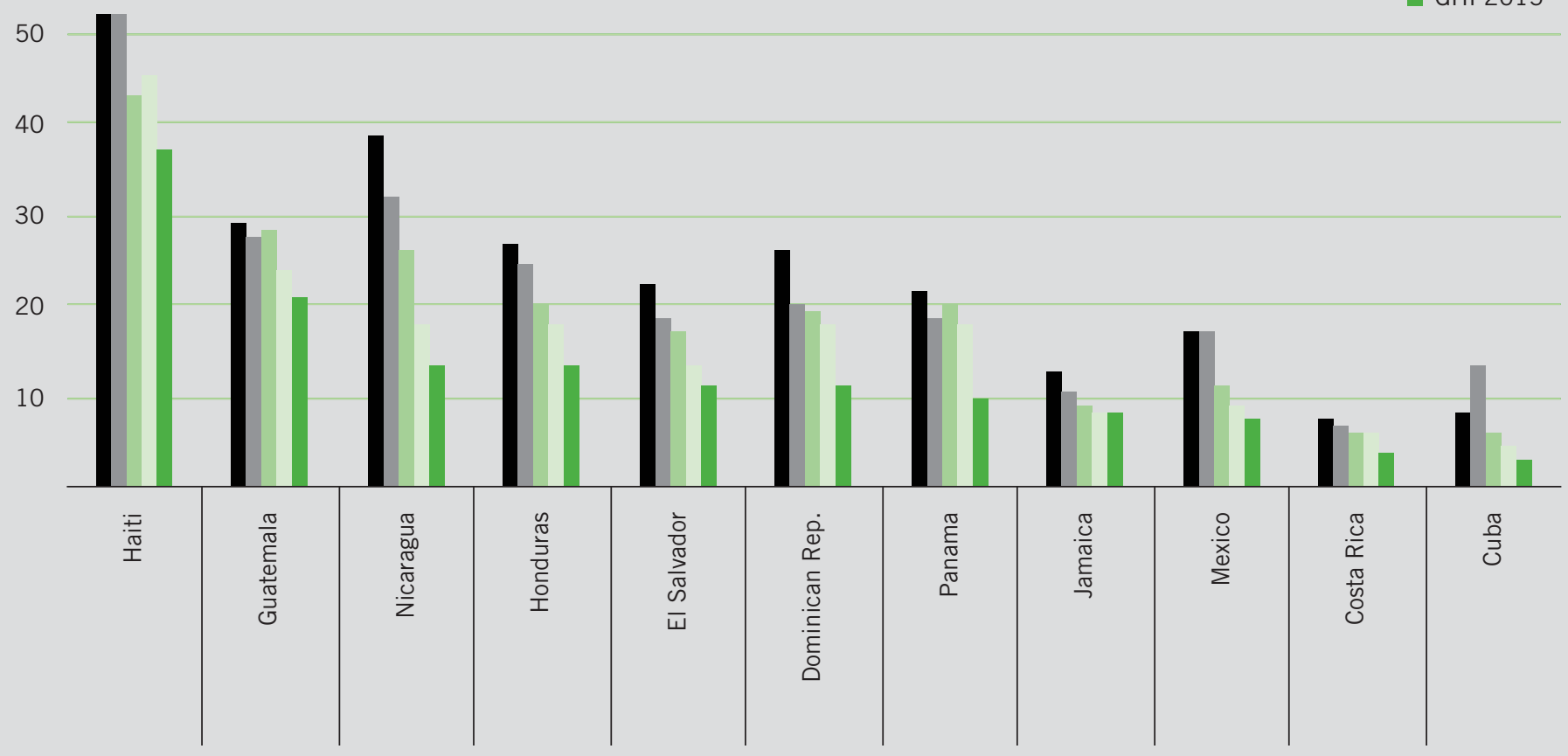




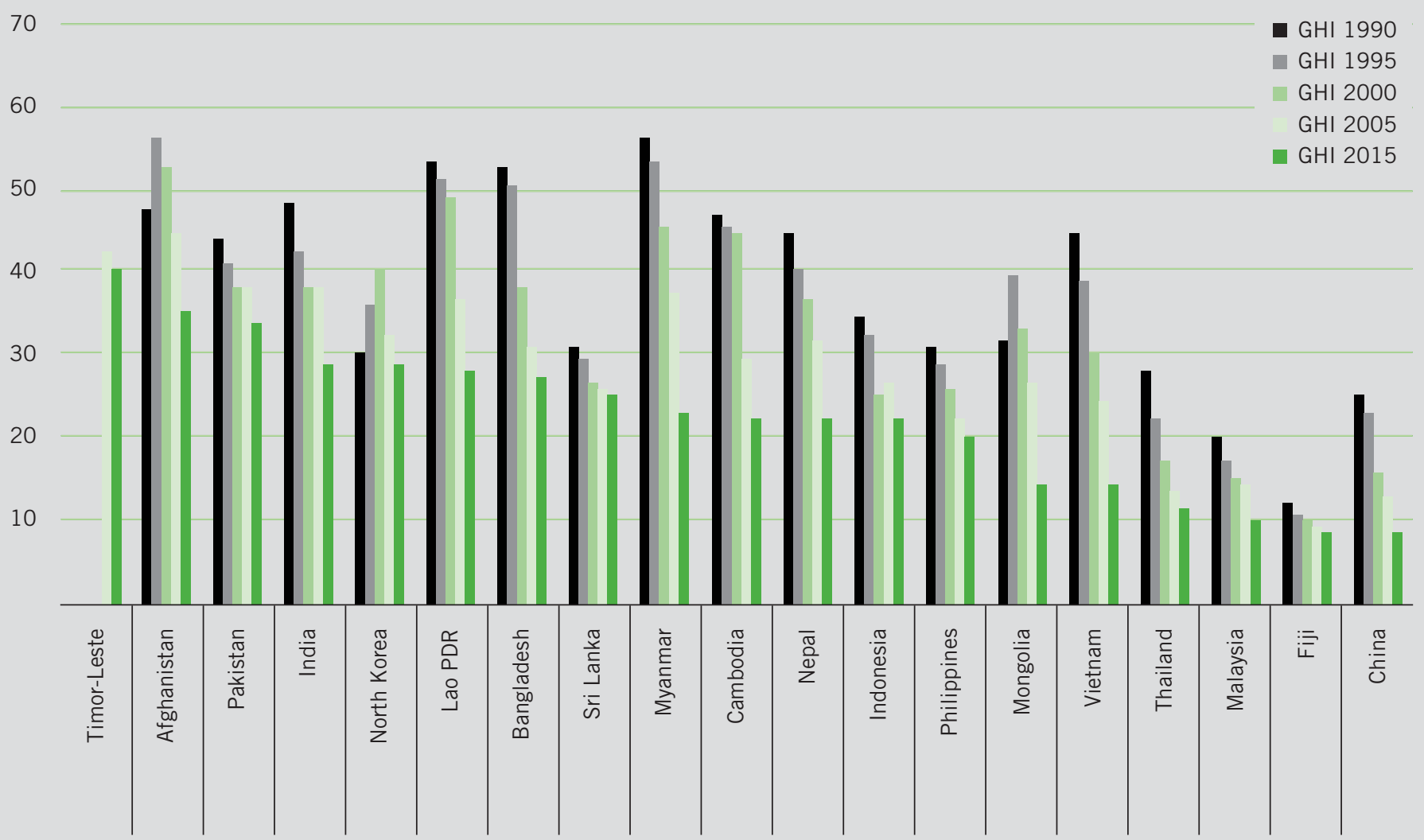

\section{EASTERN EUROPE AND THE COMMONWEALTH OF INDEPENDENT STATES}

70

- GHI 1990

GHI 1995

- GHI 2000

60

GHI 2005

- GHI 2015

50

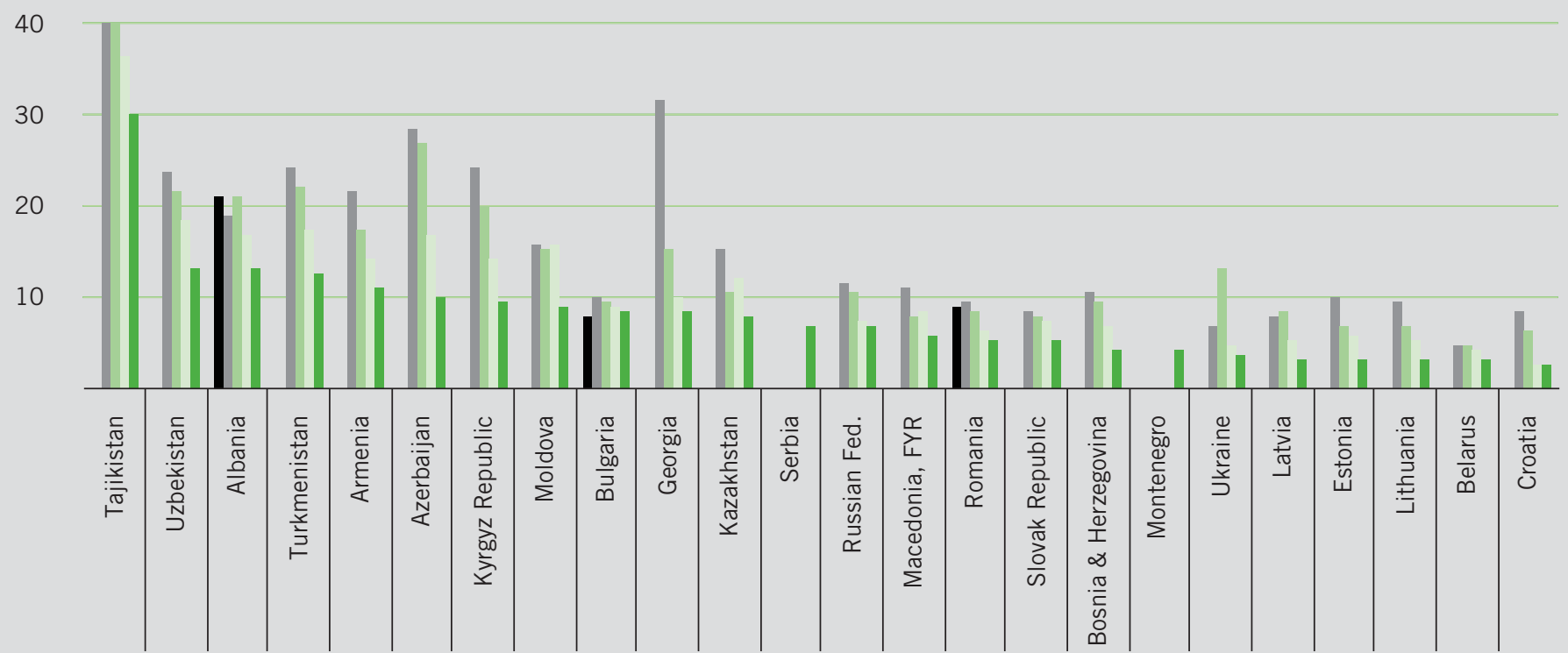




\section{A}

Acosta, A. M., and L. Haddad. 2014. "The Politics of Success in the Fight against Malnutrition in Peru." Food Policy 44: 26-35.

Africa Watch. 1991. "Evil Days: 30 Years of War and Famine in Ethiopia." Accessed July 10, 2015. http://bit.ly/1L7IPp2.

Alkire, S., and M. E. Santos. 2010. Multidimensional Poverty Index: 2010 Data. Oxford: Oxford Poverty and Human Development Initiative, University of Oxford. www.ophi.org.uk/policy /multidimensional-poverty-index/.

Alnasrawi, A. 2000. "Iraq: Economic Embargo and Predatory Rule." In War, Hunger and Displacement: The Origins of Humanitarian Emergencies, Volume 2: Case Studies, edited by E. W. Nafziger, F. Stewart, and R. Väyrynen, 89-118. Oxford: Oxford University Press.

Apps, P. 2015. "Breaking a Decades'-Long Trend, the World Gets More Violent." Reuters March 20. http://reut.rs/1GyA1DD.

Arieff, A. 2014. Crisis in the Central African Republic. Washington, DC: Congressional Research Service. January 27. http://fpc.state.gov/documents/organization/221774.pdf.

Article 19. 1990. Starving in Silence: A Report on Famine and Censorship. London: Article 19 www.article19.org/data/files/medialibrary/3/censorship-famine-and-censorship.pdf.

AVERT. 2014. Impact of HIV and AIDS in Sub-Saharan Africa. Accessed July 15, 2015. www .avert.org/impact-hiv-and-aids-sub-saharan-africa.htm.

Avula, R., S. Kadiyala, K. Singh, and P. Menon. 2013. The Operational Evidence Base for Delivering Direct Nutrition Interventions in India: A Desk Review. IFPRI Discussion Paper 1299. Washington, DC: International Food Policy Research Institute.

\section{B}

Becker, J. 1996. Hungry Ghosts: Mao's Secret Famine. New York: Owl Books.

Black, R. E., C. G. Victora, S. P. Walker, Z. A. Bhutta, P. Christian, M. de Onis, M. Ezzati, S. Grantham-McGregor, J. Katz, R. Martorell, and R. Uauy. 2013. "Maternal and Child Undernutrition and Overweight in Low-Income and Middle-Income Countries." The Lancet 832 (9890): 427-451.

Boos, A., and K. Holm-Müller. 2015. "The Zambian Resource Curse and its Influence on Genuine Savings as an Indicator for 'Weak' Sustainable Development." Environment, Development and Sustainability. http://bit.ly/1gv0R8y.

Bredenkamp, C., L. R. Buisman, and E. Van de Poel. 2014. "Persistent Inequalities in Child Undernutrition: Evidence from 80 Countries, from 1990 to Today." International Journal of Epidemiology 43 (4): 1328-1335.

Brinkman, H.-J., and C. S. Hendrix. 2011. Food Insecurity and Violent Conflict: Causes, Consequences, and Addressing the Challenges. Occasional Paper 24. Rome: World Food Programme.

Buhaug, H., J. Nordkvelle, T. Bernauer, T. Böhmelt, M. Brzoska, J. W. Busby et al. 2014 "One Effect to Rule Them All? A Comment on Climate and Conflict." Climatic Change 127 (3-4): 391-397.

\section{C}

Collier, P., and A. Hoeffler. 2004. "Greed and Grievance in Civil War." Oxford Economic Papers 56: 563-595. http://oep.oxfordjournals.org/content/56/4/563.full.pdf+html.

Conquest, R. 1987. The Harvest of Sorrow: Soviet Collectivization and the Terror Famine. Oxford: Oxford University Press.
Cook, J. 2012. "Israel's Starvation Diet for Gaza." The Electronic Intifada, October 24. http:// electronicintifada.net/content/israels-starvation-diet-gaza/11810.

Cotula, L. 2013. The Great African Land Grab: Agricultural Investments and the Global Food System. London: Zed Books.

CRED (Centre for Research on the Epidemiology of Disasters). 2013. People Affected by Conflict 2013: Humanitarian Needs in Numbers. Louvain, Belgium.

\section{D}

Davis, M. 2002. Late Victorian Holocausts: El Niño Famines and the Making of the Third World. London: Verso.

de Châtel, F. 2014. "The Role of Drought and Climate Change in the Syrian Uprising: Untangling the Triggers of the Revolution." Middle Eastern Studies 50 (4): 521-535.

de Waal, A. 1997. Famine Crimes: Politics and the Disaster Relief Industry in Africa. London: James Currey.

Devereux, S. 2000. Famine in the Twentieth Century. IDS (Institute of Development Studies) Working Paper 105. www.ids.ac.uk/publication/famine-in-the-twentieth-century.

2007. “Introduction: From ‘Old Famines' to 'New Famines."' In The New Famines: Why Famines Persist in an Era of Globalization, edited by S. Devereux, 1-26. London: Routledge.

Drèze, J. 1991. "Famine Prevention in India." In The Political Economy of Hunger: Vol. II: Famine Prevention, edited by J. Drèze and A. Sen. Oxford: Clarendon Press.

Dyson, T., and C. Ó Gráda. 2002. Famine Demography: Perspectives from the Past and Present. Oxford: Oxford University Press.

$\mathbf{E}$

Economist. 2015. "Of Secrecy and Stunting." Accessed July 13, 2015. http://econ.st/1GV7vKE.

\section{$\mathbf{F}$}

FAO (Food and Agriculture Organization of the United Nations). 2015. Food Security Indicators (Updated May 27, 2015). Accessed May 27, 2015. http://faostat3.fao.org/download/D/*/E.

FAO, IFAD (International Fund for Agricultural Development), and WFP (World Food Programme). 2011. The State of Food Insecurity in the World 2011: How Does International Price Volatility Affect Domestic Economies and Food Security? Rome: FAO. http://bit.ly/XTilNx.

FAO, IFAD, and WFP. 2015. The State of Food Insecurity in the World 2015. Meeting the 2015 International Hunger Targets: Taking Stock of Uneven Progress. Rome: FAO. http://bit .ly/1PNrNA4.

\section{G}

Geneva Declaration. 2011. Global Burden of Armed Violence 2011: Lethal Encounters. Cambridge: Cambridge University Press.

Gillespie, S., L. Haddad, V. Mannar, P. Menon, N. Nisbett, and Maternal and Child Nutrition Study Group. 2013. "The Politics of Reducing Malnutrition: Building Commitment and Accelerating Progress." The Lancet 382 (9891): 552-569.

Goodkind, D., L. West, and P. Johnson. 2011. "A Reassessment of Mortality in North Korea, 1993-2008." Paper presented at the annual meeting of the Population Association of America, Washington, DC, March 31-April 2. http://bit.ly/1QLmDCJ.

Grove, R. 1998. "Global Impact of the 1789-93 El Niño." Nature 393: 318-319. 
Guha-Sapir, D., P. Hoyois, and R. Below. 2014. Annual Disaster Statistical Review 2013: The Numbers and Trends. Louvain: Centre for Research in the Epidemiology of Disasters.

Guha-Sapir, D., and F. Vogt. 2009. "Cyclone Nargis in Myanmar: Lessons for Public Health Preparedness for Cyclones." American Journal of Disaster Medicine 4 (5): 273-278.

\section{H}

Harris, K., D. Keen, and T. Mitchell. 2013. When Disasters and Conflicts Collide: Improving Links Between Disaster Resilience and Conflict Prevention. London: Overseas Development Institute.

Hobsbawm, E. 1989. The Age of Empire: 1875-1914. London: Vintage.

1996. The Age of Extremes: A History of the World, 1914-1991. London: Vintage.

Hossain, M. 2010. From Protest to Freedom: The Birth of Bangladesh. Dhaka: Mofidul Hoque

Howe, P., and S. Devereux. 2004. "Famine Intensity and Magnitude Scales: A Proposal for an Instrumental Definition of Famine." Disasters 28 (4): 353-372.

Human Security Report Project. 2013. Human Security Report 2013: The Decline in Globa Violence: Evidence, Explanation, and Contestation. Vancouver: Human Security Press. http:// bit.ly/1ljcEkL.

Humphreys, M., J. Sachs, and J. E. Stiglitz, eds. 2007. Escaping the Resource Curse. New York: Columbia University Press.

IDMC (Internal Displacement Monitoring Centre). 2014. Chad: Regional Instability Overshadows the Fate of Remaining IDPs. Accessed July 9, 2015. http://bit.ly/leRZOOW.

IFPRI (International Food Policy Research Institute)/Welthungerhilfe/Concern. 2007. The Challenge of Hunger 2007: Global Hunger Index: Facts, Determinants, and Trends. Washington, DC, Bonn, and Dublin.

IGME (Inter-agency Group for Child Mortality Estimation). 2014. Child Mortality Estimates Info, Under-five Mortality Estimates. (Updated September 16, 2014). Accessed May 18, 2015. www.childmortality.org.

IIPS (International Institute for Population Sciences) and Macro International. 2007. National Family Health Survey (NFHS-3), 2005-6: India: Volume I. Demographic and Health Surveys. Mumbai, India: IIPS.

India, Ministry of Women and Child Development, and UNICEF, India. 2014. Rapid Survey on Children (2013-14). Delhi: UNICEF.

International Crisis Group. 2010. War Crimes in Sri Lanka. ICG Asia Report 191.

International Rescue Committee. 2008. Mortality in the Democratic Republic of Congo: An Ongoing Crisis. New York.

Islam, S., and L. E. Susskind. 2013. Water Diplomacy: A Negotiated Approach to Managing Complex Water Networks. New York: Resources for the Future Press.

\section{K}

Kaldor, M. 1999. New and Old Wars: Organized Violence in a Global Era. Cambridge: Polity.

Kaldor, M., T. L. Karl, and Y. Said. 2007. "Introduction." In Oil Wars, edited by M. Kaldor, T. L. Karl, and Y. Said, 1-40. London: Pluto Press.

Keen, D. 2008. Complex Emergencies. London: Polity.
Kelley, C., S. Mohtadi, M. Cane, R. Seager, and Y. Kushnir. 2015. "Climate Change in the Fertile Crescent and Implications of the Recent Syrian Drought." Proceedings of the National Academy of Sciences of the United States of America 112 (11): 3241-3246.

Kiernan, B. 2008. The Pol Pot Regime: Race, Power, and Genocide in Cambodia under the Khmer Rouge, 1975-79, 3rd ed. New Haven: Yale University Press.

Lambers, W. 2015. "Ukraine War: Shelling and Hunger Killing Civilians." Huffington Post. Accessed July 11, 2015. http://huff.to/1JXvZH4.

Lowe, K. 2012. Savage Continent: Europe in the Aftermath of World War II. London: St. Martin's Press.

\section{M}

Mallory, W. H. 1926. China: Land of Famine. New York: American Geographical Society.

Malthus, T. 1798. An Essay on the Principle of Population. Reprinted. London: Macmillan, 1926.

Marcus, D. 2003. "Famine Crimes in International Law." The American Journal of International Law 97 (2): 245-281.

Martorell, R. 2008. Malnutrition and Hunger. Copenhagen Consensus 2008 Perspective Paper. Copenhagen Consensus Center. http://bit.ly/1QZzYd4.

Maxwell, D., and N. Majid. 2015. Famine in Somalia: Competing Imperatives, Collective Failures, 2011-12. London: Hurst.

Maystadt, J.-F., M. Calderone, and L. You. 2014. "Local Warming and Violent Conflict in North and South Sudan." Journal of Economic Geography. doi:10.1093/jeg//bu033.

Maystadt, J.-F., and O. Ecker. 2014. "Extreme Weather and Civil War: Does Drought Fuel Conflict in Somalia through Livestock Price Shocks?" American Journal of Agricultural Economics 96 (4): 1157-1182

Mazurana, D., A. Marshak, J. H. Opio, R. Gordon, and T. Atim. 2014. The Impact of Serious Crimes during the War on Households Today in Northern Uganda. Secure Livelihoods Research Consortium Briefing Paper 5. London: Overseas Development Institute.

McClelland, C., and M. Soque. 2015. "Hunger Causes World's Worst Child Death in Oil-Rich Angola." Bloomberg Business. Accessed May 10, 2015. http://bloom.bg/1zzACWS.

MEASURE DHS. 2015. Demographic and Health Surveys. Calverton, MD. Accessed May 22, 2015. www.dhsprogram.com.

Mongolia. 2013. Achieving the Millennium Development Goals. Fifth National Progress Report 2013. Accessed July 11, 2015. http://bit.ly/leRZy2k.

\section{N}

Natsios, A. 2001. The Great North Korean Famine: Famine, Politics and Foreign Policy. Washington, DC: US Institute of Peace Press.

Neely, S. 2007. A Concise History of the French Revolution. New York: Rowman and Littlefield.

Newman, L. F., ed. 1990. Hunger in History: Food Shortage, Poverty and Deprivation. Oxford: Blackwell.

0

O'Sullivan, M., A. Rao, R. Banerjee, K. Gulati, and M. Vinez. 2014. Levelling the Field: Improving Opportunities for Women Farmers in Africa. Washington, DC: World Bank Group. Accessed July 15, 2015. http://bit.ly/1jCf2Wh. 


\section{$\mathbf{P}$}

Pinker, S. 2012. The Better Angels of Our Nature: Why Violence Has Declined. London: Penguin.

PS21 (Project of the Study of the 21st Century). 2015. "Death Toll in 2014's Bloodiest Wars Sharply Up on Previous Year." Accessed May 18, 2015. http://bit.ly/1BWPFHG.

\section{$\mathbf{R}$}

Raleigh, C., and D. Kniverton. 2012. "Come Rain or Shine: An Analysis of Conflict and Climate Variability in East Africa." Journal of Peace Research 49 (1): 51-64.

Raleigh, C., A. Linke, and J. O'Loughlin. 2014. "Extreme Temperatures and Violence." Nature Climate Change 4: 76-77.

Rasella, D., R. Aquino, C. A. Santos, R. Paes-Sousa, and M. L. Barreto. 2013. "Effect of a Conditional Cash Transfer Programme on Childhood Mortality: A Nationwide Analysis of Brazilian Municipalities." The Lancet 382 (9886): 57-64.

Roaf, J., R. Atoyan, B. Joshi, K. Krogulski, and IMF (International Monetary Fund) staff team. 2014. 25 Years of Transition: Post-Communist Europe and the IMF. Regional Economics Issues Special Report. Accessed July 11, 2015. http://bit.ly/1Ho4Nk7.

Rocha, C. 2009. "Developments in National Policies for Food and Nutrition Security in Brazil." Development Policy Review 27 (1): 51-66.

\section{S}

Sachs, J. D., and A. M. Warner. 2001. "The Curse of Natural Resources." European Economic Review 45 (4): 827-838.

Sommer, A., and W. Mosley. 1972. "East Bengal Cyclone of November 1972: Epidemiological Approach to Disaster Assessment." The Lancet 299 (May 13): 1029-1036.

\section{$\mathrm{U}$}

Ukraine, Ministry of Economy. 2010. Millennium Development Goals: Ukraine 2010 Nationa Report. Accessed July 11, 2015. http://bit.ly/1eS27kU.

UNCTAD (United Nations Conference on Trade and Development). 2014. Economic Developmen in Africa Report 2014: Catalyzing Investment for Transformative Growth in Africa. Accessed July 15, 2015. http://bit.ly/1oJkAkn.

UNDP (United Nations Development Programme). 2012. Eradicate Extreme Hunger and Poverty: Where Are We? Accessed July 11, 2015. http://bit.ly/1JXTPpq.

2015. Rwanda 2014 National Human Development Report. Accessed July 9, 2015. http://bit.ly/1UQ2j4Z.

UNICEF. 1999. Results of the 1999 Iraq Child and Maternal Mortality Surveys: Preliminary Report. New York. http://bit.ly/1HS58cQ.

2009a. Childinfo: Nutritional Status (November 2009 update): Accessed June 14, 2015. http://data.unicef.org/nutrition/malnutrition.

2009b. Tracking Progress on Child and Maternal Nutrition: A Survival and Development Priority. Accessed on July 15, 2015. http://www.unicef.org/publications/files/Tracking_Progress _on_Child_and_Maternal_Nutrition_EN_110309.pdf.

2013. Childinfo: Nutritional Status (February 2013 update). Accessed March 26, 2014 www.childinfo.org/malnutrition_nutritional_status.php.

2015a. Childinfo: Multiple Indicator Cluster Surveys (MICS). Accessed May 21, 2015 www.childinfo.org/mics_available.html. 2015b. Malnutrition Current Status and Progress. Accessed on July 12, 2015. www .data.unicef.org/nutrition/malnutrition.

UNICEF/WHO (World Health Organization)/the World Bank. 2015. Levels and Trends in Child Malnutrition: UNICEF-WHO-The World Bank: Joint Malnutrition Estimates, June 2015. New York, Geneva, and Washington, DC. http://data.unicef.org/nutrition/malnutrition.

Urquhart, C. 2006. "Gaza on Brink of Implosion as Aid Cut-off Starts to Bite." The Guardian, April 15. www.theguardian.com/world/2006/apr/16/israel.

US Census Bureau. 2013a. World Population: Historical Estimates of World Population. Accessed May 26, 2015. http://1.usa.gov/1s8DBOV.

_. 2013b. World Population: Total Midyear Population for the World: 1950-2050. Accessed May 26, 2015. http://1.usa.gov/12jAHON.

US GAO (General Accountability Office). 2006. "Darfur Crisis: Death Estimates Demonstrate Severity of Crisis, but their Accuracy and Credibility Could be Enhanced." Report GAO-0724. Washington, DC.

USAID (United States Agency for International Development). 2014. "Ethiopia: Nutrition Profile." Accessed July 10, 2015. http://1.usa.gov/1LYUSVr.

\section{V}

von Braun, J., and T. Olofinbiyi. 2007. Famine and Food Insecurity in Ethiopia. Case Study 7-4 of the Program: Food Policy for Developing Countries: The Role of Government in the Global Food System, edited by P. Pinstrup-Andersen and F. Cheng. Ithaca, NY: Cornell University. http://bit.ly/1GYT4oo.

von Grebmer, K., H. Fritschel, B. Nestorova, T. Olofinbiyi, R. Pandya-Lorch, and Y. Yohannes. 2008. Global Hunger Index: The Challenge of Hunger 2008. Bonn, Washington, DC, and Dublin Deutsche Welthungerhilfe, International Food Policy Research Institute, and Concern Worldwide.

von Grebmer, K., B. Nestorova, A. Quisumbing, R. Fertziger, H. Fritschel, R. Pandya-Lorch, and Y. Yohannes. 2009. 2009 Global Hunger Index: The Challenge of Hunger: Focus on Financial Crisis and Gender Inequality. Bonn, Washington, DC, and Dublin: Deutsche Welthungerhilfe, International Food Policy Research Institute, and Concern Worldwide.

von Grebmer, K., M. T. Ruel, P. Menon, B. Nestorova, T. Olofinbiyi, H. Fritschel, Y. Yohannes, C. von Oppeln, O. Towey, K. Golden, and J. Thompson. 2010. 2010 Global Hunger Index The Challenge of Hunger: Focus on the Crisis of Child Undernutrition. Bonn, Washington, DC, and Dublin: Deutsche Welthungerhilfe, International Food Policy Research Institute, and Concern Worldwide.

von Grebmer, K., M. Torero, T. Olofinbiyi, H. Fritschel, D. Wiesmann, Y. Yohannes, L. Schofield, and C. von Oppeln. 2011. 2011 Global Hunger Index: The Challenge of Hunger: Taming Price Spikes and Excessive Food Price Volatility. Bonn, Washington, DC, and Dublin: Deutsche Welthungerhilfe, International Food Policy Research Institute, and Concern Worldwide.

von Grebmer, K., C. Ringler, M. W. Rosegrant, T. Olofinbiyi, D. Wiesmann, H. Fritschel, O. Badiane, M. Torero, Y. Yohannes, J. Thompson, C. von Oppeln, and J. Rahall. 2012. 2012 Global Hunger Index: The Challenge of Hunger: Ensuring Sustainable Food Security under Land, Water, and Energy Stresses. Bonn, Washington, DC, and Dublin: Welthungerhilfe, International Food Policy Research Institute, and Concern Worldwide.

von Grebmer, K., D. Headey, C. Béné, L. Haddad, T. Olofinbiyi, D. Wiesmann, H. Fritschel, S. Yin, Y. Yohannes, C. Foley, C. von Oppeln, and B. Iseli. 2013. 2013 Global Hunger Index: The Challenge of Hunger: Building Resilience to Achieve Food and Nutrition Security. Bonn, Washington, DC, and Dublin: Welthungerhilfe, International Food Policy Research Institute, and Concern Worldwide. 
von Grebmer, K., A. Saltzman, E. Birol, D. Wiesmann, N. Prasai, S. Yin, Y. Yohannes, P. Menon J. Thompson, A. Sonntag. 2014. 2014 Global Hunger Index: The Challenge of Hidden Hunger. Bonn, Washington, DC, and Dublin: Welthungerhilfe, International Food Policy Research Institute, and Concern Worldwide.

\section{W}

WFP (World Food Programme). 2015a. "Ukraine Crisis." Accessed July 12, 2015. www.wfp .org/ukraine-crisis.

_ 2015b. WFP Somalia Brief. http://bit.ly/1GYSelw.

Whiteside, A., and F. Henry. 2011. "The Impact of HIV and AIDS Research: A Case Study from Swaziland." Health Research Policy and Systems 9 (suppl 1): 1-9.

WHO (World Health Organization). 2013. World Malaria Report 2013. Accessed July 15, 2015 http://bit.ly/1MkLyv9.

2015. The WHO Global Database on Child Growth and Malnutrition. www.who.int /nutgrowthdb/en/.

Wiesmann, D. 2004. An International Nutrition Index: Concept and Analyses of Food Insecurity and Undernutrition at Country Levels. Development Economics and Policy Series 39. Frankfurt: Peter Lang.

2006a. 2006 Global Hunger Index: A Basis for Cross-Country Comparisons. Washington, DC: International Food Policy Research Institute.

2006b. A Global Hunger Index: Measurement Concept, Ranking of Countries, and Trends. Food Consumption and Nutrition Division Discussion Paper 212. Washington, DC International Food Policy Research Institute.
Wiesmann, D., H.-K. Biesalski, K. von Grebmer, and J. Bernstein. 2015. Methodological Review and Revision of the Global Hunger Index. ZEF Working Paper 139. Bonn: Zentrum für Entwicklungsforschung (Center for Development Research). http://www.zef.de/fileadmin /webfiles/downloads/zef_wp/zef_wp_139.pdf.

Wiesmann, D., J. von Braun, and T. Feldbrügge. 2000. An International Nutrition Index: Successes and Failures in Addressing Hunger and Malnutrition. ZEF Discussion Papers on Development Policy 26. Bonn: Zentrum für Entwicklungsforschung (ZEF).

Wiesmann, D., L. Weingärtner, and I. Schöninger. 2006. The Challenge of Hunger: Global Hunger Index: Facts, Determinants, and Trends. Bonn and Washington, DC: Deutsche Welthungerhilfe and International Food Policy Research Institute.

World Bank. 2011. World Development Report 2011: Conflict, Security and Development. Washington, DC.

_. 2015a. "Angola Overview: Economic Overview.” Accessed July 9, 2015. www.worldbank .org/en/country/angola/overview.

2015b. "Peru Country Overview." Accessed July 11, 2015. www.worldbank.org/en /country/peru/overview.

World Peace Foundation. 2015. "Mass Famine: The End of Mass Famine?" Accessed May 27. http://fletcher.tufts.edu/World-Peace-Foundation/Program/Research/How-Mass-Atrocities-End /Mass-Famine.

\section{$\mathbf{Z}$}

Zarni, M., with T. Taneja. 2015. "Burma's Struggle for Democracy: A Critical Appraisal." In Advocacy in Conflict: Critical Perspectives on Transnational Activism, edited by A. de Waal, 45-67. London: Zed Books. 


\section{PARTNERS}

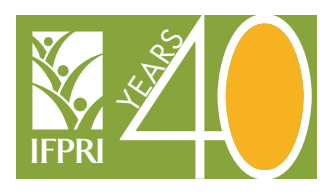

Who we are

The International Food Policy Research Institute (IFPRI) identifies and analyzes alternative strategies and policies for meeting the food needs of the developing world, with particular emphasis on low-income countries and on the poorer groups in those countries. It is celebrating its 40th year of providing evidence for policy solutions that sustainably reduce poverty and end hunger and malnutrition.

\section{What we do}

Our research focuses on six strategic areas: ensuring sustainable food production, promoting healthy food systems, improving markets and trade, transforming agriculture, building resilience, and strengthening institutions and governance.

\section{Our vision}

A world free of hunger and malnutrition.

\section{CONCERN}

Who we are

Founded in Ireland in 1968, Concern Worldwide is a nongovernmental, international, humanitarian organization dedicated to the reduction of suffering and working toward the ultimate elimination of extreme poverty. We work in 27 of the world's poorest countries, with offices in Ireland, the United Kingdom, the United States of America, and the Republic of Korea, and more than 2,900 committed and talented staff.

\section{What we do}

Our mission is to help people living in extreme poverty achieve major improvements which last and spread without ongoing support from Concern Worldwide. To this end, Concern Worldwide will work with the poor themselves, and with local and international partners who share our vision, to create just and peaceful societies where the poor can exercise their fundamental rights. To achieve this mission we engage in long-term development work, respond to emergency situations, and seek to address the root causes of poverty through our development education and advocacy work.

\section{Our vision}

A world where no one lives in poverty, fear or oppression; where all have access to a decent standard of living and the opportunities and choices essential to a long, healthy and creative life; a world where everyone is treated with dignity and respect.

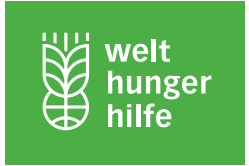

Who we are

Welthungerhilfe is one of the largest nongovernmental aid agencies in Germany. It was founded in 1962 under the umbrella of the Food and Agriculture Organization of the United Nations (FAO). At that time, it was the German section of the Freedom from Hunger Campaign, one of the first global initiatives to fight hunger.

\section{What we do}

We fight hunger and poverty. Our goal is to make ourselves redundant. We provide integrated aid: from rapid disaster aid to long-term development cooperation projects. We supported people in 41 countries through 385 overseas projects in 2014.

\section{How we work}

Help to self-help is our basic principle; it allows us to strengthen structures from the bottom up together with local partner organizations and ensures the long-term success of project work. In addition, we inform the public and take an advisory role with regard to national and international policy. This is how we fight to change the conditions that lead to hunger and poverty.

\section{Our vision}

A world in which all people can exercise their right to lead a selfdetermined life with dignity and justice, free from hunger and poverty. 


\section{YEARS OF TRACKING WORLD HUNGER}

Since 2006, the Global Hunger Index has been reporting on the state of hunger globally, by region, and by country

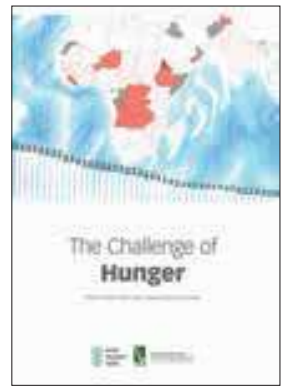

Case Studies in the PostConflict Countries of Afghanistan and Sierra Leone

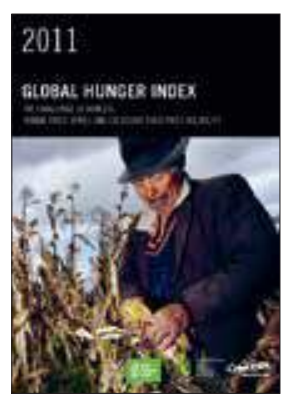

Taming Price Spikes and Excessive Food Price Volatility

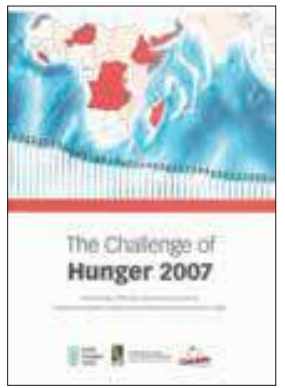

Measures Being Taken to Reduce Acute

Undernourishment and Chronic Hunger

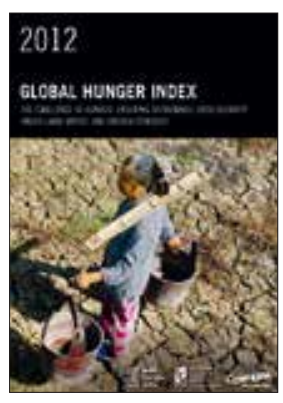

Ensuring Sustainable Food Security Under Land, Water, and Energy Stresses

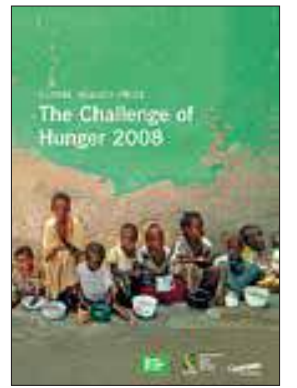

The Vicious Circle of Hunger and Poverty

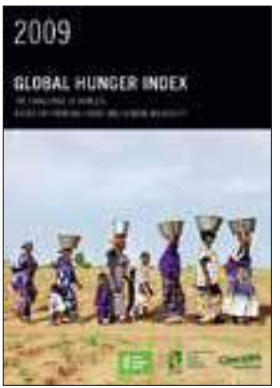

Financial Crisis and

Gender Inequality

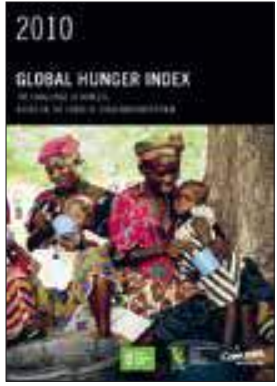

The Crisis of Child Undernutrition

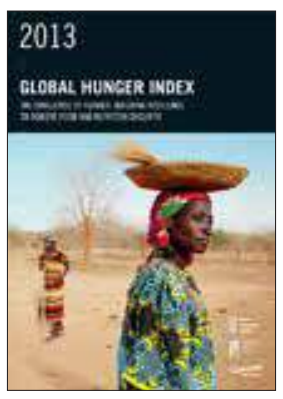

Building Resilience to Achieve Food and Nutrition Security

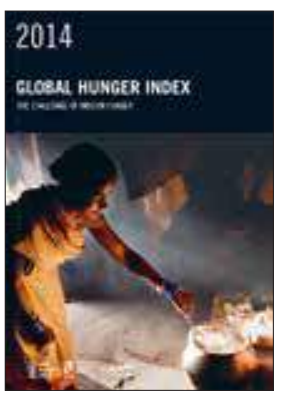

The Challenge of Hidden Hunger

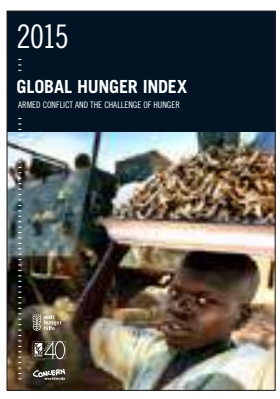

Armed Conflict and the Challenge of Hunger

For more information about the 2015 Global Hunger Index, visit www.ifpri.org/ghi/2015.

$\mathrm{GHI}$ resources for researchers and developers include:

$\rightarrow$ Interactive maps

$\rightarrow$ Dataverse data files

$\rightarrow$ Global Hunger Index Linked Open Data (LOD) available in both Resource Description Format (RDF) and Web Ontology Language (OWL) for reuse in new applications and analyses

$\rightarrow$ Global Hunger Index SPARQL Endpoint 


\section{IMPRINT}

Deutsche Welthungerhilfe e.V.

Friedrich-Ebert-Straße 1

53173 Bonn, Germany

Tel. +49 228-2288-0

Fax +49 228-2288-333

www.welthungerhilfe.de

\section{Secretary General and Chairperson:}

Dr. Till Wahnbaeck

\section{International Food Policy Research Institute (IFPRI)}

2033 K Street, NW

Washington, D.C. 20006-1002, USA

Tel. +1 202-862-5600

$\mathrm{Fax}+1$ 202-467-4439

www.ifpri.org

\section{Director General:}

Dr. Shenggen Fan

\section{Concern Worldwide}

52-55 Lower Camden Street

Dublin 2, Ireland

Tel. +353 1-417-7700

Fax +353 1-475-7362

www.concern.net

\section{Chief Executive:}

Dominic MacSorley

Editors: Andrea Sonntag (Senior Advisor Right to Food and Nutrition Policy, Welthungerhilfe), Larissa Neubauer (Policy and External Relations, Welthungerhilfe), Jennifer Thompson (Advocacy Officer for Hunger, Concern Worldwide), Olive Towey (Head of Advocacy, Ireland \& EU, Concern Worldwide), Klaus von Grebmer (Research Fellow Emeritus, IFPRI), Sandra Yin (Senior Editor, IFPRI)

Recommended citation: K. von Grebmer, J. Bernstein, A. de Waal, N. Prasai, S. Yin, and Y. Yohannes. 2015. 2015 Global Hunger Index: Armed Conflict and the Challenge of Hunger. Bonn, Washington, DC, and Dublin: Welthungerhilfe, International Food Policy Research Institute, and Concern Worldwide.

\section{Design: David Popham (Designer, IFPRI)}

FPO

FPC logo

goes here

Design development: muelhausmoers corporate communications gmbh, Cologne, Germany

Printing:

YGS
Authors:

International Food Policy Research Institute: Klaus von Grebmer (Research Fellow Emeritus), Jill Bernstein (Independent Consultant), Nilam Prasai (Data Curator), Sandra Yin (Senior Editor), Yisehac Yohannes (Research Analyst); World Peace Foundation/Tufts University: Alex de Waal (Executive Director/Research Professor)

\section{Ordering number:}

460-9494

\section{ISBN:}

978-0-89629-964-1

DOI:

http://dx.doi.org/10.2499/9780896299641

Photo credits:

Cover photography Panos/Sven Torfinn, 2003; page 2: Welthungerhilfe/Imke Lass, 2015; page 6: Welthungerhilfe/Roland Brockmann, 2014; page 12: Panos/Hossein Fatemi, 2013; page 22: Reuters/Esam Al-Fetori, 2011.

\section{Acknowledgments:}

Special thanks go to Doris Wiesmann (Independent Consultant), who spearheaded the development of the updated formula behind the Global Hunger Index. We also wish to recognize the external and internal formula reviewers, Hans Konrad Biesalski (Professor of Biological Chemistry and Nutritional Medicine, University of Hohenheim); Lawrence Haddad (Senior Research Fellow, IFPRI); Marie Ruel (Director of Poverty, Health, and Nutrition Division, IFPRI); and Harold Alderman (Senior Research Fellow, IFPRI). Special thanks go to Kelvin Pollard (Senior Demographer, Population Reference Bureau) for his advice on historical world population estimates. Thanks also go to IFPRI's Peer Review Committee, led by Gershon Feder, for reviewing this report.

\section{Disclaimer:}

The boundaries and names shown and the designations used on the maps herein do not imply official endorsement or acceptance by the International Food Policy Research Institute (IFPRI), Welthungerhilfe, or Concern Worldwide. 
To learn more, visit the 2015 GHI website at www.ifpri.org/ghi/2015

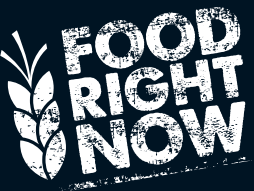

Food Right Now is an international education campaign run by Alliance 2015 .
Deutsche Welthungerhilfe e. V.

Friedrich-Ebert-Straße 1 53173 Bonn, Germany

Tel. +49 228-2288-0

Fax +49 228-2288-333

www.welthungerhilfe.de

Member of Alliance2015
International Food Policy

Research Institute

2033 K Street, NW

Washington, D.C. 20006-1002, USA

Tel. +1 202-862-5600

Fax +1 202-467-4439

www.ifpri.org

\section{Concern Worldwide}

52-55 Lower Camden Street Dublin 2, Ireland

Tel. +353 1-417-7700

Fax +353 1-475-7362

www.concern.net

Member of Alliance2015 